FATIMA RODRIGUES DE SOUSA E FREITAS

EFEITO DA REPOSIÇÃO DE HORMÔNIO DO CRESCIMENTO (GH) NO DESENVOLVIMENTO ÓSSEO EM RATAS HIPOTIREOIDEAS TRATADAS COM O AGONISTA SELETIVO DO RECEPTOR $\beta$ DE HORMÔNIO TIREOIDEANO, GC-1 
FATIMA RODRIGUES DE SOUSA E FREITAS

\section{EFEITO DA REPOSIÇÃO DE HORMÔNIO DO CRESCIMENTO (GH) NO DESENVOLVIMENTO ÓSSEO EM RATAS HIPOTIREOIDEAS TRATADAS COM O AGONISTA SELETIVO DO RECEPTOR $\beta$ DE HORMÔNIO TIREOIDEANO, GC-1}

Tese apresentada ao Instituto de Ciências Biomédicas da Universidade de São Paulo, para obtenção do Título de Doutor em Ciências (Ciências Morfofuncionais). 


\section{EFEITO DA REPOSIÇÃO DE HORMÔNIO DO CRESCIMENTO (GH) NO DESENVOLVIMENTO ÓSSEO EM RATAS HIPOTIREOIDEAS TRATADAS COM O AGONISTA SELETIVO DO RECEPTOR $\beta$ DE HORMÔNIO TIREOIDEANO, GC-1}

Tese apresentada ao Instituto de Ciências Biomédicas da Universidade de São Paulo, para obtenção do Título de Doutor em Ciências (Ciências Morfofuncionais).

Área de Concentração: Ciências Morfofuncionais

Orientadora: Profa. Dra. Cecília H. de A. Gouveia 


\section{LISTA DE FIGURAS}

Figura 1: Esquema das ações das selenodesiodases das iodotironinas.

Figura 2: Fórmula Estrutural do T3 e do GC-1

Figura 3: Esquema do teste de flexão de três pontos.

Figura 4: Curva Força-Deformação

Figura 5: Efeito do tratamento com T3, GC-1 e/ou GH nos níveis séricos de T4, T3 e IGF-I de ratas jovens hipotireoideas.

Figura 6: Efeito do tratamento com T3, GC-1 e/ou GH na variação do peso corporal de ratas jovens hipotireoideas.

Figura 7: Efeito do tratamento com T3, GC-1 e/ou GH no crescimento corporal longitudinal (comprimento final - comprimento inicial) de ratas jovens hipotireoideas

Figura 8: Efeito do tratamento com T3, GC-1 e/ou GH na variação de BMD ( $\triangle \mathrm{BMD}=\mathrm{BMD}$ final - BMD inicial) do corpo posterior de ratas jovens hipotireoideas

Figura 9: Efeito do tratamento com T3, GC-1 e/ou GH na variação de BMD ( $\triangle \mathrm{BMD}=\mathrm{BMD}$ final - BMD inicial) das vértebras lombares (L2-L5) de ratas jovens hipotireoideas.

Figura 10: Efeito do tratamento com T3, GC-1 e/ou GH na variação de BMD ( $\triangle \mathrm{BMD}=$ BMD final - BMD inicial) do fêmur, e suas regiões, de ratas jovens hipotireoideas

Figura 11: Efeito do tratamento com T3, GC-1 e/ou GH na variação de BMD ( $\triangle \mathrm{BMD}=$ BMD final - BMD inicial) da tíbia, e suas regiões, de ratas jovens hipotireoideas. .66

Figura 12: Efeito do tratamento com T3, GC-1 e/ou GH nos parâmetros biomecânicos da tíbia de ratas jovens hipotireoideas

Figura 13: Efeito do tratamento com T3, GC-1 e/ou GH na espessura da lâmina epifisial distal do fêmur de ratas jovens hipotireoideas. 
Figura 14: Efeito do tratamento com T3, GC-1 e/ou GH na área da lâmina epifisial distal do fêmur de ratas jovens hipotireoideas.

Figura 15: Efeito do tratamento com T3, GC-1 e/ou GH na morfometria da lâmina epifisial distal do fêmur de ratas jovens hipotireoideas

Figura 16: Efeito do tratamento com T3, GC-1 e/ou GH na lâmina epifisial de ratas hipotireoideas .73

Figura 17: Efeito do tratamento com T3, GC-1 e/ou GH no ganho de peso corporal de ratos neonatos hipotireoideos

Figura 18: Efeito do tratamento com T3 e GC-1 no comprimento corporal longitudinal.......75

Figura 19: Efeito do tratamento com T3, GC-1 e/ou GH no centro secundário de ossificação do fêmur de ratos neonatos hipotireoideos. .76

Figura 20: Efeito do tratamento com T3, GC-1 e/ou GH na ossificação endocondral do joelho direito (vista lateral) de ratos neonatos hipotireoideos.

Figura 21: Efeito do tratamento com T3, GC-1 e/ou GH na ossificação endocondral da pata posterior direita (vista dorsal) de ratos neonatos hipotireoideos. .78

Figura 22: Efeito do tratamento com T3, GC-1 e/ou GH na ossificação endocondral da pata anterior esquerda (vista dorsal) de ratos neonatos hipotireoideos.

Figura 23: Efeito do tratamento com T3, GC-1 e/ou GH na ossificação intramembranosa da fontículo posterior de ratos neonatos hipotireoideos. .80

Figura 24: Efeito do tratamento com T3, GC-1 e/ou GH na ossificação intramembranosa da fontículo posterior (vista lateral esquerda) em ratas hipotireoideas. 


\section{LISTA DE TABELAS}

Tabela 1: Tratamento das Ratas.

Tabela 2: Efeito do tratamento com T3 e/ou GH no Peso Corporal.........................................57

Tabela 3: Efeito do tratamento com GC-1 e/ou GH no peso corporal.....................................57 


\section{LISTA DE ABREVIATURAS E SIGLAS}

BMD: densidade mineral ósseo (bone mineral density)

CP: condrócitos proliferativos

CH: condrócitos hipertróficos

D1,-2,-3: selenodesiodase das iodotironinas (tipos 1,2,3)

DEXA: dual energy $x$-Ray absorptiometry

EDTA: disodium ethylene diamine tetra acetate

EPM: erro padrão da média

GH: hormônio do crescimento

GHBP: proteína de ligação ao hormônio do crescimento (growth hormone binding protein)

GHR: receptor do hormônio do crescimento

GHRH: hormônio liberador do hormônio do crescimento

IGFBP: proteína de ligação ao IGF-I (insulin-like growth factor protein-I)

IGF-I: fator de crescimento semelhante à insulina-I (insulin-like growth factor-I)

IGF-IR: receptor do IGF-I

PM: peso molecular

RTH: resistência ao hormônio tireoideano

T2: diiodotironina

T3: 3,5,3'-triiodotironina 
T3r: T3 reverso

T4: 3,5,3',5'-tetraiodotironina ou tiroxina

TR: receptor do hormônio tireoideano

TRE: elemento responsivo ao hormônio tireoideano

ZH: zona hipertrófica

ZP: zona proliferativa

LE: lâmina epifisial

ZR: zona de reserva 


\section{RESUMO}

Freitas FRS. Efeito da Reposição do Hormônio do Crescimento (GH) no Desenvolvimento Ósseo de Ratas Hipotireoideas Tratadas com o Agonista Seletivo do Receptor $\beta$ de Hormônio Tireoideano GC-1 [Tese (Doutorado em Ciências Morfofuncionais)]. São Paulo: Instituto de Ciências Biomédicas da Universidade de São Paulo; 2008.

O hormônio tireoideano (HT) exerce uma ampla variedade de efeitos no desenvolvimento e metabolismo do tecido ósseo. Sabe-se que a triiodotironina (T3) tem ações indiretas no esqueleto através da sua influência sobre a produção e secreção de hormônio do crescimento (GH)/insulin-like growth factor-1 (IGF-I) e/ou outros fatores. Por outro lado, ações diretas do T3 no esqueleto são amplamente aceitas apesar de pouco conhecidas. A maioria das ações do HT é mediada pelos seus receptores nucleares (TRs). As isoformas TR $\alpha 1$, TR $\beta 1$ e TR $\beta 2$ ligam T3, enquanto a isoforma TR 2 não liga e funciona, pelo menos in vitro, como antagonista da transcrição gênica mediada por TR $\alpha 1$ e TR $\beta 1$. Todos esses receptores, com exceção do TR $\beta 2$, são expressos nos condrócitos da lâmina epifisial, nos osteoblastos e osteoclastos. Entretanto, o papel de cada uma dessas isoformas de TR no desenvolvimento esquelético é pouco entendido. Há alguns anos, desenvolveu-se o GC-1, um análogo do T3 que apresenta alta afinidade e seletividade pelo TR $\beta 1 \mathrm{em}$ relação ao TR $\alpha 1$. Um estudo recente do nosso laboratório mostrou que o tratamento de ratas jovens hipotireoideas com T3 reverte a deficiência de IGF-I e defeitos esqueléticos causados pelo hipotireoidismo, enquanto que o tratamento com GC-1 não teve efeito sobre o IGF-I sérico ou sobre a expressão protéica de IGF-I nas lâminas epifisiais femorais, mas reverteu algumas das alterações esqueléticas decorrentes da deficiência de T3. Considerando-se a seletividade do GC-1 pelo TR $\beta$, esses achados sugerem que o T3 tem efeitos no desenvolvimento esquelético que são mediados pelo TR $\beta$ e independentes do eixo GH/IGF-I. Por outro lado, a incapacidade do GC-1 em reverter completamente as alterações no desenvolvimento ósseo levantou as seguintes hipóteses: (i) o desenvolvimento esquelético normal requer ações do T3 mediadas pelo TR $\alpha 1$ e TR $\beta 1$; ou (ii) requer ações sinérgicas ou aditivas entre o eixo GH/IGF-I e o HT. O presente estudo teve como objetivo investigar essas hipóteses. Para tanto, ratas recém desmamadas hipotireoideas foram tratadas com T3 ou GC-1 em associação ou não com o GH por 4 semanas. Os nossos achados mostram que o T3 e GH interagem para promover o crescimento longitudinal 
corporal, a diferenciação de condrócitos hipertróficas da lâmina epifisial, a ossificação intramembranosa dos ossos do crânio e o aumento da resistência óssea e de outros parâmetros biomecânicos que contribuem para uma melhor qualidade óssea. Por outro lado, os nossos resultados sugerem fortemente que o HT atua na aquisição de massa óssea, na organização dos condrócitos da lâmina epifisial e na ossificação endocondral prioritariamente de maneira independente do eixo GH/IGF-I e via TR $\alpha$ e/ou TR $\beta$.

Palavras-Chave: Hormônio tireoideano, Receptor de hormônio tireoideano, Hormônio do crescimento, IGF-I (insulin-like growth factor), Massa óssea, Resistência óssea, Desenvolvimento ósseo, Lâmina epifísial, Ossificação. 


\begin{abstract}
Freitas FRS. Effect of Growth Hormone (GH) Replacement in Bone Development of Hypothyroid Rats Treated with Thyroid Hormone Receptor-Beta Agonist, the GC-1 [Doutorate Thesis (Morfofunctional Science)]. São Paulo: Instituto de Ciências Biomédicas da Universidade de São Paulo; 2008.
\end{abstract}

Thyroid hormone (TH) has important effects on bone development and metabolism. It is known that triiodotyronine (T3) has indirect actions in the skeleton through its influence on the production and secretion of growth hormone $(\mathrm{GH}) /$ insulin-like growth factor (IGF-I) and/or other factors. On the other hand, direct actions of T3 on bone are recognized but not yet clear. Most of T3 action is mediaded by its nuclear receptors (TRs). TR $\alpha 1$, TR $\beta 1$ e TR $\beta 2$ bind T3, while TR $\alpha 2$ does not bind T3 and acts as an antagonist of genic transcription of TR $\alpha 1$ and TR $\beta 1$. All these receptors, except TR $\beta 2$, are expressed in chondrocytes of growth plate, osteoblasts and osteoclastos. However, the functional roles of each TR isoformas in the bone development are incompletely understood. A few years, it is development GC-1, a synthetic analog of T3 which is selective for TR $\beta 1$ over TR $\alpha 1$. In recent study, we showed that treatment of hypothyroid young rats with T3 revert the IGF-I deficiency and skeleton defects caused by hypothyroidism. Since GC-1 treatment does not effects on serum levels of IGF-I or protein expression of IGF-I in the growth plate, but revert some bone alterations induced by $\mathrm{T} 3$ deficiency. Considering the selectivity of GC-1 for TR $\beta$, these findings suggest that T3 has effects on bone development that are mediated by TR $\beta$ and independent of $\mathrm{GH} / \mathrm{IGF}-\mathrm{I}$ axis. On the other hand, the inability of GC-1 in completely revert the alterations of bone development suggests that the normal skeleton development require (i) T3 actions mediated by TR $\alpha 1$ and TR $\beta 1$, or (ii) synergic or additive actions between GH/IGF-I axis and thyroid hormone. To investigate these hypotheses, 21 day-old hypothyroid female rats were treated with T3 or GC-1 in association or not with GH for 4 weeks. Our findings show that T3 interacts with $\mathrm{GH}$ to promote body growth, differentiation of growth plate hypertrofic chondrocytes, intramembranous ossification of cranial bone, and increased of bone resistance and other biomechanics parameters that contribute to the best bone quality. On the other hand, ours results suggest strongly that $\mathrm{TH}$ acts in bone mass acquisition, in organization of growth 
plate chondrocytes and endocondral ossification mainly independent of GH/IGF-I axis and via $\operatorname{TR} \alpha$ and/or TR $\beta$.

Key Words: Thyroid hormone, Thyroid hormone receptors (TRs), Growth hormone, Insulinlike growth factor (IGF-I), Bone mass, Bone resistance, Bone development, Growth plate, Ossification. 


\section{SUMÁRIO}

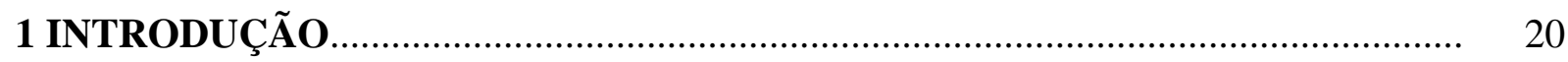

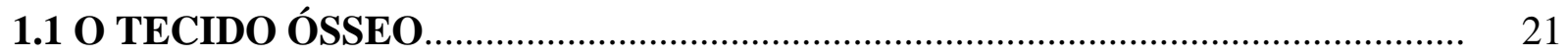

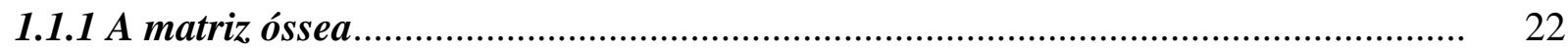

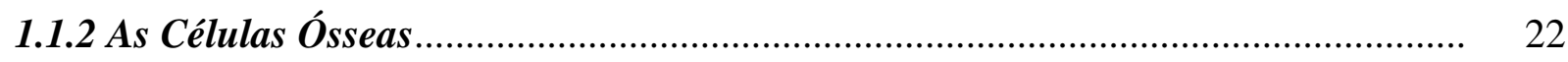

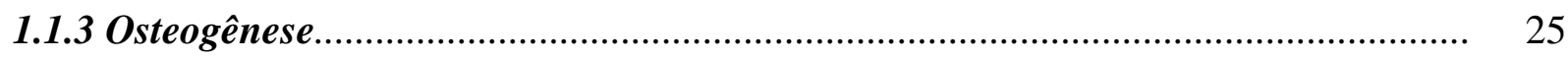

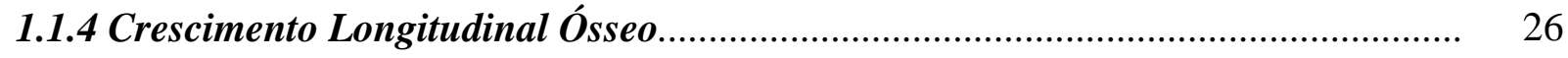

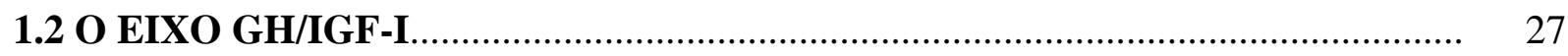

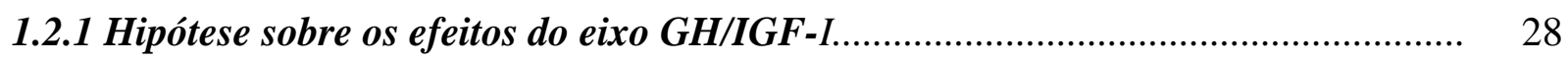

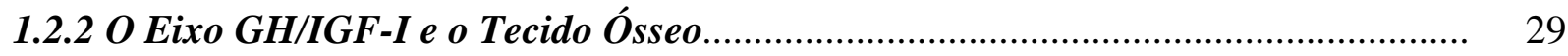

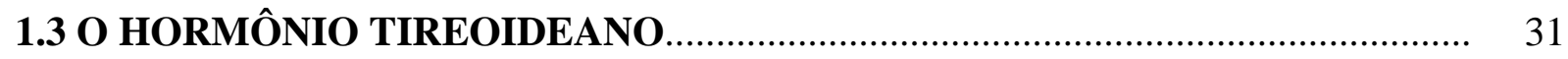

1.3.1 Receptores Nucleares do Hormônio Tireoideano...............................................

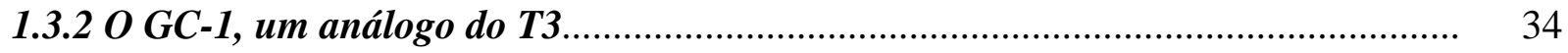

1.3.3 O Hormônio Tireoideano e o Tecido Ósseo........................................................... 36

1.3.4 Efeitos do Hormônio Tireoideano no Eixo GH/IGF-I......................................... 36

1.3.5 O Papel das Diferentes Isoformas de Receptores do Hormônio Tireoideano.......... 38

1.3.6 Efeitos Diretos versus Efeitos Indiretos do Hormônio Tireoideano no Esqueleto . $\quad 40$

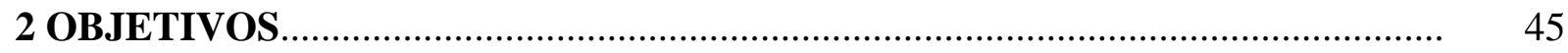

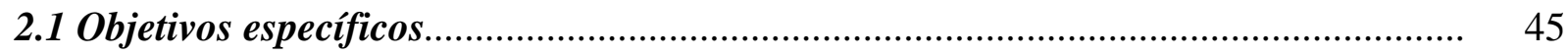

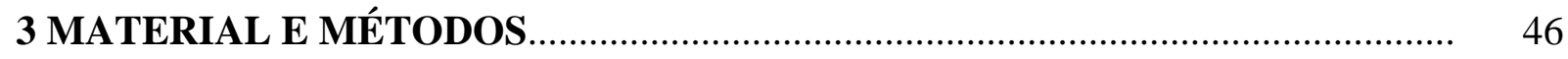

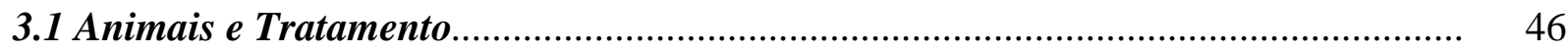




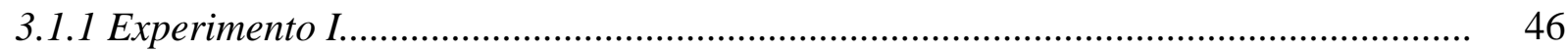

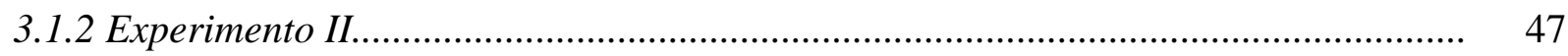

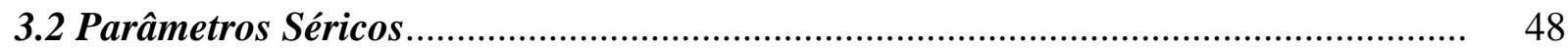

3.3 Medida da Massa Óssea por Densitometria Óssea.................................................. 48

3.4 Crescimento Corporal Longitudinal .............................................................. 50

3.5 Parâmetros Biomecânicos Ósseos...........................................................................

3.6 Histologia e Morfometria da Lâmina Epifisial........................................................

3.7 Análise do Processo de Ossificação - Preparação dos Esqueletos............................. 53

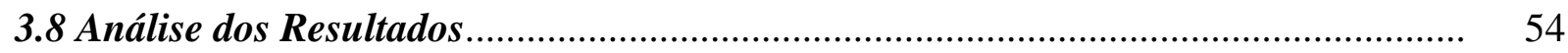

\section{RESULTADOS}

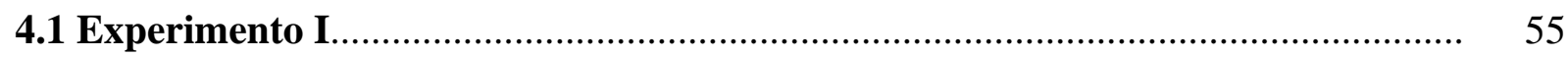

4.1.1 Níveis Séricos de T4, T3 e IGF-I...................................................................... 55

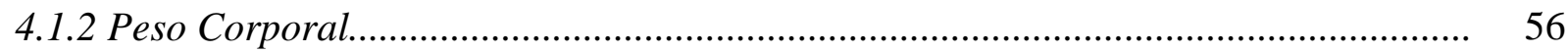

4.1.3 Crescimento Corporal Longitudinal................................................................ 60

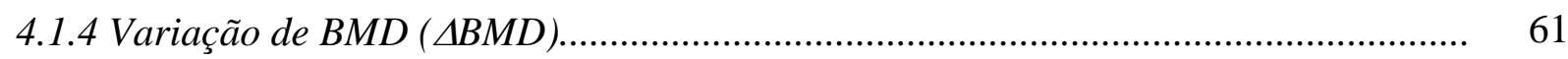

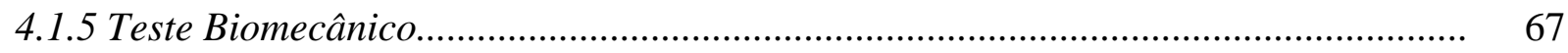

4.1.6 Histologia e Morfometria da Lâmina Epifisial........................................................ 69

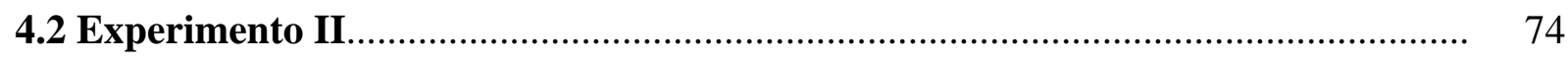

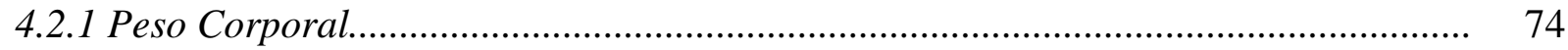

4.2.2 Comprimento Corporal Longitudinal............................................................... 74

4.2.3 Análise da Ossificação Endocondral e Intramembranosa........................................ 75

5 DISCUSSÃO 
6 CONCLUSÃO

REFERÊNCIAS BIBLIOGRÁFICAS............................................................ 92 


\section{INTRODUÇÃO}

O hormônio tireoideano exerce uma ampla variedade de efeitos no organismo, que vão desde ações no desenvolvimento embrionário e pós-natal, até a manutenção da taxa metabólica em adultos. O tecido ósseo é um importante alvo do hormônio tireoideano, sofrendo várias alterações em situações de excesso ou deficiência de triiodotironina (T3). Por exemplo, durante o desenvolvimento ósseo, o hipertireoidismo resulta em maturação esquelética acelerada e diminuição do crescimento (Allain e McGregor, 1993; Harvey et al., 2002; O'Shea et al., 2003). Por outro lado, a deficiência de T3 provoca atraso na ossificação e desorganização da lâmina epifisial, resultando em redução do crescimento e anomalias esqueléticas (Allain e McGregor, 1993; Lewinson et al., 1989).

Embora a importância do hormônio tireoideano no desenvolvimento e metabolismo ósseos seja clara, ainda é pouco o que se sabe sobre os mecanismos que medeiam os efeitos desse hormônio no tecido ósseo. Sabe-se que o hormônio tireoideano pode agir de maneira direta ou indireta no esqueleto. Acredita-se que grande parte das suas ações diretas seja mediada por receptores nucleares de hormônio tireoideano, os TRs. Existem quatro isoformas clássicas de TRs, o TR $\alpha 1$, TR $\alpha 2$, TR $\beta 1$ e TR $\beta 2$. A identificação das isoformas TR $\alpha 1$, TR $\alpha 2$ e TRß1 nas células ósseas, osteoblastos e osteoclastos, e nos condrócitos da lâmina epifisial, assim como a responsividade dessas células ao T3 em culturas isoladas (Abu et al., 1997; Williams, Bland e Sheppard, 1994), evidenciam a ação direta do T3 no tecido ósseo, contudo a importância funcional das diferentes isoformas de TR no esqueleto é ainda é pouco conhecida.

O hormônio tireoideano também age no tecido ósseo indiretamente, através do eixo hormônio do crescimento/fator de crescimento insulin-like I (GH/IGF-I). A transcrição do gene do GH é estimulada pelo T3, o que faz com que o hipotireoidismo seja acompanho de uma menor atividade do eixo GH/IGF-I (Nanto-Salonen et al., 1993). Sabe-se que o tanto o GH quanto o IGF-I apresentam efeitos importantes no tecido ósseo, tais como a indução da proliferação e diferenciação dos condrócitos da lâmina epifisial (Gevers et al., 2002) e dos osteoblastos (Barnard et al., 1991), regulando assim o crescimento e a massa óssea.

Dessa forma, uma questão ainda sem resposta é se os efeitos do T3 no tecido ósseo são predominantemente diretos, mediados pelos seus receptores nucleares, ou se são 
primariamente resultado da sua interação com o eixo GH/IGF-I. Resultados anteriores do nosso laboratório mostraram que, em ratas hipotireoideas, o tratamento com T3 reverte as alterações esqueléticas causadas pelo hipotireoidismo, como a diminuição da massa óssea e o defeito na ossificação e na morfologia da lâmina epifisial. Por outro lado, o tratamento com GC-1, um análogo do T3 seletivo pelo TR $\beta$, resultou em efeitos apenas parciais, além de não elevar os níveis séricos de IGF-I e não induzir a expressão protéica de IGF-I na lâmina epifisial (Freitas et al., 2005). Esses resultados sugerem fortemente que o hormônio tireoideano exerce efeitos no desenvolvimento ósseo mediados pelo TR $\beta$ independentes do eixo GH/IGF-I. Contudo, a incapacidade do GC-1 em reverter completamente os defeitos do esqueleto decorrentes do hipotireoidismo sugere que algumas ações do hormônio tireoideano são mediadas pelo TR $\alpha 1$ e/ou são ações dependentes do eixo GH/IGF-I.

Assim sendo, no presente estudo, tivemos como objetivo investigar essas questões tratando ratas jovens hipotireoideas com GC-1 em associação ou não com o GH, e avaliando uma série de parâmetros do desenvolvimento esquelético desses animais.

\subsection{O TECIDO ÓSSEO}

O tecido ósseo é um tecido conjuntivo especializado que, juntamente com os tecidos cartilaginoso, hematopoiético e adiposo, além de vasos sangüíneos e nervos, compõe um osso. Os ossos realizam funções mecânicas de sustentação e de proteção dos órgãos, além de compor um sistema de alavancas para os movimentos do corpo. Somando-se a isso, os ossos apresentam funções de hematopoiese e de homeostase mineral, e ainda servem como depósito de minerais e gordura (Baron, 2003).

De acordo com sua estrutura, o osso pode ser classificado como cortical (ou compacto) e trabecular (ou esponjoso). Embora os elementos constituintes sejam os mesmos nos dois tipos de osso, a substância óssea dispõe-se diferentemente conforme o tipo considerado. O osso cortical se organiza de forma compacta e está presente predominantemente nos ossos longos. O osso cortical corresponde a aproximadamente $80 \%$ da massa esquelética total, além de apresentar uma importância fundamental na resistência 
óssea. Já o osso trabecular, que corresponde a $20 \%$ da massa esquelética, se organiza na forma de traves ou trabéculas ósseas interconectadas entre si, compondo a substância esponjosa. O osso trabecular é encontrado predominantemente no esqueleto axial e nas extremidades dos ossos longos. A substância esponjosa proporciona resistência adicional aos ossos, além de acomodar a medula óssea por entre as suas traves ósseas (Baron, 2003).

O tecido ósseo, assim como todo tecido conjuntivo, é constituído por um componente celular e por uma ampla matriz extracelular.

\subsubsection{A matriz óssea}

No osso maduro, a matriz extracelular é constituída por aproximadamente $35 \%$ de material orgânico e por $65 \%$ de material inorgânico. A fase orgânica da matriz óssea é formada por proteínas colágenas, com predomínio de colágeno do tipo I, e proteínas nãocolágenas. Essas, intimamente relacionadas às proteínas colágenas, são divididas em quatro grupos principais: proteoglicanas (decorin e biglican), glicoproteínas (osteonectina e fosfatase alcalina), glicoproteínas de adesão (osteopontina, sialoproteina óssea), e proteínas $\gamma$ carboxilada (osteocalcina). Essas proteínas, além de serem responsáveis pela mineralização da matriz, por apresentarem sítios de ligação aos íons, também apresentam funções na proliferação e diferenciação celular (Robey e Boskey, 2003). A fase inorgânica da matriz óssea é constituída predominantemente por íons de cálcio e fósforo, que se fundem formando estruturas cristalinas, similares aos cristais de hidroxiapatita $\left[\mathrm{Ca}_{10}\left(\mathrm{PO}_{4}\right)_{6}(\mathrm{OH})_{2}\right]$, e, por sua vez, são depositados ao longo de uma estrutura tridimensional formada pelas proteínas da fase orgânica, durante o processo de mineralização da matriz (Robey e Boskey, 2003).

\subsubsection{As células ósseas}

As células ósseas representam apenas 1 a $2 \%$ do tecido ósseo, entretanto, são responsáveis pelo metabolismo ósseo. As principais células ósseas são: os (i) osteoclastos, responsáveis pela reabsorção óssea; (ii) osteoblastos, responsáveis pela formação óssea; (iii) osteócitos, encontrados embebidos na matriz extracelular; e as (iv) células de revestimento, responsáveis pela proteção das superfícies ósseas (Baron, 2003; Franz-Odendall, Hall e Witten, 2006). 
Os osteoclastos são células multinucleadas gigantes, derivadas de uma linhagem de células progenitoras de monócitos/macrófagos, que se encontra presente no sangue e na medula óssea. Os osteoclastos são encontrados em contato íntimo com a superfície óssea em depressões denominadas lacunas de reabsorção, também chamada de lacunas de Howship, que são resultado da sua atividade reabsortiva. A região de contato do osteoclasto com o osso é caracterizada por uma borda em escova, rodeada por uma área citoplasmática livre de organelas, porém com abundância de proteínas contráteis que participam da ligação do osteoclasto à superfície do osso, formando uma zona selada. A zona selada, a borda em escova e a superfície óssea formam um compartimento extracelular fechado de reabsorção, que é acidificado pela secreção de íons de hidrogênio através de bombas de prótons presentes na borda em escova. A reabsorção óssea ocorre em função do $\mathrm{pH}$ baixo, o que causa dissolução dos cristais de hidroxiapatita e expõe a matriz óssea. Em seguida, as enzimas lisossomais dos osteoclastos degradam os componentes orgânicos da matriz e formam as lacunas de Howship.

A formação de osso é realizada pelos osteoblastos. Essas células se originam de células mesenquimais, que se diferenciam em células pré-osteoblásticas, que, por sua vez, são células comprometidas a se diferenciarem em osteoblastos. As células pré-osteoblásticas encontram-se próximas aos osteoblastos ativos no periósteo e endósteo. Os osteoblastos são células cubóides, mononucleadas e formam uma única camada que recobre todos os locais ativos de formação óssea. Os osteoblastos são responsáveis pela síntese, deposição e mineralização da matriz óssea. A matriz óssea recém-formada, adjacente aos osteoblastos ativos e ainda não calcificada, recebe o nome de osteóide. Os osteoblastos também exercem um papel importante, embora indireto, na regulação da reabsorção do osso, uma vez que são essas células, e não os osteoclastos, que possuem receptores para a maioria dos fatores que induzem a reabsorção óssea, como por exemplo, o hormônio da paratireóide (PTH). Para isso, os osteoblastos liberam fatores de acoplamento, como por exemplo, o ligante do ativador do receptor do fator nuclear $\mathrm{\kappa B}$ (RANKL, do inglês receptor activator of nuclear factor kappa $B$ ligand), que ativam os osteoclastos. Além disso, os osteoblastos sintetizam e depositam fatores de crescimento na matriz óssea, como o IGF-I, que, posteriormente, serão liberados no processo de reabsorção óssea e atuarão sobre os próprios osteoblastos. Assim sendo, os osteoblastos exercem um papel central no metabolismo e fisiologia ósseos, uma vez que sintetizam a matriz extracelular, controlam a sua mineralização e comandam a reabsorção óssea. 
À medida que a atividade osteoblástica de formação óssea prossegue, algumas dessas células podem se tornar encarceradas pelo seu próprio produto (a matriz óssea). Uma vez embebidos na matriz óssea, os osteoblastos sofrem mudanças morfológicas e metabólicas e, então, são chamados de osteócitos. Estas células estão localizadas em lacunas na matriz óssea, das quais partem canalículos onde estão situados prolongamentos citoplasmáticos dos osteócitos, que os mantêm em contato com outros osteócitos, com osteoblastos e com as células de revestimento encontradas nas superfícies ósseas, compondo uma extensa rede funcional. Ainda não são claras as funções dos osteócitos, porém, existem evidências de que eles têm um papel essencial na manutenção da integridade da matriz óssea, já que podem atuar como sensores da condição mecânica e química da matriz óssea e que, por meio de suas comunicações com as células de revestimento, podem ativar o remodelamento ósseo (Knothe Tate et al., 2004). Acredita-se, ainda, que os osteócitos apresentam habilidade de depositar e reabsorver osso ao redor de suas lacunas, mudando a forma dessas lacunas.

Um outro grupo importante de células presentes no tecido ósseo são as células de revestimento. Essas células são encontradas em todas as superfícies ósseas quiescentes, ou seja, onde não está ocorrendo formação ou reabsorção óssea. Há evidências de que essas células sejam osteoblastos inativos que podem voltar ao estado ativo quando estimuladas apropriadamente. Elas formam camadas contínuas e estão em contato umas com as outras e com os osteócitos, através de junções celulares. Sua função ainda não é clara, mas acredita-se que essas células atuem no sentido de proteger as superfícies ósseas de agentes nocivos à integridade óssea, como por exemplo os pirofosfatos. Acredita-se, ainda, que essas células exerçam um papel ativo na regulação da diferenciação das células osteoprogenitoras. Além disso, essas células possuem receptores de hormônios e fatores que iniciam o remodelamento ósseo (Franz-Odendall, Hall e Witten, 2006).

Nota-se, portanto, que os osteoblastos podem ter três destinos diferentes no final da fase de formação óssea: (1) tornar-se encarcerado pela matriz óssea e transformar-se em um osteócitos, (2) tornar-se uma célula de revestimento ou (3) sofrer apoptose. A proporção de osteoblastos que segue cada destino não é a mesma para todos os mamíferos e variam com o tipo de osso e a idade do individuo. 


\subsubsection{Osteogênese}

O tecido ósseo é formado ou pelo processo chamado de ossificação intramembranosa, ou pelo processo de ossificação endocondral.

A ossificação intramembranosa ocorre no interior de uma membrana conjuntiva. Esse processo de ossificação inicia-se pela condensação de células mesenquimais e posterior vascularização dessa condensação celular, constituindo uma membrana. Em seguida, células mesenquimais da membrana se diferenciam em osteoblastos, os quais começam a sintetizar matriz óssea. Essa matriz é, então, mineralizada, constituindo um centro primário de ossificação. Os vários centros de ossificação crescem radialmente, substituindo a membrana conjuntiva inicial por osso.

O processo de ossificação endocondral tem início sobre um molde de cartilagem hialina. Na formação dos ossos longos, o molde cartilaginoso possui uma parte média estreita e as extremidades dilatadas, correspondendo à diáfise e epífises, respectivamente. $\mathrm{O}$ primeiro tecido ósseo a aparecer é formado por ossificação intramembranosa, a partir do pericôndrio, que reveste a parte média da diáfise, formando um cilindro, chamado de colar ósseo. Enquanto o colar ósseo é formado, os condrócitos por ele envolvidos sofrem multiplicação, hipertrofia, induzem a mineralização da matriz cartilaginosa e sofrem apoptose. Vasos sangüíneos atravessam o colar ósseo, levando células osteoprogenitoras, que se proliferam e se diferenciam em osteoblastos. Estes formam camadas contínuas nas superfícies das traves cartilaginosas calcificadas e iniciam a síntese da matriz óssea que logo se mineraliza. Formase, assim, o tecido ósseo sobre as traves, o que compõe a esponjosa primária. Esse centro de ossificação, que aparece na parte média da diáfise, é chamado de centro primário de ossificação. Seu crescimento rápido, em sentido longitudinal, acaba por ocupar toda a diáfise. No início da formação do centro primário de ossificação, surgem osteoclastos, que reabsorvem o tecido ósseo formado no centro da cartilagem, formando assim, o canal medular. À medida que o canal medular é formado, ele vai sendo ocupado por medula óssea, que dará origem às células sangüíneas e osteoprogenitoras. Mais tarde, formam-se os centros de ossificação secundários, um em cada epífise. Estes centros são semelhantes ao centro primário, mas seu crescimento é radial em vez de longitudinal. A porção central do osso formado nos centros secundários também contém medula óssea. Quando o tecido ósseo formado nos centros secundários de ossificação ocupa a epífise, o tecido cartilaginoso fica 
reduzido a uma lâmina epifisial, entre a diáfise e epífise, que será responsável, de agora em diante, pelo crescimento longitudinal do osso.

\subsubsection{Crescimento Longitudinal Ósseo}

O crescimento longitudinal ósseo é resultado de uma série de processos que ocorrem nas lâminas epifísiais, incluindo a proliferação e diferenciação dos condrócitos e a ossificação endocondral.

A lâmina epifisial (LE) é uma estrutura cartilaginosa altamente organizada (Van Der Eerden, Karperien e Wit, 2003). Ela pode ser dividida em zonas horizontais de condrócitos em diferentes estágios de diferenciação: zona de reserva, zona proliferativa, zona préhipertrófica e zona hipertrófica (Van Der Eerden, Karperien e Wit, 2003). A zona de reserva contém condrócitos dispersos na matriz extracelular. Essas células parecem ser cruciais para a orientação das colunas de condrócitos na zona proliferativa, e conseqüente crescimento ósseo unidirecional. Por um estímulo ainda não conhecido, os condrócitos da zona de reserva sofrem divisões na direção longitudinal e se organizam em colunas, formando a zona proliferativa. Os condrócitos proliferativos sintetizam uma grande quantidade de proteínas da matriz extracelular, que são essenciais para a estrutura da LE. Num dado momento, em função de um número definido de divisões ou em função da exposição a determinados fatores, os condrócitos proliferativos perdem sua capacidade de divisão, começam a se diferenciar e sofrem hipertrofia, tornando-se pré-hipertróficos. Os condrócitos pré-hipertróficos localizamse em uma região chamada de zona pré-hipertrófica. Em seguida, estas células se diferenciam em condrócitos hipertróficos, formando a zona hipertrófica. Este estágio é caracterizado por um aumento da concentração intracelular de cálcio, que é essencial para a produção de vesículas de matriz, que são liberadas pelos condrócitos. Essas vesículas liberam hidroxiapatita e metaloproteinases de matriz, resultando na mineralização da matriz ao redor da vesícula. Este processo de mineralização atrai vasos sangüíneos. Em seguida, os condrócitos hipertróficos sofrem apoptose, deixando um suporte para a formação de osso. Os septos deixados pelos condrócitos são reabsorvidos pelos osteoclastos. Ao mesmo tempo, osteoblastos vindo da circulação sangüínea entram nesta área e, então, começa a formação de novo osso. A combinação da proliferação e maturação dos condrócitos e da produção de matriz extracelular são os maiores contribuintes para o crescimento longitudinal ósseo. 


\subsection{O EIXO GH/IGF-I}

O hormônio do crescimento $(\mathrm{GH})$ é um importante regulador sistêmico do crescimento longitudinal e metabolismo ósseos, devido aos seus efeitos nos condrócitos da lâmina epifisial, nos osteoblastos e osteoclastos.

O GH é um hormônio peptídico de cadeia simples, secretado de maneira pulsátil pelas células somatotróficas localizadas na hipófise anterior. Sua secreção é regulada por dois hormônios hipotalâmicos, o hormônio liberador de GH (GHRH), que é um regulador positivo, e a somatostatina, um regulador negativo (Ueland, 2004).

Os efeitos do GH são mediados por duas proteínas, o receptor de GH (GHR) e a proteína de ligação ao hormônio do crescimento (GHBP - Growth Hormone Binding Protein). O GHR é uma proteína transmembrânica que se liga ao GH com alta afinidade e especificidade, sendo que a sua expressão é necessária para a responsividade celular ao hormônio. O transcrito primário do RNAm do GHR pode sofrer splicing alternativo formando a GHBP (Leung et al., 1987). Essa consiste de um domínio de ligação ao ligante, que é idêntico à porção extracelular do GHR, e um domínio C-terminal hidrofílico, ao invés dos domínios intracelular e transmembrânico do GHR (Edens e Talamantes, 1998). A GHBP pode capturar o GH livre, impedindo sua ligação ao receptor, protegendo, dessa forma, a célula de exposição contínua ao GH (Gevers et al., 2002). Tanto o GHR quanto a GHBP são expressos em vários tecidos, como o fígado, coração, rim, músculos, hipófise e também nas células ósseas e condrócitos da lâmina epifisial (Carlsson et al., 1990; Gevers et al., 2002).

Apesar dos efeitos diretos do GH mediados pelo GHR em inúmeros tecidos, o principal local de ação do GH é o fígado, onde estimula a produção do fator de crescimento semelhante à insulina do tipo I (IGF- I, insulin-like growth factor- I). Embora o principal local de produção de IGF-I seja o fígado, esse peptídeo mitogênico é expresso em vários outros tecidos, onde suas ações endócrina, parácrina e autócrina são mediadas pela sua ligação ao seu receptor, o IGF-IR.

Assim como o GH, o IGF-I na circulação sangüínea liga-se com alta afinidade a proteínas de ligação ao IGF, as IGFBPs (IGF binding proteins), que atuam como proteínas carreadoras (Olney, 2003; Ueland, 2004). As IGFBPs regulam a atividade do IGF-I, protegendo-o contra a degradação proteolítica e controlando a disponibilidade de IGF-I nos 
tecidos alvo (Firth e Baxter, 2002). São conhecidos 6 tipos de IGFBPs, sendo as mais importantes para o tecido ósseo, as -3, -4 e -5 (Olney, 2003; Ueland, 2004). A IGFBP-3 bloqueia os efeitos do IGF-I nos osteoblastos, por ligar e seqüestrar este fator de crescimento (Schmid et al., 1991). Já a IGFBP-4 inibe as ações do IGF-I impedindo sua ligação ao IGF-IR (Mohan et al., 1995). A IGFBP-5 é a proteína de ligação ao IGF-I mais importante para o osso, pois, devido à sua alta afinidade à hidroxiapatita, pode agir na fixação do IGF-I na matriz óssea (Campbell e Andress, 1997; Schmid et al., 1996).

\subsubsection{Hipóteses sobre os Efeitos do Eixo GH/IGF-I}

Os estudos sobre os efeitos do GH e IGF-I começaram há mais de meio século. Na época, foi demonstrado que a injeção de $\mathrm{GH}$ em ratos hipofisectomizados restaurava a incorporação de ${ }^{35} \mathrm{SO}_{4}$ pela cartilagem epifisária, que estava diminuída após a hipofisectomia (Murphy, Daughaday e Hartnett, 1956; Salmon e Daughaday, 1957). Entretanto, quando células da cartilagem costal foram tratadas com GH em cultura, não foi observado nenhum efeito, sugerindo que o efeito do GH, observado na cartilagem in vivo, era indireto, mediado por uma substância circulante (Daughaday e Reeder, 1966), posteriormente chamada de somatomedina (Daughaday et al., 1972). A partir desses estudos, postulou-se a Hipótese da Somatomedina, que sugere que o crescimento corporal é regulado pela ação da somatomedina, secretada pelo fígado em resposta ao estímulo do GH neste órgão. Mais tarde, o termo somatomedina foi alterado para insulin-like growth factor (IGF), após a determinação da sua estrutura primária (Rinderknecht e Humbel, 1978).

Já na década de 80, a Hipótese da Somatomedina começou a sofrer mudanças com estudos mostrando que células de diferentes tecidos de fetos de camundongos, como fígado, intestino, coração, cérebro e membro posterior, cultivadas em meio sem soro, apresentavam alto nível de IGF-I no meio de cultura (D'Ercole, Applewhite e Underwood, 1980). Como o GH é o principal regulador do IGF-I hepático, suspeitou-se que o GH também regularia a produção de IGF-I em outros tecidos, além do fígado. De fato, viu-se que a administração de GH em ratos hipofisectomizados aumentou a expressão gênica de IGF-I, não somente no fígado, mas também em outros tecidos, como pulmão, rim, músculo esquelético, coração e tecido adiposo branco (Lowe et al., 1987, 1988). Todos estes resultados indicam que o IGF-I é produzido localmente em vários tecidos, onde sua expressão pode ser regulada pelo GH e/ou outros hormônios. 
Em adição a esses dados, Green, Morikawa e Nixon (1985) evidenciaram que, em cultura de pré-adipócitos, o GH estimula as células progenitoras, enquanto que o IGF-I estimula a subseqüente expansão clonal. Assim foi postulada a "Teoria do Duplo Efeito", que supõe que o GH e IGF-I estimulam as células em diferentes estágios de maturação. Esta hipótese foi confirmada nas células da lâmina epifisial de ratos. Ohlsson et al. (1992) demonstraram que a injeção local de GH, ao contrário do IGF-I, estimulou a incorporação de timidina radioativa pelos condrócitos da zona de reserva da lâmina epifisial de tíbias de ratos hipofisectomizados.

Mais recentemente, estudos com animais com deleção (animais knockout) ou com superexpressão dos genes de GH e/ou IGF-I têm trazido grande contribuição para o entendimento do papel de cada um desses hormônios no desenvolvimento esquelético. Camundongos com deleção do gene do IGF-I, apesar de apresentarem altos níveis séricos de GH, apresentam retardo no crescimento, o que sugere que o IGF-I tem efeitos diretos no crescimento longitudinal ósseo (Woods et al., 1996). Corroborando com estes dados, Lupu et al. (2001) mostraram que animais com duplo knockout para GHR e IGF-I apresentam retardo no crescimento mais severo do que os animais com simples knockout de GHR e IGF-I.

Assim sendo, Le Roith et al. postularam uma nova hipótese sobre os efeitos do eixo GH/IGF-I, a qual sugere que GH apresenta efeitos indiretos através da regulação do IGF-I hepático e local, mas também tem efeitos diretos independentes do IGF-I. O mesmo ocorre com o IGF-I que apresenta efeitos dependentes e independentes do GH (Le Roith et al., 2001).

\subsubsection{O Eixo GH/IGF-I e o Tecido Ósseo}

Os vários componentes do sistema GH/IGF são expressos em vários tecidos. Através de suas ações endócrina/parácrina/autócrina, eles promovem uma complexa regulação do metabolismo celular.

Gevers et al. (2002) mostraram a expressão de GHR e GHBP nos condrócitos da lâmina epifisial de ratos adultos. A expressão de GHR nos condrócitos proliferativos sugere que o GH apresenta efeitos diretos não somente na zona de reserva, como postulado por outros autores (Ohlsson et al., 1992), seguindo a Teoria do Duplo Efeito, mas também na proliferação e maturação dos condrócitos. Em ratos de 12 semanas de idade, a localização de 
GHR e GHBP na zona pré-hipertrófica da lâmina epifisial é visível, enquanto que esta marcação desaparece nos condrócitos proliferativos. Essa diferença entre a marcação de GHR e GHBP nos condrócitos proliferativos e pré-hipertróficos indica que a sinalização do GHR está envolvida no processo de maturação dos condrócitos da lâmina epifisial (Gevers et al., 2002).

A expressão de IGF-IR e GHR funcionais, mediando efeitos na proliferação e diferenciação, também tem sido descrita em cultura de células osteoblásticas de humanos (Scheven et al., 1991), ratos (Barnard et al., 1991) e camundongos (Slootweg et al., 1996), sugerindo que ambos GH e IGF-I exercem efeitos diretos nos osteoblastos.

Além disso, estudos com animais com deleção ou superexpressão de genes também têm sido utilizados para investigar os efeitos do GH e IGF-I no tecido ósseo. Foi mostrado que, enquanto camundongos com superexpressão sistêmica de GH apresentam crescimento aproximadamente duas vezes maior do que animais selvagens (Palmiter et al., 1982), camundongos com superexpressão de IGF-I, e com deficiência na expressão de GH, demonstram crescimento longitudinal ósseo maior do que os animais transgênicos deficientes de GH, todavia, semelhante ao dos animais selvagens (Behringer et al., 1990), demonstrando que a superexpressão de GH, mas não de IGF-I, causa crescimento supranormal.

Camundongos com deleção do gene de IGF-I mostram severo retardo no crescimento, que é notável a partir do $12^{\circ}$ dia de vida embrionário, persistindo durante o período pós-natal. Além disso, estes animais apresentam lâmina epifisial com condrócitos menores (Liu et al., 1993; Powell-Braxton et al., 1993). Já os animais com knockout do receptor de IGF-I são afetados mais profundamente, morrendo de falência respiratória após o nascimento (Liu et al., 1993). Estes achados sugerem que a expressão normal de IGF-I e do seu receptor é de extrema importância para o desenvolvimento e crescimento normais.

Em adição a estes resultados, estudos têm mostrado que animais com superexpressão de IGF-I nos osteoblastos apresentam a taxa de formação óssea aumentada com elevação da taxa de mineralização óssea, sem aumentar o número de osteoblastos, sugerindo que o IGF-I age principalmente nos osteoblastos existentes, aumentando sua atividade (Zhao et al., 2000). Além disso, estudos com animais knockouts de IGF-I hepático mostram que o IGF-I exerce um pequeno, porém importante, efeito no crescimento do osso cortical, enquanto não é requerido para a manutenção do osso trabecular de camundongos adultos (Sjogren et al., 
2002). Esses animais apresentam níveis aumentados de GH circulante, que poderia explicar a manutenção do osso trabecular através de seu efeito direto nos osteoblastos.

Além disso, camundongos deficientes de IGF-I apresentam volume de osso trabecular aumentado, com aumento do número de trabéculas e da sua conectividade, e com diminuição do espaço entre as trabéculas (Bikle et al., 2001). Dessa forma, acredita-se que a falta de IGFI resulta em ossos menores, porém mais densos, o que possivelmente ocorre devido à diminuição da reabsorção óssea induzida pelo IGF-I ou ao aumento da responsividade ao GH (Bikle et al., 2001).

Em relação à reabsorção óssea, existem poucos estudos sobre os efeitos do GH e IGF-I nos osteoclastos. Lewinson, Sheng e Hochberg (1993) demonstraram que o GH aumenta o número de osteoclastos na metáfise da tíbia de ratos hipofisectomizados. Sabe-se que GH e IGFBP-5 estimulam a reabsorção por ações diretas e indiretas na diferenciação osteoclástica, e por ativação indireta de osteoclastos maduros, possivelmente via produção local de IGF-I pelos osteoblastos (Kanatani et al., 2000; Nishiyama et al., 1996). Por outro lado, o IGF-I é capaz de estimular a diferenciação e a atividade de osteoclastos em camundongos (Slootweg et al., 1992) e ratos (Hill, Reynolds e Mikle, 1995).

\subsection{O HORMÔNIO TIREOIDEANO}

Os hormônios tireoideanos exercem uma ampla variedade de efeitos no desenvolvimento, crescimento e metabolismo dos tecidos. Os produtos secretórios da glândula tireóide são as iodotironinas, compostos resultantes da ligação de duas moléculas de tirosina iodadas. Nos mamíferos, entre $60-90 \%$ da produção tireoideana corresponde a 3,5,3', $5^{\prime}$-tetraiodotironina (tiroxina ou T4), 10-40\% corresponde a 3,5,3'-triiodotironina (T3) e menos do que $1 \%$ é representado por outras iodotironinas (T3 reverso e T2). A afinidade dos receptores nucleares de hormônios tireoideanos (TRs) é aproximadamente 10 vezes maior pelo T3 em relação ao T4. Por conta disso, considerando os efeitos genômicos do hormônio tireoideano, o T4 funciona como um pró-hormônio, e o T3 como o hormônio ativo. O T4 é convertido a T3, por ação de enzimas celulares, as selenodesiodases das iodotironinas. Essa 
conversão ocorre na própria tireóide e, principalmente, nos tecidos alvo do hormônio tireoideano (Engler e Burger, 1984). Existem três isoformas dessas enzimas, as desiodases do tipo I, II e III (D1, D2 e D3). A D1 converte T4 a T3, T4 a T3 reverso (T3r) e T3 a T2, sendo, portanto, ativadora e inativadora dos hormônios tireoideanos. A D2 converte T4 a T3 e T3r a T2. O T4 é o principal substrato da D2, o que faz dela uma enzima prioritariamente ativadora de T4. A D3 é a principal inativadora dos hormônios tireoideanos, convertendo T4 a T3r, e T3 a T2 (Fig. 1). O hipotireoidismo regula positivamente a atividade da D2 e negativamente a atividade da D3, o oposto sendo observado em casos de tireotoxicose (Bianco et al., 2002).

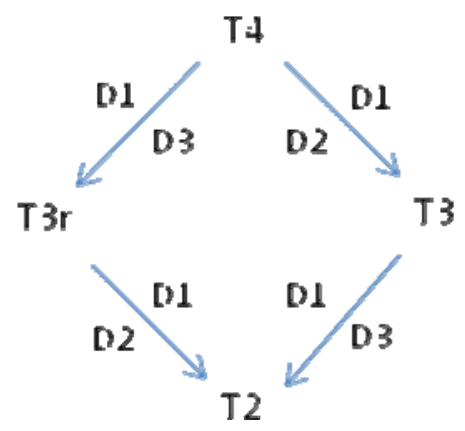

Figura 1: Esquema das ações das selenodesiodases das iodotironinas.

Acredita-se que as ações do hormônio tireoideano são primariamente resultados da sua interação com os TRs. Esses receptores ligam-se a regiões específicas dos genes alvo do hormônio tireoideano, os elementos responsivos dos TRs (TREs) e modificam a sua expressão. É digno de nota, entretanto, que um número de efeitos do hormônio tireoideano ocorre rapidamente e não é afetado por inibidores da transcrição ou tradução, sugerindo que o hormônio tireoideano também promove os seus efeitos via mecanismos não genômicos. Tais ações têm sido descritas em vários tecidos e tipos celulares, incluindo o tecido adiposo marrom, o coração e a hipófise. Os sítios de ações não genômicas têm sido localizados na membrana plasmática, citoplasma e organelas celulares. As ações não genômicas incluem a regulação de canais iônicos, da fosforilação oxidativa e da transcrição de genes mitocondriais e envolve a geração de segundos mensageiros intracelulares e a indução de cascatas sinalizadoras intracelulares (Bassett, Harvey e Williams, 2003; Kavok, Krasilnikova e Babenko, 2001; Watanabe et al., 2005). 


\subsubsection{Receptores Nucleares do Hormônio Tireoideano}

Os receptores nucleares do hormônio tireoideano (TRs) são membros de uma superfamília de fatores de transcrição nucleares hormônio-responsivos (receptores nucleares) que são similares em estrutura e mecanismo de ação (Lazar, 1993). A família de receptores nucleares abrange os receptores dos hormônios esteróides (hormônios do córtex da adrenal, sexuais e a vitamina D3), não-esteróides (retinóides e hormônio tireoideano) e receptores órfãos, cujos ligantes são desconhecidos (Eckey, Moehren e Baniahmad, 2003; Evans, 1988; Lazar, 1993). Esses receptores apresentam duas características estruturais comuns. Uma delas é sua porção que interage com o DNA, denominada de "domínio de ligação ao DNA" (DBD, DNA-binding domain), que apresenta seqüências de aminoácidos formando duas estruturas em forma de alça com uma molécula de zinco cada uma delas, conhecidas como "dedos de zinco" (Freedman, 1992). Os aminoácidos da porção DBD dos receptores determinam uma seqüência específica de DNA no gene, nas quais o receptor se liga, chamada de elemento responsivo ao hormônio tireoideano (TRE, thyroid responsive element) (Freedman, 1992). Permanecendo ligados aos TRE, os TRs podem controlar a expressão gênica independente do ligante. A segunda característica comum aos receptores nucleares é o "domínio de ligação ao ligante" (LBD, ligand-binding domain), que confere especificidade a um determinado ligante (Freedman, 1992).

Existem dois genes que codificam TRs, $\alpha$ e $\beta$. O gene $\alpha$ além de codificar a isoforma funcional TR $\alpha 1$, que se liga ao DNA e ao T3, pode sofrer splicing alternativo resultando em duas outras isoformas, TR $\alpha 2$ e TR $\alpha 3$, que se ligam ao DNA, mas não ao T3, provavelmente, por não apresentar os aminoácidos finais no domínio de ligação do hormônio, existentes na isoforma TR $\alpha 1$ (Lazar, 1993). Devido a essa característica, o TR $\alpha 2$ e o TR $\alpha 3$ funcionam, pelo menos in vitro, como antagonistas da transcrição gênica mediada pelos outros TRs (Katz e Lazar, 1993). O gene TR $\alpha$ pode codificar, também, por splicing alternativo, outras duas isoformas truncadas, o TR $\Delta \alpha 1$ e o TR $\Delta \alpha 2$. Essas isoformas, além de não permitirem a ligação do T3, também não se ligam ao DNA, atuando como antagonistas negativos dominantes (Eckey, Moehren, Baniahmad, 2003; Katz e Lazar 1993). É importante ressaltar que os mecanismos desse antagonismo negativo ainda não foram totalmente elucidados.

O gene TR $\beta$ codifica as isoformas funcionais $\operatorname{TR} \beta 1, \operatorname{TR} \beta 2$ e TR $\beta 3$, que se ligam ao DNA e ao T3. Outra variação de TR $\beta$ resultado de splicing alternativo é a isoforma truncada 
$\mathrm{TR} \Delta \beta 3$, que atua como um antagonista negativo dominante, ligando-se ao T3, mas não ao DNA (Eckey, Moehren, Baniahmad, 2003).

Os TRs são expressos basicamente em todos os tecidos, embora a distribuição desses receptores seja heterogênea. O TR $\alpha 1$ é altamente expresso no músculo esquelético, tecido adiposo marrom (Eckey, Moehren, Baniahmad, 2003), tecido cardíaco (Gloss et al., 2001), cerebelo (Forrest, Sjoberg e Vennstrom, 1990), e tecido ósseo (Abu et al., 1997; Ballock et al., 1999). O TR $\alpha 1$ foi demonstrado em células de osteossarcoma de ratos (Williams, Bland e Sheppard, 1994), em osteoblastos de humanos (Abu et al., 1997) e camundongos (Gruber et al., 1999), em osteoclastos (Allain et al., 1996) e em condrócitos da lâmina epifisial de humanos (Abu et al., 1997) e de ratos (Ballock et al., 1999). O TR 22 é expresso no cérebro, coração, testículos, rins, tecido adiposo marrom e músculo esquelético (Hodin, Lazar e Chin, 1990). Assim como o TR $\alpha 1$, o TR $\alpha 2$ também é encontrado nos osteoblastos, osteoclastos e condrócitos (Abu et al., 1997; Allain et al., 1996; Williams, Bland e Sheppard, 1994). O TR $\beta 1$ é a isoforma mais homogeneamente distribuída, porém, é encontrada em altas concentrações no cérebro, fígado e rins (Hodin, Lazar e Chin, 1990). Os osteoblastos, osteoclastos e condrócitos da lâmina epifisial também expressam o TR $\beta 1$. A isoforma TR $\beta 2$ é expressa quase que exclusivamente na adenohipófise (Hodin, Lazar e Chin, 1990), no hipotálamo, no hipocampo em desenvolvimento e no corpo estriado (Cook et al., 1992). A isoforma TR $\beta 3$, ainda pouco estudada, possui uma distribuição homogênea pelos tecidos (Bassett e Williams, 2003). Considerando a variada distribuição entre as isoformas de TR e suas diferentes ações, é de extrema importância desvendar o papel funcional de cada uma delas.

\subsubsection{O GC-1, um análogo do T3}

Em 1998, Chiellini e colaboradores desenvolveram o GC-1, um análogo do T3 cujas características chave incluem uma ligação com metileno ao invés de uma ligação éter, uma cadeia lateral do ácido oxiacético ao invés de uma cadeia lateral alanina e grupos metil ou isopropil no lugar dos iodetos (Fig. 2) (Chiellini et al., 1998). 

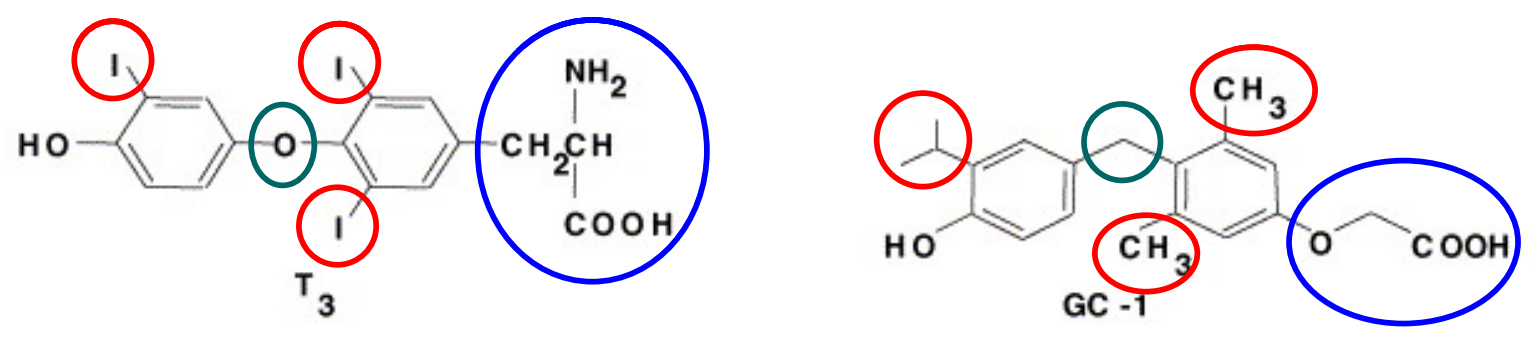

Figura 2: Fórmula Estrutural do T3 e do GC-1. Os círculos coloridos indicam as diferenças estruturais entre os dois compostos (Fonte: Chiellini et al., 1998).

Uma característica muito interessante do GC-1 é que o TR $\beta 1$ apresenta alta afinidade por este análogo. O TR $\beta 1$ liga-se ao GC-1 com a mesma afinidade que se liga ao T3, entretanto, a afinidade do TR $\alpha 1$ pelo GC-1 é 10 vezes menor em comparação à ligação ao T3.

As propriedades de ativação gênica do GC-1 foram testadas em células de mamíferos através da transfecção de plasmídeos repórteres que continham TREs e, também, através da transfecção de plasmídeos que expressavam TR $\alpha 1$ e TR $\beta 1$. Experimentos de transativação celular do tipo dose-resposta demonstram que o GC-1 é um agonista total do TR com potência similar ao T3, entretanto, a sua capacidade de ativação gênica é aproximadamente 10 vezes maior na presença de TR $\beta 1$ do que na presença de TR $\alpha 1$. Assim sendo, o TR $\beta$ exerce seletividade pelo GC-1 nas suas funções de ligação ao receptor e de ativação gênica. Entretanto, essa seletividade não existe em relação ao hormônio tireoideano, já que o TR $\alpha 1$ e TR $\beta 1$ ligam-se ao hormônio com a mesma afinidade.

Os diferentes efeitos do GC-1 no sistema nervoso central (Manzano et al., 2003), tecido adiposo marrom (Ribeiro et al., 2001), hepatócitos e células acinares do pâncreas (Columbano et al., 2006) e na metamorfose dos girinos (Furlow et al., 2004) possivelmente dependem do reconhecimento específico dos genes pelo TR $\beta$. Por outro lado, os efeitos do GC-1 podem também estar relacionados com a distribuição das diferentes isoformas de TR pelo corpo, a qual ocorre de maneira tecido-específica. O GC-1 praticamente não tem efeito na função cardíaca, onde há, predominantemente, a expressão de TR $\alpha 1$, mas diminui os 
níveis séricos de colesterol e triglicérides, o que está de acordo com a alta expressão de TR $\beta 1$ no fígado (Trost et al., 2000).

\subsubsection{O Hormônio Tireoideano e o Tecido Ósseo}

Há mais de 50 anos, vem sendo descrito que o hormônio tireoideano é essencial para o desenvolvimento, maturação e metabolismo ósseos normais (Ray et al., 1954). O excesso de hormônio tireoideano no adulto leva a um aumento da atividade de osteoblastos e de osteoclastos, com predomínio da atividade osteoclástica. Como resultado, o metabolismo ósseo é acelerado favorecendo a reabsorção óssea, balanço negativo do cálcio e perda de massa óssea (Mosekilde e Melsen, 1978). Já no hipotireoidismo, o metabolismo ósseo é reduzido e a massa óssea pode estar ligeiramente aumentada em indivíduos adultos (Vestergaard et al., 2000).

Durante o desenvolvimento, a deficiência do hormônio tireoideano causa atraso generalizado na ossificação intramembranosa e endocondral, somando-se a importantes alterações na lâmina epifisial, tais como redução da sua espessura, desorganização das colunas de condrócitos e prejuízo na diferenciação de condrócitos proliferativos em hipertróficos (Lewinson et al., 1989; Stevens et al., 2000), resultando em redução do crescimento e anormalidades esqueléticas (Allain e McGregor, 1993). Por outro lado, o excesso de hormônio tireoideano resulta em maturação esquelética acelerada com fechamento prematuro da lâmina epifisial, e subsequente diminuição do crescimento ósseo (Allain e McGregor, 1993; O’Shea et al., 2003).

Apesar da reconhecida importância do hormônio tireoideano no desenvolvimento e metabolismo ósseos, seus mecanismos de ação são pouco conhecidos. Entretanto, sabe-se que o hormônio tireoideano atua, no tecido ósseo, de maneira indireta e direta.

\subsubsection{Efeitos do Hormônio Tireoideano no Eixo GH/IGF-I}

Sabe-se que efeitos indiretos do hormônio tireoideano no esqueleto são mediados pelo eixo GH/IGF-I. É bem sabido que a transcrição do gene do GH é regulada pelo T3, através da sua interação com o complexo TR-TRE presente no promotor do gene do GH (Glass et al., 
1987; Koenig et al., 1987). Dessa forma, a condição de hipotireoidismo é acompanhada por uma menor atividade do eixo GH/IGF-I (Nanto-Salonen et al., 1993).

A interação entre as vias de ação do $\mathrm{T} 3$ e $\mathrm{GH}$ na regulação do metabolismo ósseo ocorre em vários níveis, além do efeito do T3 na regulação da transcrição gênica do $\mathrm{GH}$. $\mathrm{O}$ hormônio tireoideano, assim como o GH, é capaz de regular a expressão local de IGF-I. Lewinson, Bialik e Hochberg (1994) mostraram que a expressão protéica de IGF-I na cartilagem condilar está reduzida em ratos hipotireoideos e que o hormônio tireoideano é requerido para sua restauração. Além disso, foi demonstrado que o T3 aumenta a expressão protéica de IGF-I em cultura de osteoblastos de ratos (Lakatos et al., 1993)

O hormônio tireoideano também atua no eixo GH/IGF-I, regulando a expressão dos receptores de GH e IGF-I. Foi mostrado que o tratamento com T3 restaura a expressão de GHR na lâmina epifisial de ratos hipofisectomizados (Gevers et al., 2002) e induz a expressão gênica de IGF-IR em condrócitos da lâmina epifisial de ratos (Ohlsson et al., 1992).

Uma série de estudos tem demonstrado que a concentração sérica de IGFBPs também depende do hormônio tireoideano e do GH. Daughaday et al. (1966) mostraram que a administração de $\mathrm{GH}$ em ratos hipofisectomizados eutireoideanos restaurou os níveis de atividade das IGFBPs. Por outro lado, este aumento não foi observado em animais hipotireoideos tratados com GH (Burstein et al., 1978). Estes dados estão de acordo com Schalch et al. (1978), que demonstraram que o tratamento com T3 é necessário para restaurar os níveis de IGFBPs em ratos hipofisectomizados. Enquanto que o GH foi capaz de aumentar apenas a IGFBP-3, a reposição de T4 normalizou os níveis reduzidos de IGFBP-3 e -4 observados em ratos hipotireoideos adultos sugerindo que a expressão dessa proteína é regulada pelo GH, enquanto que a expressão de IGFBP-4 parece ser independente do eixo GH nesse modelo.

Por outro lado, o eixo GH/IGF-I também pode modular as ações do hormônio tireoideano. Em cultura primária de células da hipófise, o IGF-I inibe a indução pelo T3 da expressão gênica e da secreção do GH (Melmed e Yamashita, 1986), o que pode ocorrer devido ao efeito inibitório do IGF-I sobre o número de TRs. Pellizas et al. (1998) indicaram que, em fígado de ratos normais, o IGF-I modula as ações do hormônio tireoideano por um mecanismo que afeta, pelo menos em parte, a expressão de TRs. Assim sendo, é possível que exista um sistema de feedback negativo, no qual o IGF-I limita as ações estimulatórias do T3 na síntese de IGF-I pela regulação negativa dos TRs. 


\subsubsection{O Papel das Diferentes Isoformas dos Receptores do Hormônio Tireoideano}

Há fortes indícios de que o hormônio tireoideano é capaz de atuar no esqueleto de maneira direta, e independente do eixo GH/IGF-I. A mais forte evidência disso é o fato de que o T3 é capaz de estimular o crescimento ósseo longitudinal em animais hipofisectomizados e, portanto, deficientes de GH (Lewinson et al., 1994).

Outros fatos que evidenciam os efeitos diretos do T3 no esqueleto são a presença de TRs nos osteoblastos, osteoclastos e condrócitos (Williams, Bland e Sheppard, 1994; Abu et al., 1997) e a responsividade dessas células ao T3 quando isoladas em cultura.

Abu et al. (1997) demonstraram uma variação da expressão das isoformas de TR dependendo da localização/atividade de células ósseas humanas. Em superfícies de reabsorção óssea, TR $\alpha 2$ e TR $\beta 1$ foram encontrados em osteoclastos, enquanto TR $\alpha 1$ foi detectado apenas raramente. Em locais de remodelamento ósseo, TR $\alpha 1, T R \alpha 2$ e TR $\beta 1$ foram amplamente expressos em osteoblastos, entretanto, em superfícies de formação óssea, por ossificação intramembranosa, apenas TR $\alpha 2$ e TR $\beta 1$ foram detectados. Em regiões de ossificação endocondral, TR $\alpha 1$ e TR $\beta 1$ foram identificados em condrócitos indiferenciados e TR $\alpha 2$ e TR $\beta 1$, em condrócitos maduros e hipertróficos, enquanto que TR $\alpha 1$ foi raramente identificado nessas células. Segundo Robson et al. (2000), o número de TR $\alpha 1$ ou TR $\alpha 2$ nas colunas de condrócitos decresce com o distanciamento da epífise, assim como a expressão de TR $\beta 1$. Na zona hipertrófica, não foi encontrada expressão de nenhuma isoforma de TR. Estes dados indicam que a expressão do TR diminui com a progressão de diferenciação da lâmina epifisial, sendo os condrócitos hipertróficos não responsivos ao T3.

Apesar da identificação de TRs nos condrócitos da lâmina epifisial e nas células ósseas, a importância funcional das diferentes isoformas de TR é ainda pouco entendida. Williams, Bland e Sheppard (1994) demonstraram que as isoformas TR $\alpha$ l e TR $\beta 1$ estão presentes, funcionalmente e em proporções variadas, em três linhagens de células de osteosarcoma que expressam fenótipos de fibroblasto, pré-osteoblasto, e osteoblasto maduro (ROS 25/1, UMR 106 e ROS17/2.8, respectivamente), o que sugere uma possível mudança na ação do hormônio tireoideano durante o desenvolvimento.

A inativação (knockout) e mutação (knockin) dos receptores de hormônio tireoideano em camundongos têm sido importantes ferramentas para desvendar o papel de cada uma das isoformas de TR nas diversas respostas ao T3. Camundongos $\mathrm{TR} \alpha^{-/}$, que não expressam 
TR $\alpha 1$ e TR $\alpha 2$ e são deficientes de GH e hipotireoideos, apresentam retardo no crescimento, atraso na ossificação endocondral e mineralização, redução da massa óssea, desorganização da lâmina epifisial e redução do número de condrócitos (Fraichard et al., 1997). Num primeiro momento, considerou-se que o retardo no crescimento desses mutantes fosse resultado dos baixos níveis de GH/IGF-I. No entanto, os camundongos com deleção completa do TR $\alpha\left(\mathrm{TR} \alpha^{0 / 0}\right.$; não expressam TR $\alpha 1, \mathrm{~T} \alpha 2$ e as isoformas truncadas) apresentam as mesmas alterações fenotípicas do $\mathrm{TR}^{-/-}$, porém com um estatus endócrino de eutireoidismo e com níveis normais de GH/IGF-I, sugerindo efeitos do hormônio tireoideano no esqueleto independentes do eixo GH/IGF-I (Gauthier et al., 2001).

Mostrou-se, ainda, que animais com inativação do TR $\alpha 1$ (TR $\alpha 1-/-)$ (Wikstrom et al., 1998) ou do TR $\beta$ (TR $\beta-/-)$ (Forrest et al., 1996) não apresentam nenhum efeito fenotípico no esqueleto. Por outro lado, camundongos com a inativação de ambos os receptores $\alpha$ e $\beta$

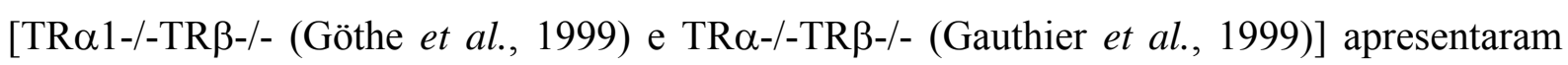
praticamente o mesmo fenótipo de retardo no crescimento e maturação ósseos que ocorre nos

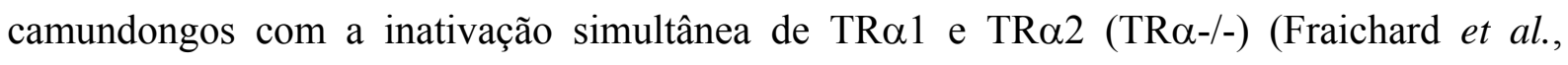
1997), mas com menos severidade. Assim sendo, esses achados sugerem uma substancial redundância funcional entre as isoformas TR $\alpha 1$ e TR $\beta$ no desenvolvimento ósseo.

Além disso, o TR $\alpha 2$ parece ter um papel importante na modulação das ações dos outros receptores, uma vez que os mutantes TR $\alpha-/-$, que não expressam TR $\alpha 1$ e TR $\alpha 2$, mas continuam a expressar as isoformas truncadas TR $\Delta \alpha 1$ e TR $\Delta \alpha 2$, também apresentam defeitos no desenvolvimento ósseo, o que sugere um possível papel do TR $\alpha 2$ nesse processo (Fraichard et al., 1997). Corroborando esses dados, foi demonstrado que o knockout do TR $\alpha 2$ $\left(\mathrm{TR} \alpha 2^{-/}\right)$, que apresenta uma superexpressão do TR $\alpha 1$ e um fenótipo complexo com baixos níveis séricos de T3 e T4 livres e níveis normais de TSH, apresentam mineralização óssea anormal, diminuição do conteúdo mineral ósseo (BMC) do osso cortical da tíbia e diminuição da densidade mineral óssea (BMD) do fêmur, vértebra e do osso trabecular da tíbia (Saltó et al., 2001).

Há, ainda, evidências de que as isoformas truncadas de TR $\alpha(\operatorname{TR} \Delta \alpha 1$ e TR $\Delta \alpha 2)$ tenham um papel negativo no desenvolvimento ósseo, uma vez que camundongos $\mathrm{TR} \alpha^{0 / 0}$ demonstram um fenótipo menos severo de atraso no desenvolvimento ósseo do que 
camundongos $\mathrm{TR} \alpha^{-/-}$, o que sugere um papel fisiológico das isoformas do TR $\alpha$ que não ligam T3 (Gauthier et al., 2001).

É também importante considerar a atividade dos TRs não ligados ao ligante, que normalmente exercem um efeito repressor sobre a transcrição gênica. Essa atividade vem sendo denominada de aporreceptora. Uma evidência da importância dessa atividade foi observada em camundongos $\mathrm{Pax}-\mathrm{-}^{-/}$, que expressam todas as isoformas TR, mas não possuem as células foliculares produtoras de T4 e T3 na glândula tireóide, ou seja, possuem os TRs, mas não os seus ligantes. Esses animais apresentam defeitos ainda mais pronunciados no desenvolvimento ósseo do que camundongos que não expressam nenhum TR (TR $\left.\alpha^{0 / 0} \mathrm{TR}^{-/-}\right)$ (Flamant et al., 2002). Esses achados têm sido interpretados como resultado dos efeitos repressores de TRs não ligados ao ligante. $\mathrm{O}$ interessante é que camundongos mutantes $\mathrm{Pax}-\mathrm{8}^{-}$ ${ }^{/-} \mathrm{TR} \alpha^{0 / 0}$, mas não $\mathrm{Pax}-8^{-/-} \mathrm{TR} \beta^{-/-}$, apresentam reversão parcial do fenótipo ósseo, o que sugere que o TR $\alpha 1$ tenha uma importante atividade aporreceptora durante o desenvolvimento ósseo (Flamant et al., 2002; O'Shea et al., 2002).

\subsubsection{Efeitos Diretos versus Efeitos Indiretos do Hormônio Tireoideano no Esqueleto}

Como já citado, os efeitos adversos do hipotireoidismo no desenvolvimento do esqueleto são acompanhados pela inibição do eixo GH/IGF-I (Nanto-Salonen et al., 1993). Assim sendo, uma questão importante e ainda não solucionada é se os efeitos do T3 no esqueleto são resultados primários das suas ações diretas nas células ósseas ou se são primariamente decorrentes da sua interação com o eixo GH/IGF-I. Alguns estudos sugerem que os efeitos diretos do T3 são provavelmente críticos para o desenvolvimento ósseo. Foi mostrado que o GH, sem o T3, é incapaz de estimular a maturação (Ballock e Reddi, 1994) e organização dos condrócitos da lâmina epifisial (Lewinson et al., 1989) e que a reposição de GH não restaura o defeito na ossificação apresentado por camundongos com knockout do TR $\alpha$ e TR $\beta$ (Kindblom et al., 2001). Além disso, em culturas primárias de condrócitos da lâmina epifisial, o T3 inibe a proliferação celular enquanto que, ao mesmo tempo, induz a diferenciação de condrócitos hipertróficos (Robson et al., 2000).

Nosso grupo de pesquisa vem utilizado o GC-1, como ferramenta farmacológica para elucidar o papel dos TRs no desenvolvimento e metabolismo ósseos. Em um estudo anterior, ratas hipotireoideas foram tratadas com $\mathrm{T} 3$ ou doses equimolares de $\mathrm{GC}-1$ e o 
desenvolvimento esquelético foi analisado. Enquanto o T3 reverteu quase que completamente os defeitos esqueléticos, tais como retardo no crescimento, diminuição da massa óssea e defeito generalizado na ossificação endocondral, decorrentes da defíciência de hormônio tireoideano, o tratamento com GC-1 teve efeitos apenas parciais (Freitas et al., 2005). Diferentemente do T3, o GC-1 não foi capaz de elevar os níveis séricos de IGF-I e de induzir a expressão protéica de IGF-I na lâmina epifisial. Esses achados sugerem que o hormônio tireoideano tem efeitos no desenvolvimento ósseo independentes do eixo GH/IGF-I e mediados pelo TR $\beta$. Assim sendo, a administração de GC-1 em ratos hipotireoideos representa um excelente modelo para investigar efeitos do hormônio tireoideano no desenvolvimento ósseo que são mediados pelo TR $\beta$ e independentes do eixo GH/IGF-I.

Um efeito interessante do GC-1 foi o de induzir parcialmente a ossificação endocondral de ratas hipotireoideas (Freitas et al., 2005). Considerando-se que o efeito do GC-1 na ossificação endocondral foi menos acentuado do que o efeito do T3, é provável que a indução normal desse processo requeira ações do T3 mediadas pelo TR $\alpha 1$ e TR $\beta 1$. De fato, o fenótipo esquelético de camundongos com deleção de TR $\alpha 1, \beta 1$ e $\beta 2$ (TR $\alpha 1-/-T R \beta-/-)$, que apresentam retardo no crescimento e defeito na ossificação das epífises associada com inibição do eixo GH/IGF-I, reforça a visão de que o T3 afeta diretamente a ossificação (Göthe et al., 1999). Nesses animais, mostrou-se que a reposição de GH reverte o fenótipo no crescimento, mas não o defeito na ossificação, o que sugere que os TRs são essenciais para mediar efeitos diretos do T3 na ossificação (Kindlom et al., 2001). Por outro lado, um efeito sinérgico ou aditivo entre o eixo GH/IGF-I e o hormônio tireoideano na ossificação endocondral não pode ser excluído, uma vez que camundongos com inativação dos receptores do GH e IGF-I apresentam atraso na ossificação (Liu et al., 1993; Sjogren et al., 2000). De fato, em camundongos Snell GH-deficientes, o GH tem um efeito claro, embora menos acentuado do que o T4 no tamanho dos centros de ossificação (Smeets e Van Buul-Offers, 1983 ) e; em ratos tireoidectomizados-hipofisectomizados, o T4 aumenta o efeito do GH na ossificação endocondral (Hoskins e Asling, 1977). Assim sendo, novos estudos são necessários para elucidar a participação do TR $\alpha 1$ e GH/IGF-I nesse processo.

De acordo com estudos prévios (Lewinson et al., 1989; Stevens et al., 2000), nós mostramos que a zona proliferativa da lâmina epifisial estava desorganizada e que a diferenciação dos condrócitos hipertróficos estava bloqueada na epífise distal do fêmur das ratas hipotireoideas. Enquanto o T3 reverteu esses defeitos da lâmina epifisial, o GC-1 
induziu alterações morfológicas (aumento do número de condrócitos hipertróficos e da espessura da zona hipertrófica) e moleculares (aumento da expressão do mRNA do Colágeno do tipo X) indicativas da diferenciação dos condrócitos, mas não induziu a organização das colunas de condrócitos proliferativos (Freitas et al., 2005). Vale salientar que o GC-1 não induziu a expressão protéica do IGF-I na lâmina epifisial, o que sugere que os efeitos desse análogo não foram mediados pelo eixo GH/IGF-I. Considerando-se que a organização da zona proliferativa é essencialmente regulada pelo hormônio tireoideano (Lewinson et al., 1989), os nossos achados sugerem que o TR $\alpha 1$ medeia os efeitos do T3 na organização dos condrócitos proliferativos em colunas. Apesar da inabilidade de organizar a zona proliferativa, o GC-1 induziu a expressão do mRNA do colágeno do tipo II nos condrócitos pré-hipertróficos e, de maneira similar ao T3, restabeleceu a espessura da zona proliferativa e aumentou o número de células por coluna de condrócitos proliferativos, o que sugere um efeito positivo na proliferação dos condrócitos in vivo. Efeitos similares do hormônio tireoideano foram observados na lâmina epifisial da tíbia proximal de ratos hipotireoideos (Lewinson et al., 1989). Esse efeito, entretanto, contrasta com a clara ação inibitória do T3 na proliferação de condrócitos in vitro (Ishikawa et al., 1998; Robson et al., 2000) e, provavelmente, é resultado de complexas interações sistêmicas e locais que ocorrem in vivo. Considerando-se que o GH e IGF-I induzem a proliferação de condrócitos in vivo (Ishikawa et al., 1998; Sims et al., 2000) e in vitro (Lindahl et al., 1987), o número reduzido de condrócitos proliferativos em animais hipotireoideos poderia ser explicado pela deficiência de GH/IGF-I que acompanha a deficiência de T3. Entretanto, o efeito positivo do GC-1 sobre o número de condrócitos proliferativos e sobre a espessura da zona proliferativa, sem elevar o IGF-I local e sérico, sugere que o T3 interage com outros fatores para controlar a proliferação dos condrócitos. Entretanto, estudos adicionais, utilizando o GC-1 em associação com o GH podem contribuir para o entendimento do papel de cada hormônio e das isoformas de TR nesse processo.

Outro ponto que merece atenção é o fato de que o GC-1 não promoveu crescimento longitudinal do corpo e tíbia e apenas promoveu um pequeno crescimento no fêmur e vértebra, apesar dos seus efeitos claros na lâmina epifisial (Freitas et al., 2005). Isso é, provavelmente e parcialmente, explicado pela deficiência de IGF-I sérico nos ratos tratados com GC-1. Previamente, foi mostrado que os níveis circulantes de IGF-I parecem ter um papel fundamental no crescimento ósseo linear (Yakar et al., 2002). Entretanto, estudos clássicos mostram que o T4 sozinho estimula o crescimento ósseo longitudinal em ratos hipofisectomizados (Ray et al., 1954; Thorngren e Hanson, 1973), além de ter a conhecida 
função de potenciar o efeito promotor do crescimento mediado pelo eixo GH/IGF-I (Thorngren e Hansson, 1974). Assim sendo, a falta de ou mínimo crescimento observados nos animais tratados com GC-1 podem também ser resultado da falta de ações mediadas pelo TR $\alpha 1$. Estudos adicionais, utilizando GH ou IGF-I em combinação com GC-1, também se fazem importantes para elucidar essa hipótese. De qualquer forma, todos esses achados sugerem que o TR $\alpha 1$ e TR $\beta 1$ são importantes para a arquitetura e funcionalidade da lâmina epifisial e que algumas ações do T3 mediadas pelo TR $\alpha 1$ não podem ser compensadas pelo TR $\beta 1$. Isso é consistente com a expressão de ambas as isoformas na lâmina epifisial de ratos (Robson et al., 2000).

A partir do estudo descrito pudemos concluir que o tratamento crônico de ratas hipotireoideas com GC-1 parcialmente reverte os defeitos no desenvolvimento e maturação do esqueleto resultantes da deficiência de hormônio tireoideano (Freitas et al., 2005). Considerando a seletividade do TR $\beta 1$ pelo GC-1 e a incapacidade desse análogo em elevar os níveis séricos e teciduais de IGF-I, os achados sugerem que o hormônio tireoideano tem efeitos no desenvolvimento ósseo mediados pelo TR $\beta 1$ e independentes do eixo GH/IGF-I. Por outro lado, a incapacidade do GC-1 em reverter totalmente os defeitos no desenvolvimento do esqueleto levanta as seguintes hipóteses: alguns efeitos do T3 no desenvolvimento e maturação do esqueleto (1) são diretos e mediados exclusivamente pelo TR $\alpha 1$; (2) são diretos e mediados exclusivamente pelo TRß1; (3) são diretos e dependem da ação simultânea de ambos os receptores; (4) são indiretos e mediados pela ação direta do eixo GH/IGF-I no esqueleto; ou (5) são diretas e dependem de ações sinérgicas ou complementares do eixo GH/IGF-I. Dessa forma, a principal meta do presente estudo é a caracterização do papel do hormônio tireoideano e da sua interação com o TR $\beta$ e com o eixo GH/IGF-I na regulação do desenvolvimento e crescimento ósseos.

O entendimento do papel das diferentes isoformas de TR no tecido ósseo é relevante não só no sentido de elucidar o papel fisiológico desses receptores, mas, também, no sentido de se aplicar esses achados a condições clínicas. Esse conhecimento contribuirá para o desenvolvimento e posterior utilização clínica de análogos do T3 que permitam que efeitos benéficos do hormônio tireoideano sejam obtidos, tais como supressão de TSH e diminuição da colesterolemia, ao mesmo tempo em que se excluem os seus efeitos deletérios, tais como a perda de massa óssea. Assim sendo, a caracterização da interação do hormônio tireoideano 
com os seus receptores e com o eixo GH/IGF-I no desenvolvimento do esqueleto poderá trazer importantes implicações no manuseio clínico de doenças do desenvolvimento do esqueleto. 


\section{OBJETIVOS}

Investigar se os efeitos do hormônio tireoideano no crescimento e desenvolvimento do esqueleto são resultados primários de ações diretas, mediadas pelo $\operatorname{TR} \alpha, \operatorname{TR} \beta$ ou ambos, ou se são resultado da sua interação com o eixo GH/IGF-I.

\subsection{Objetivos específicos:}

Analisar o efeito da reposição de GH em ratas hipotireoideas tratadas com o GC-1:

- no crescimento longitudinal ósseo;

- na aquisição de massa óssea, avaliada por densitometria óssea;

- na resistência óssea, avaliada por teste biomecânico;

- na organização e diferenciação dos condrócitos da lâmina epifisial, avaliada por histologia e morfometria; e

- no processo de ossificação, avaliada por coloração dos esqueletos com azul de alcian e vermelho de alizarina. 


\section{MATERIAL E MÉTODOS}

\subsection{Animais e Tratamento}

\subsubsection{Experimento I:}

Ratas jovens da linhagem Rattus novergicus (linhagem Wistar) de 21 dias de idade foram obtidas no Biotério Central do Instituto de Ciências Biomédicas da Universidade de São Paulo e mantidos em condições controladas de luz e temperatura (ciclos alternados de claro/escuro de 12 horas em temperatura de aproximadamente $25^{\circ} \mathrm{C}$ ), com acesso ad libitum à ração e água. Os animais foram divididos em 7 grupos (n=8/grupo), nomeados da seguinte forma: (i) Eutiroideo (Eut), (ii) Hipotiroideo (Hipo), (iii) T3, (iv) GC-1, (v) GH, (vi) GH+T3 e (vii) GH+GC-1 (Tabela 1). Em todos os animais, com exceção do grupo controle (Eut), o hipotiroidismo foi induzido através da administração de metimazol 0,1\% (Sigma, St Louis MO, EUA) e perclorato de sódio 1\% (Merck, Darmstadt, Alemanha), adicionados à água de beber, durante todo o período experimental. Após uma semana de tratamento com metimazol e perclorato de sódio, todos os animais, exceto os dos grupos Eut e Hipo, foram tratados com doses diárias de T3, GC-1 e/ou GH por 4 semanas. Os grupos T3 e GC-1 receberam, intraperitonialmente, T3 (Sigma, St Louis MO, EUA) e GC-1 (gentilmente cedido por Thomas Scanlan, Universidade de Oregon, EUA) nas doses de 1,5 $\mu$ g de T3/100g de peso

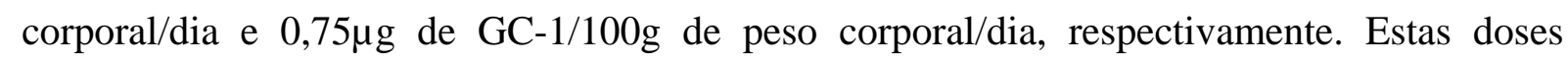
equivalem a 5 doses fisiológicas de T3 e a doses equimolares de GC-1. As doses equimolares de GC-1 foram calculadas de acordo com o peso molecular do T3 (PM = 651) e do GC-1 (PM $=328,4)$. O grupo GH recebeu hormônio do crescimento recombinante humano (Genotropin ${ }^{\circledR}$, Pharmacia AB, Estocolmo, Suécia) na dose de 0,25mg/100g de peso corporal/dia, por injeção subcutânea, dividida em duas doses diárias às $8 \mathrm{~h}$ e 20h. As doses de T3, GC-1 e GH utilizadas no presente estudo já foram utilizadas anteriormente e mostraram promover efeitos no esqueleto (Rosen et al., 1995; Freitas et al., 2005). O grupo GH+T3 recebeu a combinação de GH e T3, e o grupo GH+GC-1 a combinação de GH e GC-1. 
Tabela 1: Tratamento das Ratas

\begin{tabular}{ccc}
\hline Grupo & Bloqueio da Função Tireoideana & Tratamento \\
\hline Eut & - & - \\
Hipo & + & - \\
T3 & + & T3 $(1,5 \mu \mathrm{g} / 100 \mathrm{~g}$ PC/dia $)$ \\
GC-1 & + & GC- $1(0,75 \mu \mathrm{g} / 100 \mathrm{~g}$ de PC/dia $)$ \\
GH & + & GH $(0,25 \mathrm{mg} / 100 \mathrm{~g}$ de PC/dia $)$ \\
GH+T3 & + & GH e T3 \\
GH+GC-1 & + & GH e GC- 1 \\
\hline
\end{tabular}

O bloqueio da função tireoideana foi feito através da administração de metimazol 0,1\% e perclorato de sódio 1\% adicionados à água de beber.

Todos os animais foram pesados a cada dois dias para o acompanhamento da variação do peso corporal ao longo do período experimental e para o ajuste das doses de T3, GC-1 e GH a serem administradas. No início e ao final do tratamento hormonal, foi realizado exame de densitometria óssea para avaliação da massa óssea dos animais. Ao final do tratamento, os animais foram sacrificados por decapitação. O sangue do tronco foi coletado para medida de níveis séricos de T3, T4 e IGF-I por radioimunoensaio. O fêmur direito foi coletado para a análise histológica da lâmina epifisial, e a tíbia esquerda foi armazenada para teste biomecânico.

\subsubsection{Experimento II:}

Para o estudo do efeito dos tratamentos na ossificação, foram utilizados ratos recémnascidos divididos nos seguintes grupos: Eut, Hipo, T3, GC-1, GH, GH+T3 e GH+GC-1 ( $\mathrm{n}=4$ /grupo). Os animais de cada grupo foram tratados da mesma forma do que aqueles do Experimento I, com exceção ao fato de que foram tratados por apenas 1 semana e a administração de T3, GC-1 e/ou GH foi feita através de injeções subcutâneas. Além disso, e considerando-se que os ratos eram neonatos e que, portanto, ainda não bebiam água, a administração de metimazol e perclorato de sódio foi feita via leite materno, uma vez que essas duas drogas são nele liberadas (Glasscock e Nicoll, 1983) e eram administradas à água de beber das mães, a partir do dia do nascimento dos animais até o final do período de 
tratamento na mesma dose do Experimento I. Assim sendo, após uma semana de inibição da função tireoideana, o tratamento de uma semana com T3, GC-1 e/ou GH foi iniciado. Os animais foram pesados a cada dois dias, também, para acompanhamento da variação do peso corporal e para o ajuste das doses a serem administradas. Após uma semana de tratamento hormonal, os animais foram sacrificados por $\mathrm{CO}_{2}$. Imediatamente após o sacrifício, o comprimento corporal longitudinal dos animais foi medido da ponta do focinho até a ponta da cauda, com auxílio de um paquímetro eletrônico digital (Vonder, São Paulo, Brasil). Os animais foram dissecados e os esqueletos foram corados com vermelho de alizarina e azul de alcian para análise do processo de ossificação.

\subsection{Parâmetros Séricos}

Logo após o sacrifício, o sangue do tronco dos animais foi coletado, separado por centrifugação e congelado para posterior análise por radioimunoensaio (RIE). Os níveis séricos de T4 e T3 totais foram medidos por kits comerciais (RIA-gnost T4 and RIA-gnost T3, CISbio International, France). Para os ensaios de T3 e T4, curvas padrão foram construídas em nosso laboratório com um "pool” de soro de rato adsorvido por carvão ativo. A concentração sérica de IGF-I foi medida utilizando-se kit designado para ratos (Diagnostic System Laboratories, Webster, EUA). Para todos estes testes, foi utilizado o Contador Gama do Laboratório Multiusuário do Departamento de Anatomia do ICB-USP (1470 Wizard Automatic Gama Counter, PerkinElmer, EUA).

\subsection{Medida da Massa Óssea por Densitometria Óssea}

A medida da massa óssea foi realizada de forma não invasiva através da densidade mineral óssea (BMD - bone mineral density). O BMD foi medido por Dual Energy X-Ray Absorptiometry (DEXA) em equipamento Norland (Norland Medical Systems, White Plains, NY, USA). As grandezas medidas pelo DEXA são a área óssea, expressa em $\mathrm{cm}^{2}$, e o conteúdo mineral ósseo (BMC - bone mineral content), expresso em gramas. A partir desses parâmetros, calcula-se o BMD, expresso em $\mathrm{mg} / \mathrm{cm}^{2}$.

Foram realizados dois exames de densitometria óssea: um no dia do início do tratamento hormonal e outro após as quatro semanas deste tratamento. Para a realização 
desses exames, os animais foram anestesiados com uma mistura de xilasina (Rompum ${ }^{\circledR}$, Bayer SA, São Paulo, Brasil) e quetamina (Ketamina ${ }^{\circledR}$, Sespo, São Paulo, Brasil), nas doses de 10 e $30 \mathrm{mg} / \mathrm{kg}$ de peso corporal, respectivamente, administradas intra-peritonealmente. As ratas foram colocadas no densitômetro na posição prona com os membros posteriores abduzidos e os quadris, joelhos e tornozelos flexionados a 90 graus. Para limitar ao máximo a área de exame, o que permite o ajuste do equipamento em um modo de maior resolução, foi realizado o exame do corpo posterior, que inclui a coluna lombar de L2 a L6, o cíngulo pélvico, os membros posteriores e as quatro primeiras vértebras caudais (Ca1-Ca4). O equipamento foi ajustado no modo de resolução de $0,5 \mathrm{~mm} \times 0,5 \mathrm{~mm}$, com velocidade de 3 $\mathrm{mm} / \mathrm{s}$, para o primeiro exame, e $5 \mathrm{~mm} / \mathrm{s}$, para o segundo exame.

Para a análise dos resultados, as regiões de interesse foram selecionadas manualmente através de software específico, delimitando-se o perímetro dessas regiões a partir do exame do corpo posterior. As regiões de interesse foram vértebras lombares (L2-L5), ambos os fêmures e as tíbias e o corpo posterior. Para a análise dos exames, o histograma (BMD Histogram Averaging Width) foi ajustado para $0,0125 \mathrm{~g} / \mathrm{cm}^{2}$. Este parâmetro refina a distribuição dos dados do exame, permitindo a definição do limiar entre osso e tecidos moles (massa magra e massa gorda). Para garantir que o histograma escolhido permitisse uma boa separação entre osso e tecido mole, uma região teste, de $0,5 \mathrm{~cm}$ x $0,5 \mathrm{~cm}$, foi posicionada sobre uma porção específica do corpo de cada animal que incluía apenas tecido mole. Os valores de BMD da região teste deveriam ser sempre iguais a 0 (zero).

A precisão do equipamento in vivo das diferentes regiões de interesse foi avaliada calculando-se o coeficiente de variação $[\mathrm{CV}=(100 \mathrm{x}$ desvio padrão $) /$ média $]$ de 6 exames repetidos de uma rata Wistar de um mês de idade. O animal foi reposicionado após cada exame. O CV da BMD do corpo total, coluna lombar, fêmur e tíbia foram de 0,7\%, 1,8\%, $0,3 \%$ e $0,2 \%$, respectivamente. A precisão in vitro foi também expressa como CV e calculada medindo-se o BMD de um phantom, com uma densidade nominal de 0,929 g/ $\mathrm{cm}^{2}$. Este CV foi de $0,8 \%$ ao longo de estudo. A performance do sistema foi acessada e mantida através do quality assurance test (QA test), que inclui a calibração do densitômetro e o exame do phanton. O QA test foi realizado todos os dias em que os exames foram realizados.

Considerando-se a possibilidade de assimetria funcional entre os membros e conseqüente predominância de massa óssea entre um membro e o outro (Fox et al., 1995), o 
BMD do fêmur e tíbia de cada animal foi expresso como média entre os membros esquerdo e direito.

Com o objetivo de avaliar o efeito do T3, GC-1 e GH em regiões com predomínio de osso cortical ou trabecular, foram analisadas as regiões proximal e distal (com predomínio de osso trabecular) e média (com predomínio de osso cortical) do fêmur e tíbia. Cada uma dessas regiões correspondia a um terço do comprimento total do respectivo osso.

Para minimizar as diferenças basais individuais dos animais, foi calculada a variação de BMD (ganho ou perda) de cada região ( $\triangle \mathrm{BMD}$ = BMD final - BMD inicial).

\subsection{Crescimento Corporal Longitudinal}

Nos dias dos exames de densitometria óssea, quando os animais estavam anestesiados, foi medido o comprimento corporal longitudinal, da ponta do focinho até a base da cauda. O crescimento longitudinal foi calculado pela diferença entre medida final e basal (crescimento longitudinal = comprimento II - comprimento I).

\subsection{Parâmetros Biomecânicos Ósseos}

Os testes biomecânicos permitem medidas diretas da capacidade de um determinado segmento ósseo de resistir ao estresse mecânico. Essas medidas detêm um grande valor na análise do efeito de qualquer fator que afete a massa óssea, uma vez que a análise da massa óssea tem, na maioria das vezes, a finalidade de determinar habilidade de um determinado segmento ósseo de resistir ao estresse mecânico ou de, conseqüentemente, sofrer fraturas. Considerando-se que a massa óssea está diretamente relacionada à resistência óssea, mas que uma maior ou menor massa óssea não necessariamente reflete uma maior ou menor resistência óssea, os testes biomecânicos permitem uma avaliação mais precisa do impacto de determinados fatores sobre o esqueleto.

Assim sendo, a tíbia esquerda de cada animal foi dissecada e mantida em salina a $-20^{\circ}$ C até o momento das análises. Os parâmetros biomecânicos foram obtidos pelo Ensaio de Flexão de Três Pontos, no laboratório da Profa. Dra. Keico Nonaka, no Departamento de Ciências Fisiológicas, da Universidade Federal de São Carlos. Esse ensaio foi realizado em 
um sistema para teste de materiais Instron, modelo 4444 (Instron Corporation, MA, USA), utilizando-se uma célula de carga com capacidade máxima de 100 kgf. Durante o ensaio, as extremidades das tíbias foram apoiadas em dois roletes, posicionados sobre um suporte, sendo que a distância entre os apoios de 21,7 mm. Uma força foi aplicada perpendicularmente ao eixo longitudinal do osso no ponto médio entre os dois apoios, no sentido póstero-anterior da tíbia, por uma haste cilíndrica com rolete de 3,0 mm fixado em sua extremidade (Fig. 3), a uma velocidade constante de $5 \mathrm{~mm} / \mathrm{min}$ até o momento da ruptura do osso.

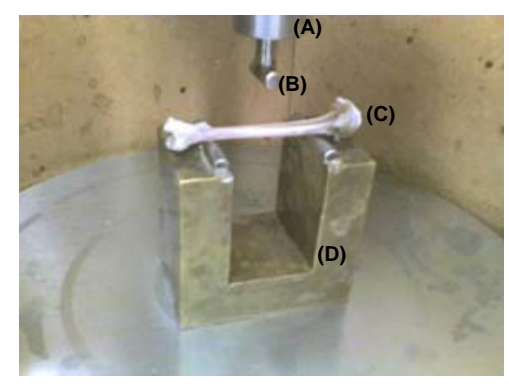

Figura 3: Esquema do teste de flexão de três pontos: (A) haste; (B) rolete; (C) osso e (D) suporte.

A força aplicada e o deslocamento da haste cilíndrica foram monitorados e registrados através de um software próprio do equipamento. A partir desse ensaio, uma curva forçadeformação foi obtida (Fig. 4). A deformação, medida em milímetros (mm), corresponde à distância percorrida pela haste cilíndrica de carga registrada pelo equipamento no ponto inicial até a ruptura do osso e, portanto, corresponde a deformação sofrida pelo osso. Nesta curva (Fig. 4), observa-se uma porção inicial onde há uma relação linear entre a força aplicada ao osso e a deformação por ele sofrida. Essa porção representa a região elástica da curva e é obtida por regressão linear. Na região elástica, a deformação observada no osso é reversível após a retirada da força. A porção não linear da curva, chamada de região plástica, reflete deformações permanentes sofridas pelo osso. A porção elástica e plástica da curva forçadeformação são divididas por uma fronteira imaginária, chamada de “yield point”, que corresponde ao limite elástico. 


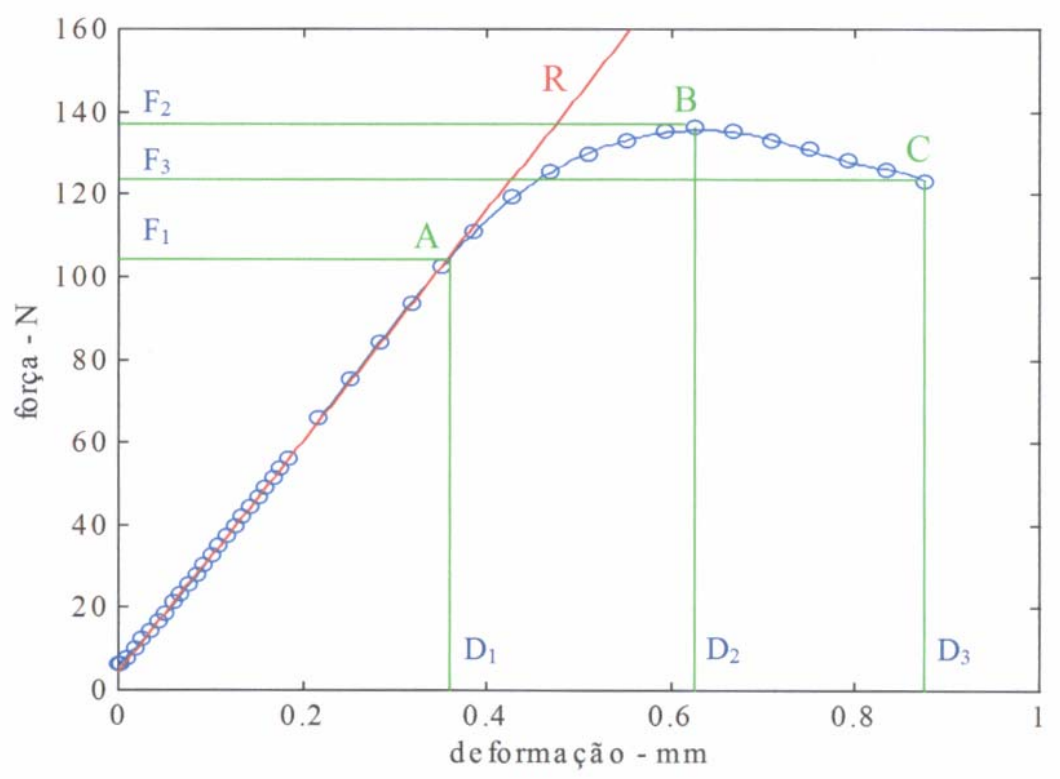

Figura 4: Curva Força-Deformação. A - limite elástico ("yield point"); B - ponto máximo; C - ponto de quebra do osso; R - reta ajustada à fase elástica; F1 - força no limite elástico; F2 - força máxima; F3 - força de ruptura; D1 - deformação no limite elástico; D2 - deformação no ponto de força máxima; D3 - deformação no ponto de ruptura.

Através da curva força-deformação, foram analisados os seguintes parâmetros:

- Carga Máxima (N): corresponde à maior força aplicada durante o ensaio, referindo-se força máxima à qual o osso é capaz de resistir.

- Rigidez Óssea (N/mm): também chamado de Módulo Elástico, é determinada pela inclinação da reta da fase elástica da curva força-deformação. Quanto mais inclinada é esta reta, mais rígido é o osso.

- Resiliência (mJ): propriedade do osso de retornar à sua forma original após uma deformação elástica, e corresponde à energia absorvida por um material durante a deformação elástica. Esse parâmetro equivale a toda área abaixo da região elástica da curva força-deformação.

- Tenacidade (MPa): capacidade do osso de resistir a uma fratura, e corresponde à quantidade de energia necessária para causar a fratura no osso. Esse parâmetro equivale à área total abaixo da curva força-deformação (região elástica + região plástica). 


\subsection{Histologia e Morfometria da Lâmina Epifisial}

O fêmur direito de cada animal foi fixado em uma solução de paraformaldeido 4\% a temperatura ambiente por 1 semana. Posteriormente, as amostras foram lavadas com água corrente e descalcificadas em solução de EDTA 4,2\%, pH 7, a temperatura ambiente e sob agitação. Após a descalcificação, as amostras foram processadas como se segue. Os ossos foram lavados com água para a retirada do excesso de EDTA. Em seguida, sofreram processo de desidratação sendo submetidos a uma bateria de álcoois ascendentes (álcool 70\%, 2 vezes por 30 minutos; álcool 95\%, 2 vezes por 30 minutos e álcool 100\%, 3 vezes por 1 hora). As amostras foram, então, diafanizadas em xilol (3 vezes por 20 minutos) e embebidas em Paraplast (Merck, Darmstadt, Alemanha) a $60{ }^{\circ} \mathrm{C}$ (3 vezes por 50 minutos). Cortes longitudinais de espessura de $5 \mu \mathrm{m}$ foram preparados e corados com hematoxilina e eosina. Foram realizadas medidas morfométricas da lâmina epifisial com auxílio do programa ImagePro Plus (Media Cybernetics, Silver Spring, MD, EUA). Os parâmetros medidos foram: espessura da lâmina epifisial e das suas zonas (reserva, proliferativa e hipertrófica), e número de condrócitos proliferativos por coluna.

\subsection{Análise do Processo de Ossificação - Preparação dos Esqueletos}

Após o sacrifício dos animais de 2 semanas de idade, os esqueletos foram cuidadosamente dissecados pela retirada da pele, músculos e vísceras. Os esqueletos foram fixados em metacam (60\% de metanol, 30\% de clorofórmio e 10\% acido acético), overnight, e transferidos para etanol 100\%, também overnight. As amostras foram coradas com solução de azul de alcian (150 mg azul de azul de alcian em $80 \mathrm{~mL}$ etanol e $20 \mathrm{~mL}$ ácido acético) por 48 horas. Após este período, os esqueletos foram colocados em etanol 95\% por algumas horas, para retirada do excesso do corante, e depois em hidróxido de potássio 1\% por mais 24 horas. Os esqueletos foram corados com solução de vermelho de alizarina (50 mg/L vermelho de alizarina em hidróxido de potássio 2\%) por algumas horas. As amostras foram, então, colocadas em hidróxido de potássio 1\%/glicerol 20\% por 48 horas. Os esqueletos corados foram armazenados e fotografados em solução etanol-glicerol v/v. Foram realizadas medidas morfométricas da área do fontículo posterior da calota craniana e do centro secundário de ossificação do fêmur dos animais com auxílio do programa Image-pro Plus (Media Cybernetics, Silver Spring, MD, EUA). 


\subsection{Análise dos Resultados}

O teste T-pareado foi empregado para avaliar a variação (ganho ou perda) de determinados parâmetros estudados (medida basal vs. medida final). A significância estatística da diferença entre os valores médios dos grupos para qualquer parâmetro foi testada pela análise de variância (ANOVA) ou pelo teste-t (Student t-test). ANOVA foi sempre seguida pelo teste de comparação múltipla Student-Newman-Keuls, para detectar quais grupos são significativamente diferentes entre si. Os resultados foram expressos como média \pm erro padrão da média (EPM). Para a realização dos testes estatísticos foi utilizado o software Instat Instant Biostatistics; para a construção de gráficos foi utilizado o software Prism (ambos proveniente da GraphPad Software, São Diego, CA, EUA). 


\section{RESULTADOS}

\subsection{Experimento I}

\subsubsection{Níveis séricos de T4, T3 e IGF-I}

Todos os grupos tratados apresentaram níveis séricos de T4 diminuídos entre 14 e 19 vezes em comparação aos animais eutireoideos $(\mathrm{p}<0,001)$, indicando a eficiência da indução do hipotireoidismo pelo tratamento com metimazol e perclorato de sódio (Fig. 5A e 5B). Os níveis séricos de T3 dos animais dos grupos T3 e GH+T3 foram 5,2 vezes e 4,4 vezes maiores do que os valores apresentados pelo grupo Eut $(\mathrm{p}<0,001)$, respectivamente. Por outro lado, os grupos Hipo e GC-1 apresentaram diminuição significativa dos níveis séricos de T3 de 5,4 e 9,1 vezes, respectivamente ( $\mathrm{p}<0,001$ versus Eut). Um resultado interessante desse estudo foi que o tratamento com GH, sozinho ou em combinação com GC-1, aumentou, estatisticamente, os níveis séricos de T3 em comparação ao grupo Hipo (aproximadamente 1,8 vezes, $\mathrm{p}<0,05$ ) (Fig. $5 \mathrm{C}$ e $5 \mathrm{D}$ ).

Como mostrado na Fig. 5E e 5F, os níveis séricos de IGF-1 dos grupos Hipo e GC-1 foram 6,5 e 4,1 vezes, respectivamente, menores do que os do grupo Eut $(p<0,001)$. Em contrapartida, os tratamentos com T3 e GH aumentaram os níveis séricos de IGF-I. Os grupos T3, GH, GH+T3 e GH+GC-1 apresentaram aumento entre 5,2 e 6,9 vezes em comparação ao grupo Hipo $(\mathrm{p}<0,001)$. Além disso, o aumento dos níveis de IGF-I mostrado pelo grupo $\mathrm{GH}+\mathrm{T} 3$ foi estatisticamente maior do que os dos grupos T3 $(\mathrm{p}<0,01)$ e $\mathrm{GH}(\mathrm{p}<0,001)$. 
A
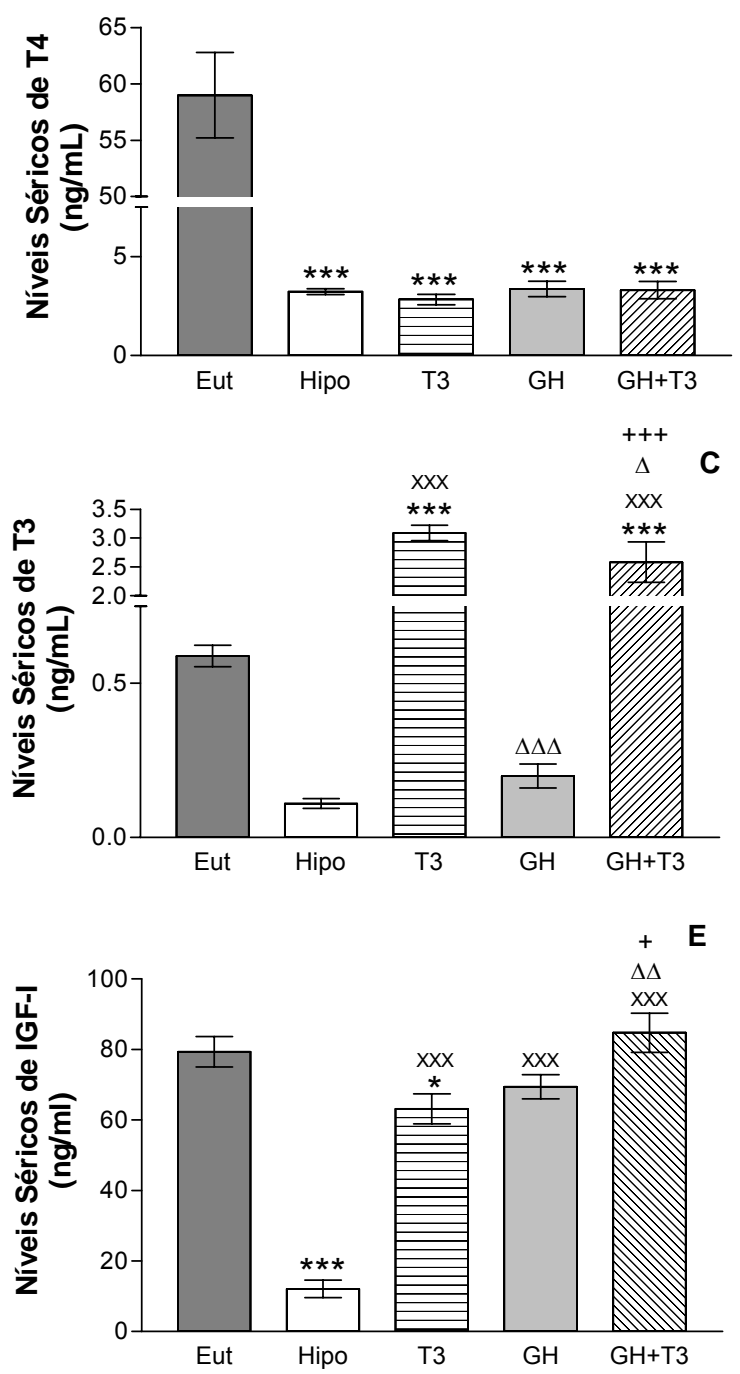

B

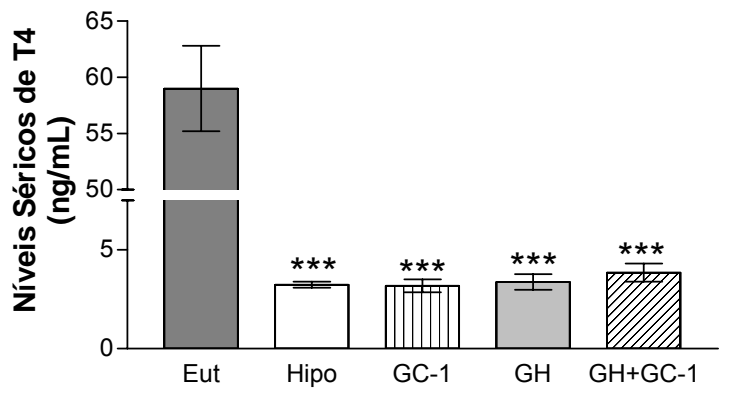

D

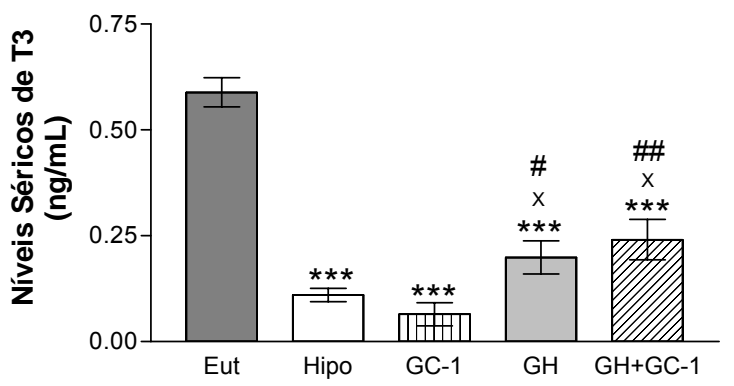

$\mathbf{F}$

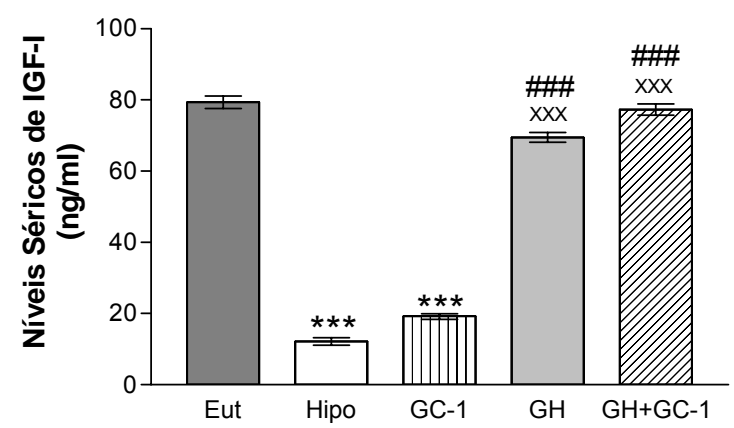

Figura 5: Efeito do tratamento com T3, GC-1 e/ou GH nos níveis séricos de T4 (A e B), T3 (C e D) e IGF-I (E e F) de ratas jovens hipotireoideas. Os animais receberam diariamente injeções de GH sozinho ou em combinação com T3 (A, C e E) ou com GC-1 (B, D e F). Todos os valores são expressos em média \pm EPM ( $n=6-8$ por grupo). $P<0,001$ (ANOVA). * $p<0,05$ e *** $p<0,001$ versus Eut; $x p<0,05$ e xxx $p<0,001$ versus Hipo; $\Delta p<0,05, \Delta \Delta p<0,01$ e $\Delta \Delta \Delta$ $p<0,001$ versus T3; \# $p<0,05$, \#\# $p<0,01$ e \#\# $p<0,001$ versus $G C-1 ;+p<0,05$ e +++ $p<0,001$ versus $G H$, por Student-Newman-Keuls.

\subsubsection{Peso corporal}

O ganho de peso corporal (peso final - peso basal) durante todo o período de tratamento (Tabela 2 e 6) foi estatisticamente significante em todos os grupos ( $p<0,001$, por teste T-pareado).

Tabela 2: Efeito do tratamento com T3 e/ou GH no Peso Corporal. 


\begin{tabular}{|c|c|c|c|}
\hline & Peso Basal & Peso Final & Variação de Peso \\
\hline Eut & $47,5 \pm 2,0$ & $163,4 \pm 6,2^{a}$ & $115,9 \pm 7,8$ \\
\hline Hipo & $46,8 \pm 1,5$ & $59,4 \pm 2,1^{\mathrm{a}}$ & $12,5 \pm 1,1^{\mathrm{c}}$ \\
\hline T3 & $47,1 \pm 1,1$ & $121,0 \pm 2,7^{\mathrm{a}}$ & $73,87 \pm 3,0^{c d}$ \\
\hline $\mathrm{GH}$ & $50,1 \pm 1,6$ & $98,4 \pm 4,5^{\mathrm{a}}$ & $52,3 \pm 5,4^{\mathrm{cd} \mathrm{e}}$ \\
\hline $\mathrm{GH}+\mathrm{T} 3$ & $48,0 \pm 1,4$ & $179,2 \pm 3,8^{a}$ & $131,2 \pm 3,9^{\mathrm{bdfg}}$ \\
\hline
\end{tabular}

Os valores estão apresentados como média \pm EPM ( $n=6-8$ para todos os grupos). A significância da variação do peso corporal (medida final - inicial) foi avaliada por teste T-pareado. a $\mathrm{p}<0,001$ versus peso basal, $b \mathrm{p}<0,05$ versus Eut, $c \mathrm{p}<0,001$ versus Eut, $d$ $p<0,001$ versus Hipo, e $p<0,01$ versus T3, $f p<0,001$ versus T3, $g p<0,001$ versus $\mathrm{GH}+\mathrm{T} 3$.

Tabela 3: Efeito do tratamento com GC-1 e/ou GH no peso corporal.

\begin{tabular}{|c|c|c|c|}
\hline & Peso Basal & Peso Final & Variação de Peso \\
\hline Eut & $47,5 \pm 2,0$ & $163,4 \pm 6,2^{\mathrm{a}}$ & $115,9 \pm 7,8$ \\
\hline Hipo & $46,8 \pm 1,5$ & $59,4 \pm 2,1^{\mathrm{a}}$ & $12,5 \pm 1,1^{b}$ \\
\hline GC-1 & $46,6 \pm 1,9$ & $81,2 \pm 2,3^{a}$ & $34,6 \pm 2,9$ bc \\
\hline $\mathrm{GH}$ & $50,1 \pm 1,6$ & $98,4 \pm 4,5^{\mathrm{a}}$ & $52,3 \pm 5,4^{b d e}$ \\
\hline $\mathrm{GH}+\mathrm{GC}-1$ & $49,6 \pm 2,0$ & $113,3 \pm 4,6^{a}$ & $63,8 \pm 3,3^{b d f}$ \\
\hline
\end{tabular}

Os valores estão apresentados como média \pm EPM ( $n=6-8$ para todos os grupos). A significância da variação do peso corporal (medida final - inicial) foi avaliada por teste T-pareado. a $\mathrm{p}<0,001$ versus peso basal, $b \mathrm{p}<0,001$ versus Eut, $c p<0,01$ versus Hipo, $d p<0,001$ versus Hipo, e $p<0,05$ versus $G C-1, f p<0,001$ versus $G C-1$.

Na primeira semana de indução do hipotireoidismo, não foi observada diferença significativa entre o peso corporal dos animais (Fig. 6A e 6B). No início do tratamento hormonal (dia 8 do período experimental), somente o grupo Eut mostrou peso corporal estatisticamente maior do que o de todos os outros grupos, enquanto que, a partir do oitavo 
dia de tratamento hormonal (dia 15 do período experimental), todos os grupos tratados apresentaram peso corporal estatisticamente maior do que o grupo Hipo (Fig. 6A e 6B). Além disso, neste mesmo período, os grupos T3 e GH apresentaram valores de peso corporal semelhantes (Fig. 6A), assim como os grupos GC-1, GH e GH+GC-1 (Fig. 6B). A partir do décimo sétimo dia de tratamento hormonal (dia 24 do período experimental), o grupo GH+T3 apresentou peso corporal semelhante ao grupo Eut, e o grupo tratado com T3 apresentou peso corporal maior do que o grupo tratado com GH (Fig. 6A). Ao final do tratamento, o grupo $\mathrm{GH}+\mathrm{T} 3$ apresentou peso corporal maior do que todos os outros grupos (Fig. 6A). Os tratamentos com GH ou GC-1 promoveram efeitos similares sobre o peso corporal durante quase todo o período de tratamento, entretanto, a partir do vigésimo quarto dia de tratamento (dia 31 do período experimental), o grupo GH apresentou peso estatisticamente maior do que o grupo GC-1 (Fig. 6B). Por outro lado, a partir do décimo terceiro dia de tratamento hormonal (dia 20), o grupo GH+GC-1 apresentou peso corporal significativamente maior do que o grupo GC-1 e eventualmente maior do que o grupo GH (Fig. 6B). 

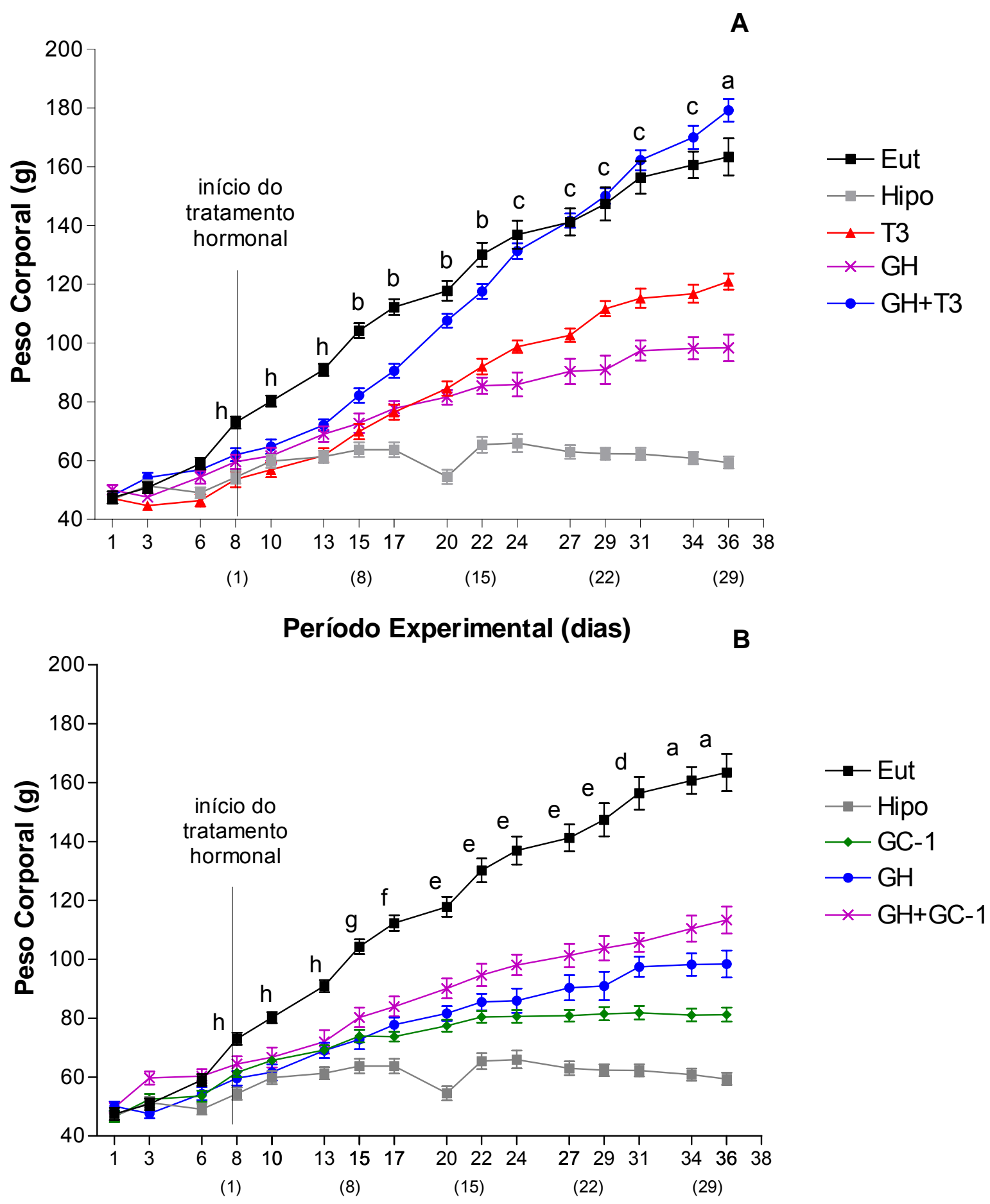

\section{Período Experimental (dias)}

Figura 4: Efeito do tratamento com T3, GC-1 e/ou GH na variação do peso corporal de ratas jovens hipotireoideas. Os animais receberam diariamente injeções de $\mathrm{GH}$ sozinho ou em combinação com T3 (A) ou com GC-1 (B). O número entre parênteses corresponde aos dias de tratamento hormonal. Todos os valores são expressos em média \pm EPM ( $n=6-8$ por grupo). $\mathrm{P}<0,05$ (ANOVA). (a) todos os grupos são diferentes; (b) todos os grupos são diferentes, mas $\mathrm{T} 3=\mathrm{GH}$, (c) todos os grupos são diferentes, mas Eut $=\mathrm{GH}+\mathrm{T} 3$, (d) todos os grupos são diferentes, mas $\mathrm{GH}=\mathrm{GH}+\mathrm{GC}-1$, (e) todos os grupos são diferentes, mas $\mathrm{GH}$ = GC-1, (f) todos os grupos são diferentes, mas $\mathrm{GH}=\mathrm{GC}-1$ e $\mathrm{GH}+\mathrm{GC}-1$, (g) todos versus Eut e Hipo, (h) todos versus Eut (h) por Student-Newman-Keuls. 


\subsubsection{Crescimento Corporal Longitudinal}

A Fig. 7 mostra o efeito do tratamento com T3, GC-1 e/ou GH no crescimento corporal longitudinal (comprimento final - comprimento inicial). Todos os grupos, com exceção do Hipo, apresentaram aumento significativo no crescimento longitudinal $(\mathrm{p}<0,05$ por teste T-pareado). Os animais do grupo Eut apresentaram um aumento do comprimento de aproximadamente $40 \%$ em relação aos seus valores basais, sendo estatisticamente maior do que todos os outros grupos ( $\mathrm{p}<0,01$ versus $\mathrm{T} 3, \mathrm{p}<0,001$ versus outros grupos), exceto o GH+T3 (Fig. 7A). O grupo Hipo não apresentou crescimento corporal, sendo diferente estatisticamente de todos os grupos ( $\mathrm{p}<0,01$ versus GC-1, $\mathrm{p}<0,001$ versus demais grupos). Os grupos T3 e GH+T3 mostraram ganho de comprimento corporal de 16 e 20 vezes maior do que o Hipo $(\mathrm{p}<0,001)$, respectivamente. Estes grupos também apresentaram crescimento corporal significativamente maior do que o grupo GH (3,5 e 4,2 vezes, respectivamente, $\mathrm{p}<0,001)$. Nota-se, ainda, que o tratamento com $\mathrm{GH}+\mathrm{T} 3$ foi o único a restabelecer totalmente o crescimento corporal longitudinal, promovendo ganho de comprimento corporal significativamente maior do que o T3 ou GH. Os animais tratados com GC-1 ou GH tiveram um crescimento de aproximadamente 2,4 vezes $(\mathrm{p}<0,01)$ e 4,6 vezes $(\mathrm{p}<0,001)$, respectivamente, maior do que o grupo Hipo, enquanto que o grupo GH+GC-1 apresentou crescimento de 6,7 vezes maior em relação aos animais hipotireoideos $(\mathrm{p}<0,001)$ (Fig. 7B). Os animais dos grupos GH e GH+GC-1 apresentaram crescimento de 2,0 vezes $(\mathrm{p}<0,05)$ e 2,9 vezes $(\mathrm{p}<0,001)$ maior do que os grupos GC-1.

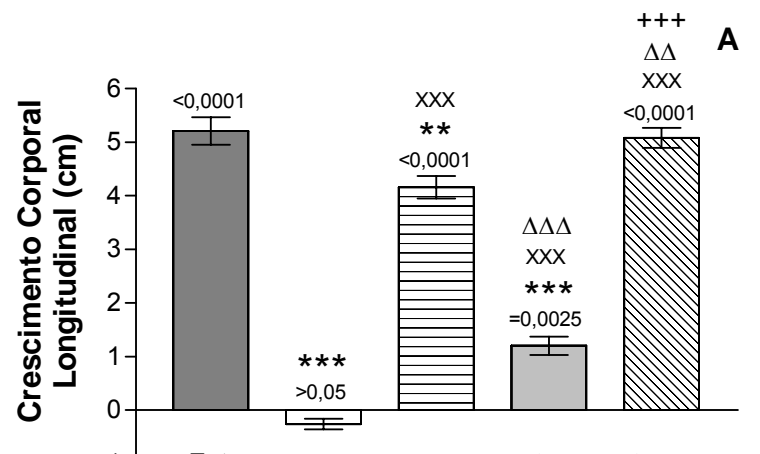

B

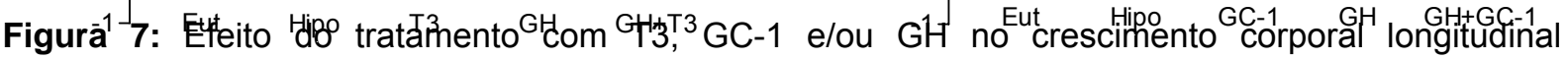
(comprimento final - comprimento inicial) de ratas jovens hipotireoideas. Os animais receberam diariamente injeções de $\mathrm{GH}$ sozinho ou em combinação com T3 (A) ou com GC-1 (B). Todos os valores são expressos em média \pm EPM ( $n=6-8$ por grupo). $P<0,001$ (ANOVA). ${ }^{* *} p<0,01$ e ${ }^{* * *} p<0,001$ versus Eut; $x x p<0,01$ e xxx $p<0,001$ versus Hipo; $\Delta \Delta$ $p<0,01$ e $\Delta \Delta \Delta p<0,001$ versus T3; \# $p<0,05$ e \#\#\# $p<0,001$ versus GC- 1 ; +++ $p<0,001$ versus GH por Student-Newman-Keuls. Os valores sobre as barras indicam a significância estatística da variação do comprimento corporal ao longo do estudo dentro do próprio grupo por teste t-pareado.

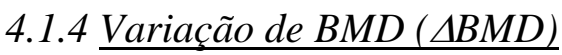


A Fig. 8 mostra a variação de BMD ( $\triangle \mathrm{BMD}=\mathrm{BMD}$ final $-\mathrm{BMD}$ basal $)$ do corpo posterior. Todos os grupos apresentaram ganho significativo de $\operatorname{BMD}(\mathrm{p}<0,05$ por teste $\mathrm{T}$ pareado). O grupo Eut apresentou um aumento de BMD de 2,4 vezes em relação aos seus valores basais, sendo que seu $\triangle \mathrm{BMD}$ foi estatisticamente diferentes de todos os outros grupos $(\mathrm{p}<0,001)$. O $\triangle \mathrm{BMD}$ apresentado pelos grupos T3 e GH+T3 foi aproximadamente 2,4 vezes maior do que o $\triangle B M D$ do grupo Hipo $(\mathrm{p}<0,001)$ (Fig. 8A). O ganho de BMD no corpo posterior desses dois grupos também foi maior do que aquele apresentado pelo grupo GH $(\mathrm{p}<0,001)$. Os grupos GC-1 e GH apresentaram $\triangle \mathrm{BMD}$ 1,3 vezes maiores do que o grupo Hipo. Contudo, estes valores de $\triangle \mathrm{BMD}$ não diferem estatisticamente do apresentado pelo grupo Hipo. O grupo GH+GC-1 apresentou $\triangle \mathrm{BMD}$, aproximadamente, 1,5 vezes maior do que o grupo Hipo $(\mathrm{p}<0,05)$ (Fig. $8 \mathrm{~B})$.

A

B
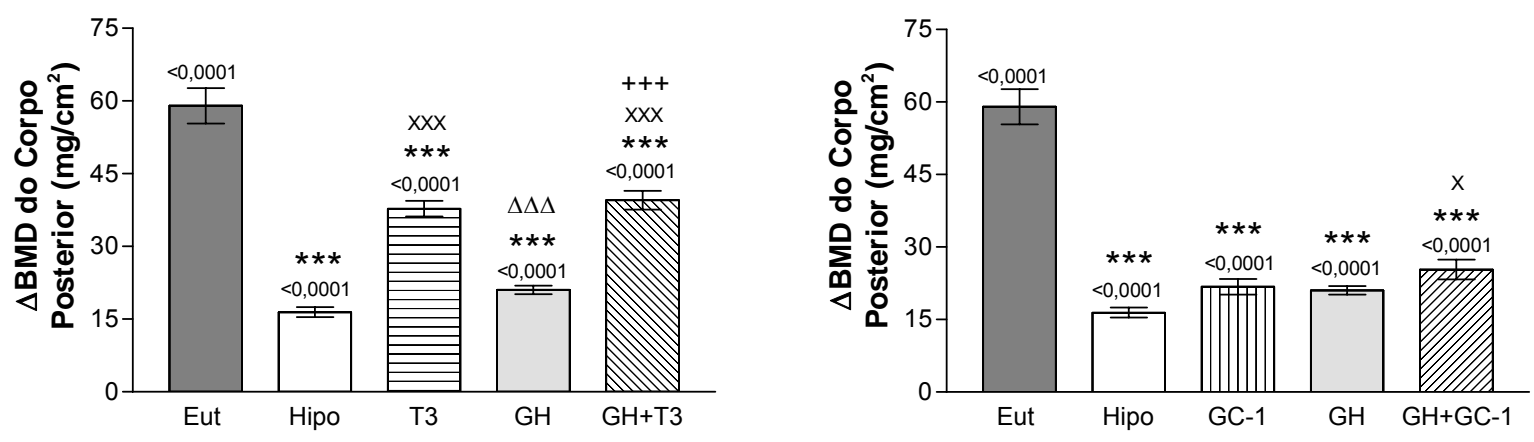

Figura 8: Efeito do tratamento com T3, GC-1 e/ou GH na variação de BMD $(\triangle B M D=B M D$ final BMD inicial) do corpo posterior de ratas jovens hipotireoideas. Os animais receberam diariamente injeções de GH sozinho ou em combinação com T3 (A) ou com GC-1 (B). Todos os valores são expressos em média \pm EPM ( $n=6-8$ por grupo). $P<0,001$ (ANOVA). ${ }^{* *}$ $p<0,001$ versus Eut; $x p<0,05$ e $x x x p<0,001$ versus Hipo; $\Delta \Delta \Delta p<0,001$ versus T3; +++ $\mathrm{p}<0,001$ versus $\mathrm{GH}$ (Student-Newman-Keuls). Os valores sobre as barras indicam a significância estatística da variação do BMD do corpo posterior ao longo do estudo dentro do próprio grupo por teste t-pareado.

O $\triangle \mathrm{BMD}$ das vértebras lombares (L2-L5) é mostrado na Fig. 9. Assim como no corpo posterior, o $\triangle B M D$ vertebral foi significativo em todos os grupos $(\mathrm{p}<0,05$ por teste $T$ pareado). O grupo Eut apresentou um aumento de massa óssea de 2,3 vezes em relação a seus dados iniciais. O ganho de massa óssea deste grupo foi estatisticamente maior do que o de todos os outros grupos $(\mathrm{p}<0,001)$. Os grupos T3 e $\mathrm{GH}+\mathrm{T} 3$ apresentaram um ganho de massa óssea nas vértebras lombares de 2,1 e 2,4 vezes maiores do que o ganho de BMD apresentado pelos animais hipotireoideos, respectivamente $(\mathrm{p}<0,001)$ (Fig. 9A). Os animais tratados com 
T3 e GH+T3 também apresentaram valores de ganho de massa óssea entre 1,5 e 1,7 vezes maior do que o mostrado pelo grupo GH $(\mathrm{p}<0,001)$. Vale ressaltar que o $\triangle \mathrm{BMD}$ do grupo $\mathrm{GH}+\mathrm{T} 3$ foi levemente, mas significativamente maior do que o grupo T3 $(\mathrm{p}<0.05)$. Os tratamentos com GC-1 e GH promoveram um ganho de BMD aproximadamente 1,5 vezes em relação a seus dados basais, sendo esses valores 1,4 vezes maiores do que os valores mostrados pelo grupo Hipo $(\mathrm{p}<0,05)$ (Fig. 9B). O ganho de massa óssea do grupo GH+GC-1 foi 1,7 vezes maior do que o grupo Hipo $(\mathrm{p}<0,001)$. Os valores do ganho de BMD dos grupos GC-1, GH e GH+GC-1 não foram significativamente diferentes entre si.
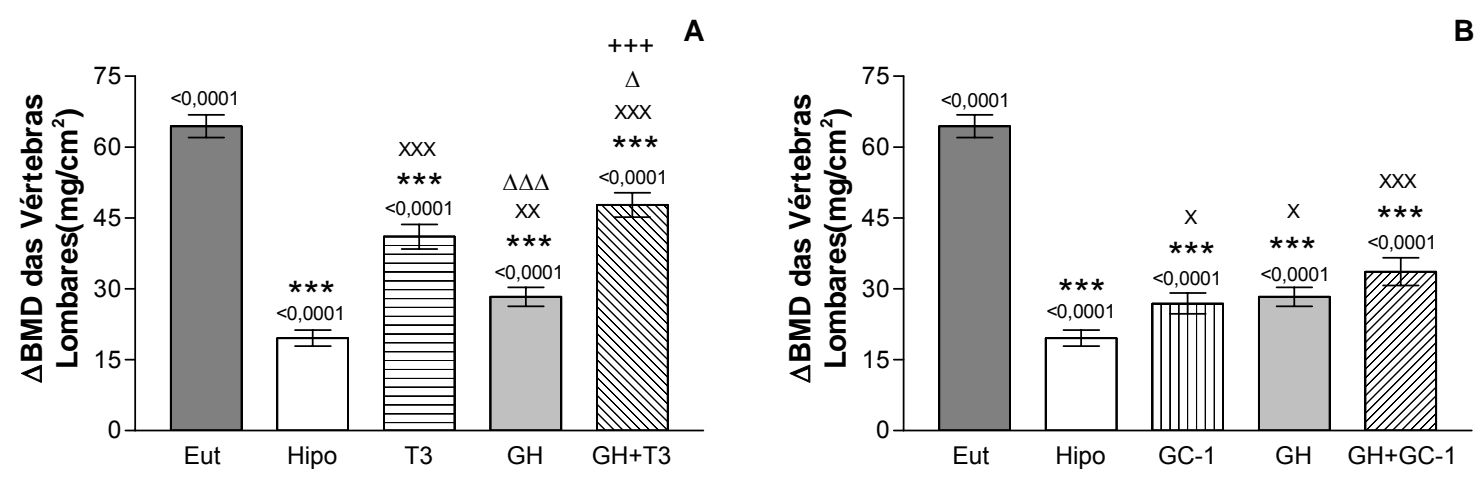

Figura 9: Efeito do tratamento com T3, GC-1 e/ou GH na variação de BMD ( $\triangle \mathrm{BMD}=\mathrm{BMD}$ final BMD inicial) das vértebras lombares (L2-L5) de ratas jovens hipotireoideas. Os animais receberam diariamente injeções de GH sozinho ou em combinação com T3 (A) ou com GC-1 (B). Todos os valores são expressos em média \pm EPM ( $n=6-8$ por grupo). $P<0,001$ (ANOVA). ${ }^{* * *} p<0,001$ versus Eut; $x p<0,05, x x p<0,01$ e xxx $p<0,001$ versus Hipo; $\Delta$ $p<0,05$ e $\Delta \Delta \Delta p<0,001$ versus T3; +++ $p<0,001$ versus $G H$ (Student-Newman-Keuls). Os valores sobre as barras indicam a significância estatística da variação do BMD vertebral ao longo do estudo dentro do próprio grupo por teste t-pareado.

O ganho de BMD do fêmur total (Fig. 10A e 10B), assim como para as vértebras lombares e corpo posterior, foi significativo para todos os grupos $(\mathrm{p}<0,05$ por teste $\mathrm{T}$ pareado). O BMD final do fêmur do grupo Eut foi 2,4 vezes maior do que os valores basais, sendo que o $\triangle B M D$ deste grupo foi significativamente maior do que o de todos os outros grupos $(\mathrm{p}<0,001)$. Os grupos tratados com T3 e GH+T3 apresentaram um ganho de BMD de aproximadamente 2,0 vezes em relação aos dados iniciais. Este aumento foi aproximadamente 3,0 vezes maior do que o apresentado pelo grupo Hipo $(\mathrm{p}<0,001)$ (Fig. 10A). O ganho de massa óssea no fêmur dos animais dos grupos GC-1, GH e GH+GC-1 foram 1,6, 1,8 e 1,9 vezes maior do que o ganho apresentado pelos animais hipotireoideos, respectivamente ( $\mathrm{p}<0,01$ versus $\mathrm{GC}-1$ e $\mathrm{GH}, \mathrm{p}<0,001$ versus $\mathrm{GH}+\mathrm{GC}-1$ ) (Fig. 10B). Os valores destes grupos não diferem entre si. 
As Fig. 10C a 10H mostram o ganho de massa óssea nas regiões proximal, média e distal do fêmur. O grupo Hipo apresentou ganho de BMD entre 3,7 e 5,6 vezes menor do que o grupo Eut em todas as regiões do fêmur $(\mathrm{p}<0,001)$. Os grupos T3 e GH+T3 mostraram $\triangle \mathrm{BMD}$ entre 2,5 e 3,0 vezes maior do que o grupo Hipo ( $\mathrm{p}<0,001)$, e entre 1,5 e 2,0 vezes maior do que o grupo GH (p<0,001). O grupo GC-1 apresentou um maior ganho de BMD no terço distal e média do fêmur em comparação ao Hipo $(\mathrm{p}<0,05)$. O efeito do GH foi mais proeminente na região média do fêmur. O ganho de massa óssea no terço médio foi de 2,1 e 2,6 vezes maior nos grupos GH e GH+GC-1, respectivamente, em relação do grupo Hipo $(\mathrm{p}<0,001)$. 
A

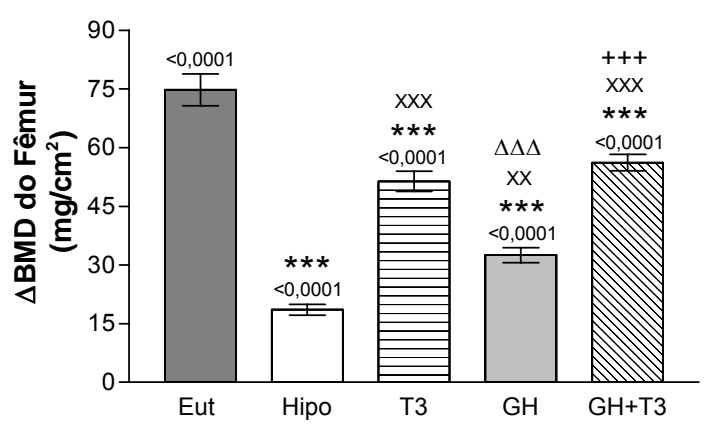

C

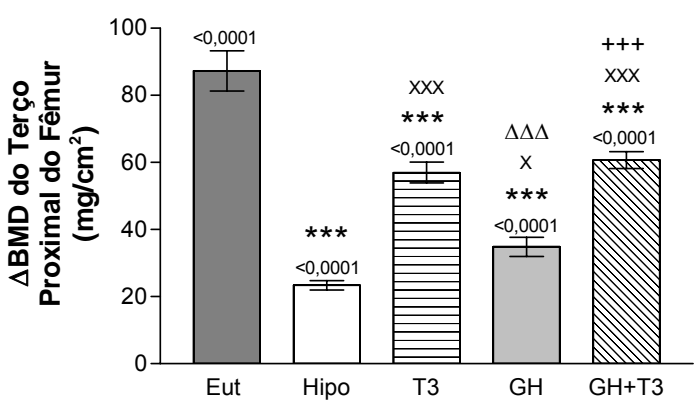

E

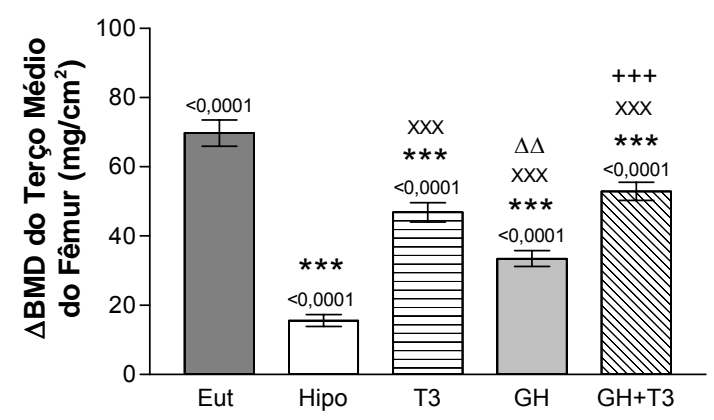

G

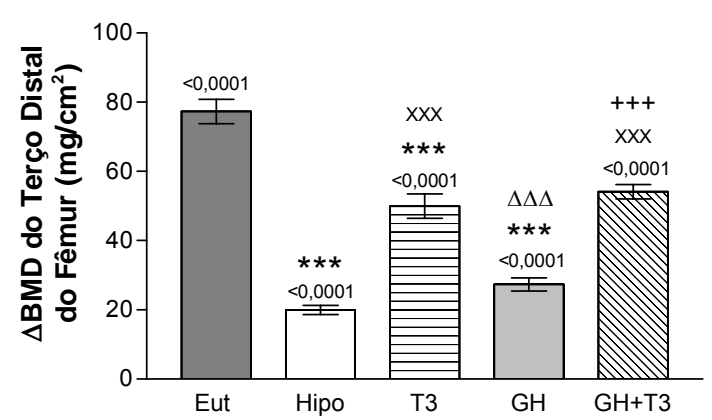

B

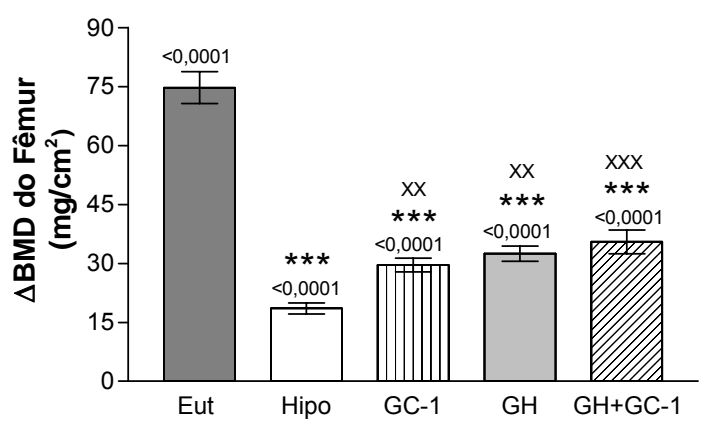

D
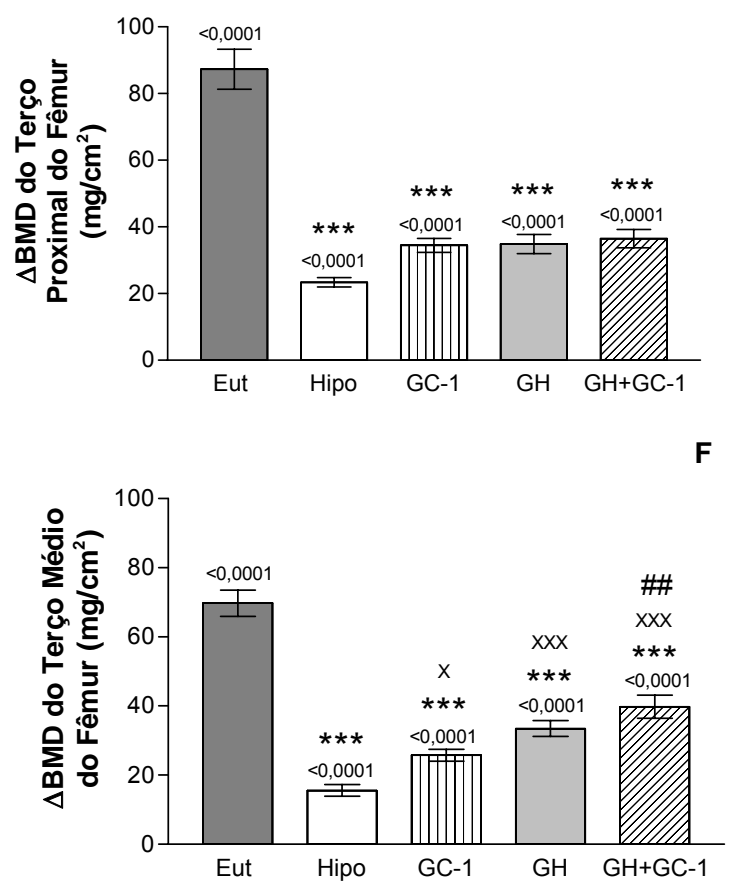

H

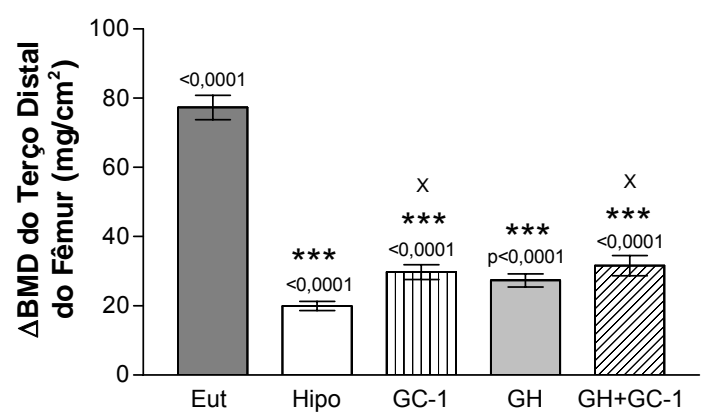

Figura 10: Efeito do tratamento com T3, GC-1 e/ou GH na variação de BMD ( $\triangle \mathrm{BMD}=\mathrm{BMD}$ final BMD inicial) do fêmur, e suas regiões, de ratas jovens hipotireoideas. Os animais receberam diariamente injeções de $\mathrm{GH}$ sozinho ou em combinação com T3 (A, C, E e G) ou com GC-1 (B, D, $\mathbf{F}$ e G). Todos os valores são expressos em média \pm EPM ( $n=6-8$ por grupo). $P<0,001$ (ANOVA). ${ }^{* * *} p<0,001$ versus Eut; $x p<0,05, x x p<0,01$ e $x x x p<0,001$ versus Hipo; $\Delta \Delta p<0,01$ e $\Delta \Delta \Delta p<0,001$ versus T3; \#\# $p<0,01$ versus GC-1; +++ $p<0,001$ versus GH, por Student-Newman-Keuls. Os valores sobre as barras indicam a significância estatística da variação do BMD ao longo do estudo dentro do próprio grupo por teste t-pareado. 
O efeito do tratamento com T3, GC-1 e/ou GH no $\triangle \mathrm{BMD}$ da tíbia é mostrado na Fig. 11. O grupo Eut apresentou BMD final 2,1 vezes maior do que o inicial e o seu $\triangle B M D$ foi significativamente diferente do apresentado pelos outros grupos $(\mathrm{p}<0,001)$. O ganho de BMD dos animais dos grupos T3 e GH+T3 foi aproximadamente 2,3 e 2,4 vezes maior do que o do grupo Hipo, respectivamente $(\mathrm{p}<0,001)$ (Fig. 11A). Esses dois grupos tratados com T3 também apresentaram ganho de BMD 1,7 vezes mais do que o grupo $G H(p<0,001)$. Não houve diferença estatística entre o $\triangle \mathrm{BMD}$ dos grupos Hipo, GC-1 e GH. Por outro lado, o grupo GH+GC-1 apresentou $\triangle \mathrm{BMD}$ significativamente maior do que o Hipo (1,6 vezes, $\mathrm{p}<0,01$ ) (Fig. 11B). Os animais do grupo GH+GC-1 mostraram um ganho de BMD 20\% maior do que os grupos GC-1 e GH, apesar de não serem estatisticamente diferentes.

A Fig. 11C a 11H mostra o ganho de massa óssea nas regiões proximal, média e distal da tíbia. Os grupos T3 e GH+T3 apresentaram ganho de BMD entre 2,1 e 2,8 vezes maior do que o ganho do grupo Hipo $(\mathrm{p}<0,001)$ e 1,5 e 1,9 vezes maior do que o do $\mathrm{GH}(\mathrm{p}<0,001)$, respectivamente. O tratamento com GC-1 promoveu um maior ganho de massa óssea, em relação ao grupo Hipo, no terço proximal e médio da tíbia (1,5 vezes, $\mathrm{p}<0,05)$. O ganho de BMD apresentado pelos animais tratados com GH foi estatisticamente maior do que o do grupo Hipo apenas no terço médio da tíbia $(1,6$ vezes, $\mathrm{p}<0,05)$ (Fig. 11F). Por outro lado, o grupo $\mathrm{GH}+\mathrm{GC}-1$ apresentou um $\triangle \mathrm{BMD}$ significativamente maior do que o grupo Hipo (entre 1,5 e 2,0 vezes) no terço proximal, médio e distal da tíbia. Além disso, o efeito do tratamento com GH+GC-1 no ganho de massa óssea foi estatisticamente maior do que o do GC-1 ou GH apenas na região distal da tíbia $(\mathrm{p}<0,05)$. 

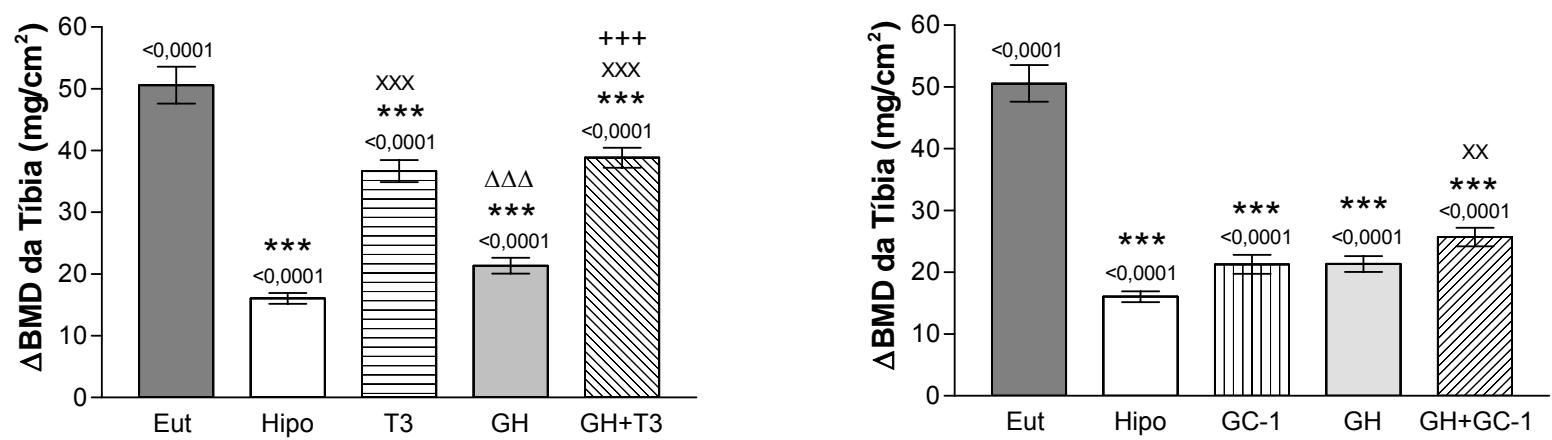

C
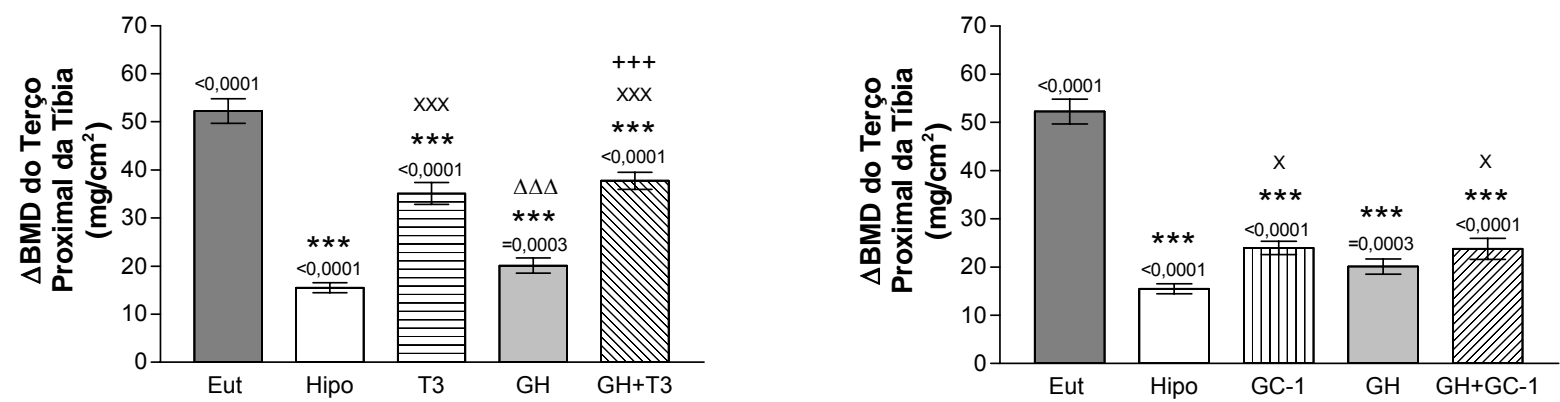

E

F
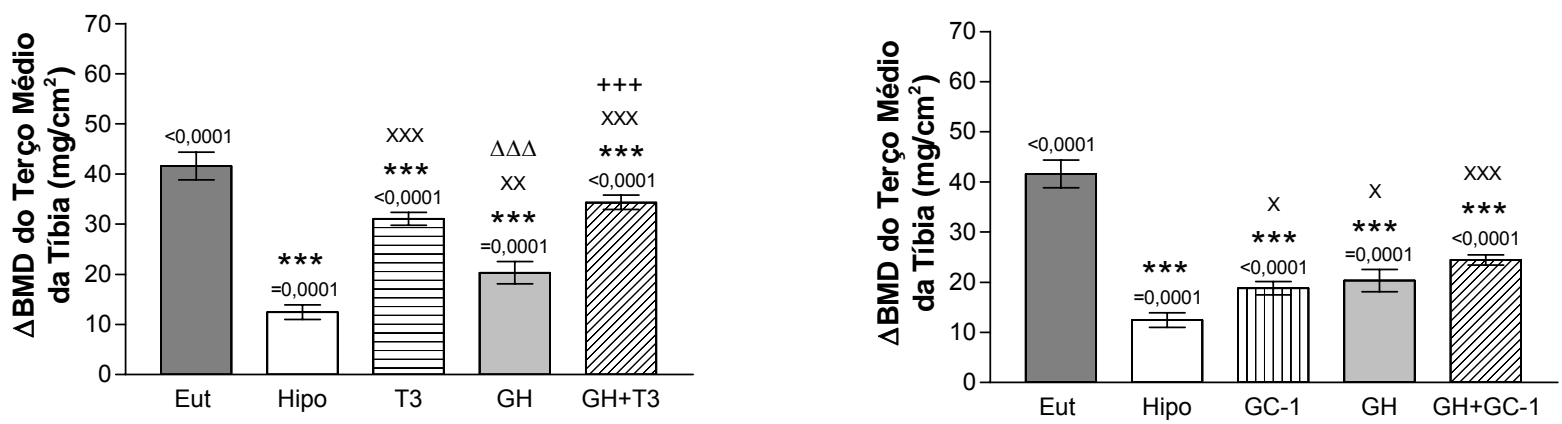

G

H
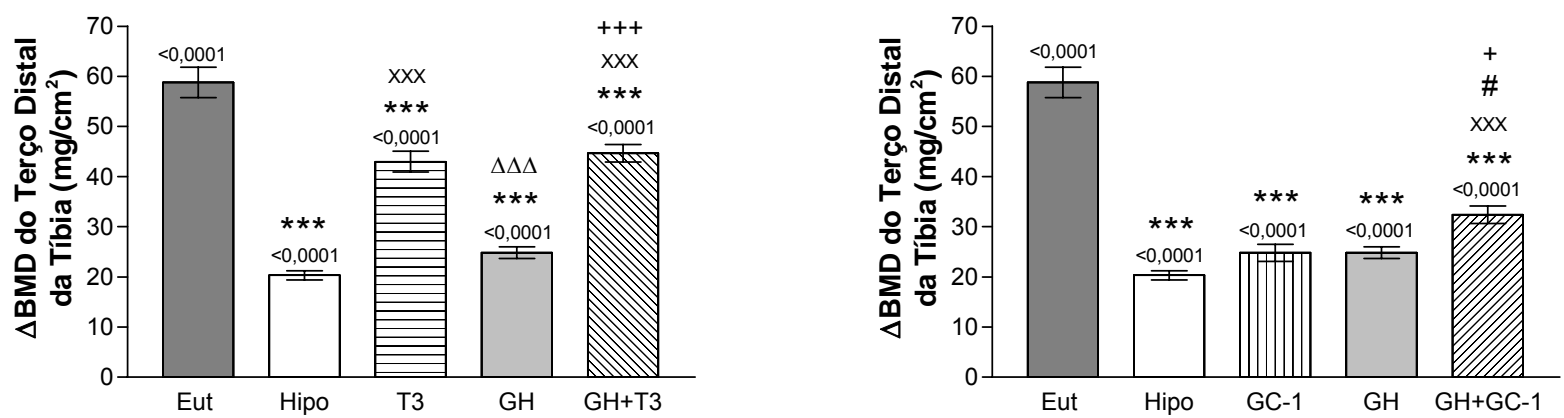

Figura 11: Efeito do tratamento com T3, GC-1 e/ou GH na variação de BMD ( $\triangle \mathrm{BMD}=\mathrm{BMD}$ final BMD inicial) da tíbia, e suas regiões, de ratas jovens hipotireoideas. Os animais receberam diariamente injeções de $\mathrm{GH}$ sozinho ou em combinação com T3 (A, C, E e G) ou com GC-1 (B, D, F e H). Todos os valores são expressos em médiatEPM ( $\mathrm{n}=6-8$ por grupo). $P<0,001$ (ANOVA). ${ }^{* * *} p<0,001$ versus Eut; $x p<0,05, x x p<0,01$ e $x x x p<0,001$ versus Hipo; $\Delta \Delta \Delta p<0,001$ versus T3; $+p<0,05$ e $+++p<0,001$ versus $G H$, por StudentNewman-Keuls. Os valores sobre as barras indicam a significância estatística da variação do BMD ao longo do estudo dentro do próprio grupo por teste t-pareado. 


\subsubsection{Teste Biomecânico}

Os efeitos do tratamento com T3, GC-1 e/ou GH nos parâmetros biomecânicos da tíbia são mostrados na Fig. 12. O hipotireoidimo causou uma diminuição significativa, entre 41\% e 57\%, na carga máxima, rigidez, resiliência e tenacidade em comparação aos animais eutireoideos $(\mathrm{p}<0,001)$.

O tratamento com T3 aumentou a carga máxima (Fig. 10A) e a rigidez óssea (Fig. 10C) em $46 \%$ e 49\%, respectivamente, em relação ao grupo Hipo ( $<<0,001$ ). Do mesmo modo, a carga máxima e a rigidez óssea do grupo T3 foram significativamente maiores do que as do grupo GH em 14\% e 34\%, respectivamente. Enquanto que a carga máxima dos animais tratados com GC-1, GH ou GH+GC-1 foi significativamente maior do que a do grupo Hipo (33\%, 25\%, 43\%, respectivamente), a rigidez óssea não foi afetada por esses tratamentos (Fig. 10B e 10D). O tratamento com GH+T3 promoveu um aumento de 71\% e 74\% na carga máxima (Fig. 10A) e na rigidez (Fig. 10C), respectivamente, em relação ao grupo Hipo. Além disso, a carga máxima e a rigidez do grupo GH+T3 foram estatisticamente maiores do que as dos grupos T3 (17\%) e GH (entre 36\% - 43\%).

O grupo T3 apresentou aumento na resiliência óssea de 43\% em relação ao grupo Hipo, entretanto esta diferença não foi significativa (Fig. 12E). Por outro lado, os tratamentos com GC-1, GH ou GH+GC-1 promoveram um aumento significativo, entre 15\% e 30\%, nesse parâmetro biomecânico em comparação ao grupo Hipo (Fig. 12F). Já o grupo GH+T3 mostrou resiliência estatisticamente maior do que a do grupo Hipo (87\%, p<0,001), T3 (31\%, $\mathrm{p}<0,05)$ e $\mathrm{GH}(63 \%, \mathrm{p}<0,01)$.

A administração de T3, GC-1 e/ou GH não promoveram aumentos significativos na tenacidade, contudo, os tratamentos com GH+T3 e GH+GC-1 aumentaram a tenacidade em 82\% e 59\% em relação ao grupo Hipo ( $\mathrm{p}<0,001)$ (Fig. 12G e 12H, respectivamente). 

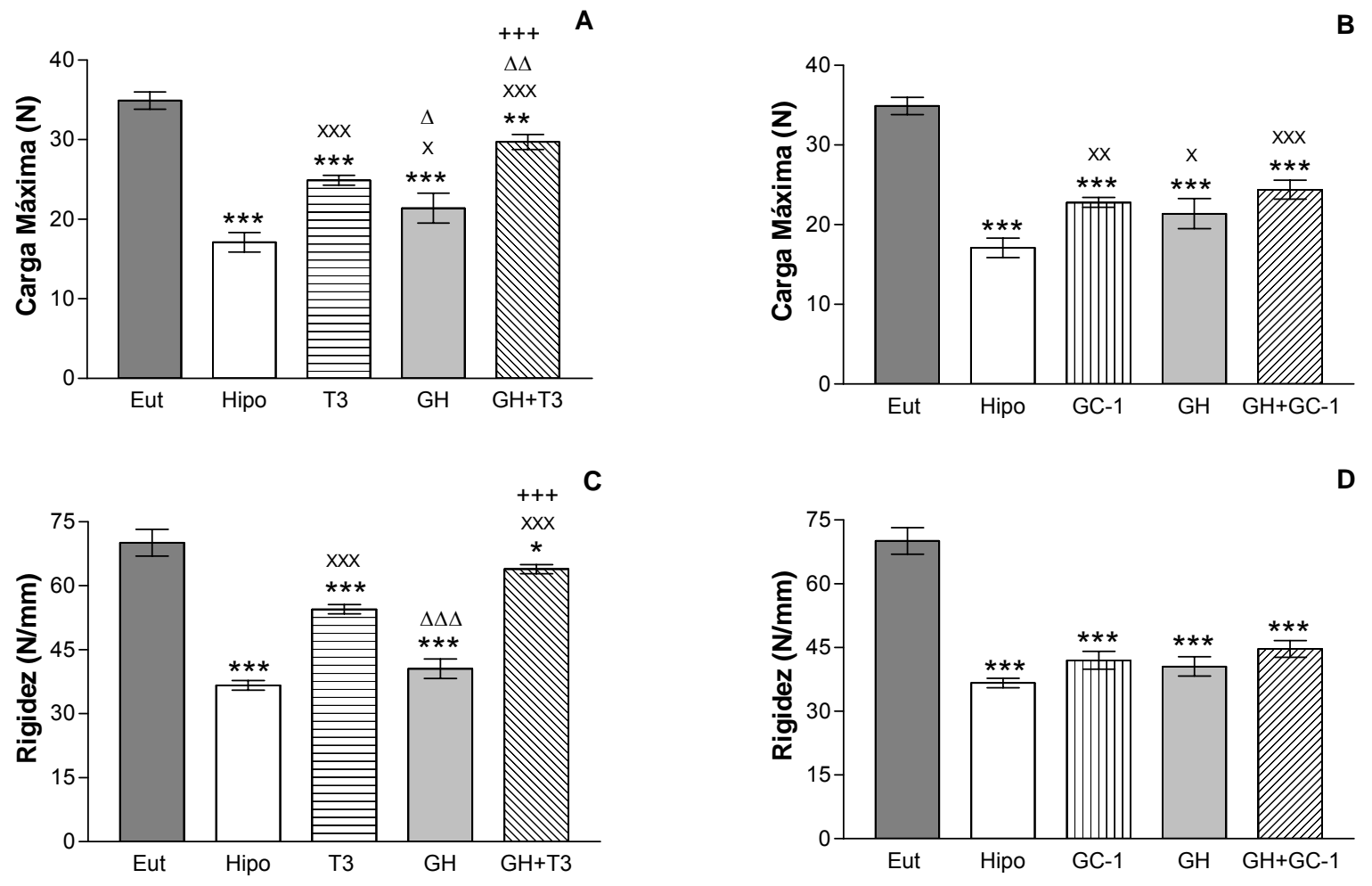

E
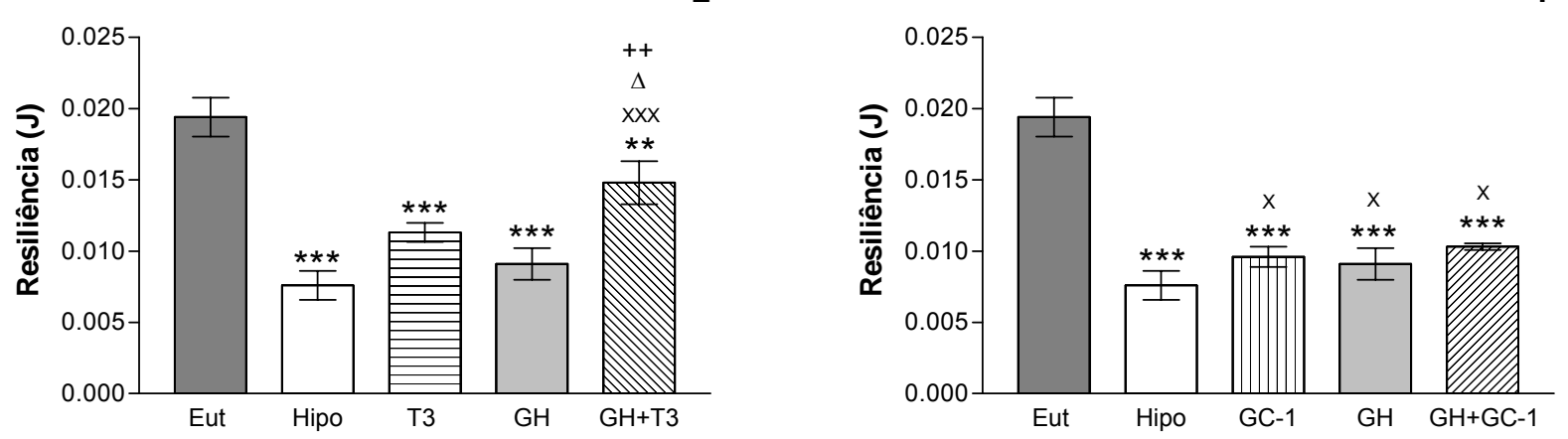

G
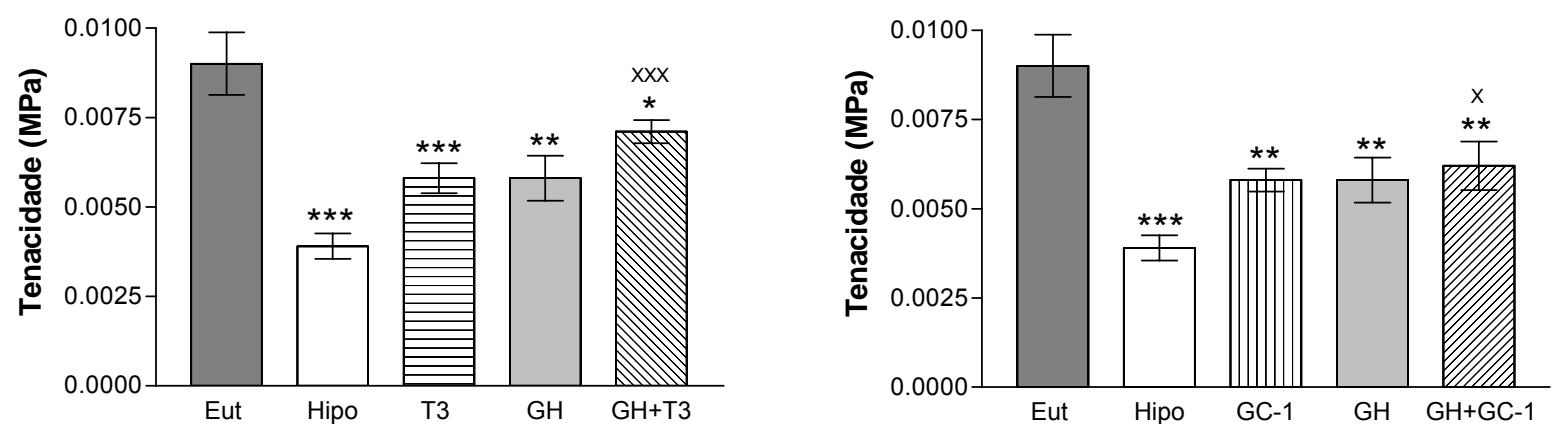

Figura 12: Efeito do tratamento com T3, GC-1 e/ou GH nos parâmetros biomecânicos da tíbia de ratas jovens hipotireoideas. (A e B) Carga Máxima. (C e D) Rigidez. (E e F) Resiliência. ( $\mathbf{G}$ e H) Tenacidade. Os animais receberam diariamente injeções de $\mathrm{GH}$ sozinho ou em combinação com T3 (A, C, E e G) ou com GC-1 (B, D, F e H). Todos os valores são expressos em médiatEPM ( $n=6-8$ por grupo). $P<0,001$ (ANOVA). * $p<0,05,{ }^{* *} p<0,01$ e ${ }^{* * *} p<0,001$ versus Eut; $x p<0,05, x x p<0,01$ e xxx $p<0,001$ versus Hipo; $\Delta p<0,05, \Delta \Delta$ $p<0,01$ e $\Delta \Delta \Delta p<0,001$ versus T3; ++ $p<0,01$ e $+++p<0,001$ versus $G H$, por StudentNewman-Keuls. 


\subsubsection{Histologia e Morfometria da Lâmina Epifisial do Fêmur}

As Fig. 13, 14, 15 e 16 mostram o efeito do tratamento de ratas hipotireoideas com T3, GC-1 e/ou GH na morfologia da lâmina epifisial (LE) e das suas zonas de reserva (ZR), proliferativa (ZP) e hipertrófica (ZH). Considerando a espessura da lâmina epifisial e de suas regiões, a zona de reserva foi a menos afetada. Apenas os animais tratados com GH apresentaram espessura da ZR entre $40 \%$ e $80 \%$ maior do que dos outros grupos $(\mathrm{p}<0,01$ versus GC-1 e $\mathrm{p}<0,05$ versus todos os outros grupos) (Fig. 13C e 13D).

Nota-se que o hipotireoidismo promoveu uma redução significativa na espessura da LE (41\%), ZP (47\%) e ZH (42\%) em relação aos animais eutireoideos (Fig. 13), assim como da área da lâmina epifisial (34\%) (Fig. 14). Já o tratamento com T3 reverteu quase que completamente os danos na LE causado pelo hipotireoidismo. O grupo T3 apresentou espessura da LE, ZP e ZH (Fig.13) e área da LE (Fig. 14) 47\%, 50\%, 60\% e 36\% maiores do que os valores apresentados pelo grupo Hipo, respectivamente. Desses parâmetros, apenas a espessura da ZP foi revertida parcialmente pelo tratamento com T3 (Fig. 13E). Todos os outros parâmetros foram revertidos completamente pelo tratamento com T3. Por outro lado, o tratamento com o GC-1 não afetou a área e a espessura da LE em comparação com o grupo Hipo, bem como a espessura da ZP e ZH (Fig. 13 e 14).

O tratamento com GH sozinho foi aquele que promoveu os efeitos mais evidentes na lâmina epifisial (Fig. 13 e 14). Os animais tratados com GH apresentaram espessura da LE, ZP e ZH e área da LE significativamente maiores do que a dos grupos Hipo (entre 2,1 e 2,5 vezes) e T3 (58\%, 51\%, 47\% e 36\%, respectivamente). Além disso, área da LE e a espessura da LE e da ZH do grupo GH foi 37\%, 28\%, 46\% maior, respectivamente, do que do grupo Eut. Já a associação do GH com o T3 (grupo GH+T3) limitou o aumento excessivo da área da LE e da espessura da LE e ZH induzido pelo GH, permitindo que todos esses valores igualassem-se àqueles dos grupos Eut ou T3 (Fig. 13 e 14). É digno de nota que a combinação do GC-1 com o GH apenas limitou o aumento promovido pelo GH na espessura da ZR (Fig 13D). 

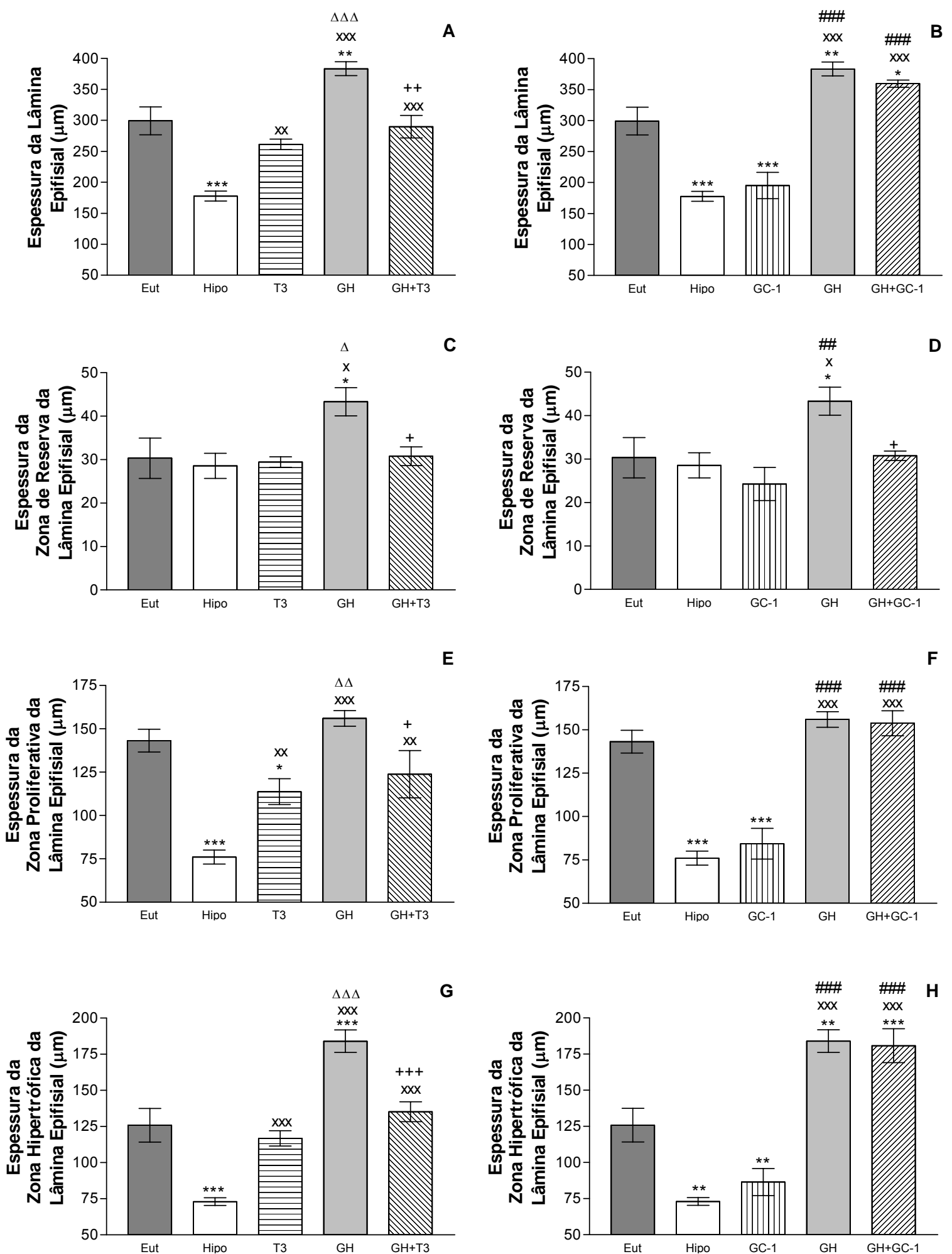

Figura 13: Efeito do tratamento com T3, GC-1 e/ou GH na espessura da lâmina epifisial distal do fêmur de ratas jovens hipotireoideas. (A e B) Espessura da lâmina epifisial (LE). (C e D) Espessura da Zona de Reserva (ZR). (E e F) Espessura da Zona Proliferativa (ZP). (G e H) Espessura da Zona Hipertrófica $(\mathrm{ZH})$. Os animais receberam diariamente injeções de GH sozinho ou em combinação com T3 (A, C, E e G) ou com GC-1 (B, D, F e H). Todos os valores são expressos como média \pm EPM $(n=4)$. $P<0,001$ (ANOVA). * $p<0,05$, ** $p<0,01$ e $^{* * *} p<0,001$ versus Eut; $x p<0,01, x x p<0,01$ e $x x x p<0,001$ versus Hipo; $\Delta$ $p<0,05, \Delta \Delta p<0,01$ e $\Delta \Delta \Delta p<0,001$ versus T3; \#\# $p<0,01$ e \#\#\# $p<0,001$ versus $G C-1 ;+$ $p<0,05,++p<0,01$ e $+++p<0,001$ versus $G H$ (Student-Newman-Keuls). 

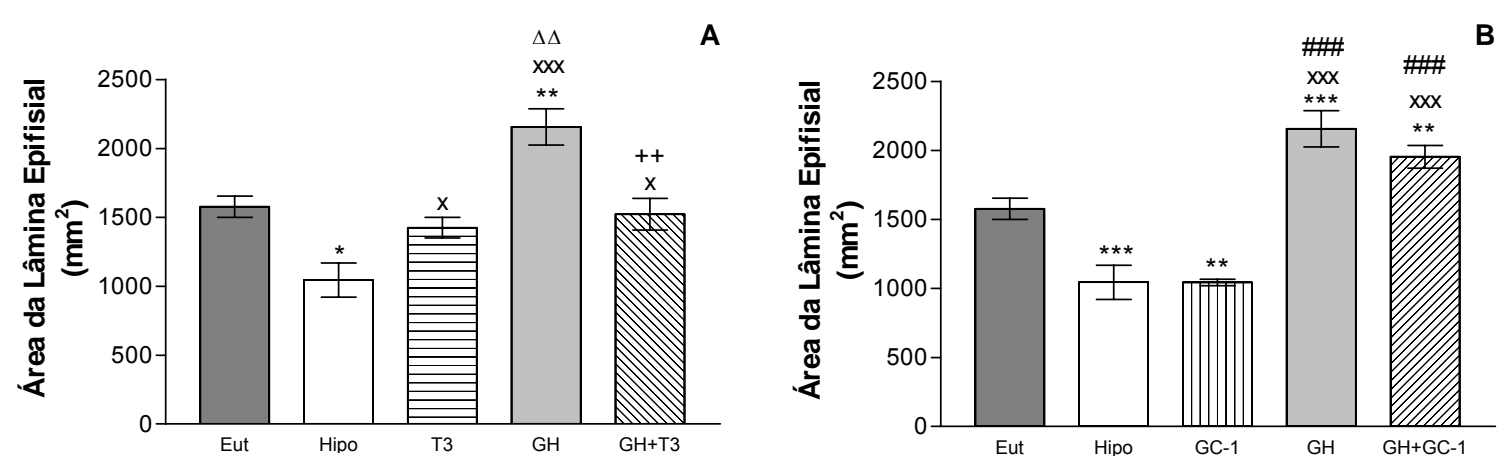

Figura 14: Efeito do tratamento com T3, GC-1 e/ou GH na área da lâmina epifisial distal do fêmur de ratas jovens hipotireoideas. Os animais receberam diariamente injeções de $\mathrm{GH}$ sozinho ou em combinação com T3 (A) ou com GC-1 (B). Todos os valores são expressos como médiatEPM $(n=4) . P<0,001$ (ANOVA). ${ }^{*} p<0,05,{ }^{* *} p<0,01 e^{* * *} p<0,001$ versus Eut; $x$ $p<0,01$ e $x x x p<0,001$ versus Hipo; $\Delta \Delta p<0,01 p<0,001$ versus T3; \#\#\# $p<0,001$ versus GC-1; ++ $p<0,01 p<0,001$ versus GH (Student-Newman-Keuls).

O efeito do tratamento com T3, GC-1 e/ou GH no número e organização dos condrócitos na LE e na área celular dos CH é mostrado nas Fig. 15 e 16. Pode-se observar que o hipotireoidismo alterou todos esses parâmetros. O número de $\mathrm{CP} /$ coluna e o número e área dos $\mathrm{CH}$ foram 46\%, 47\% e 25\%, respectivamente, menores no grupo Hipo em comparação ao Eut $(\mathrm{p}<0,001)$ (Fig. 15). Além disso, os condrócitos proliferativos dos animais do grupo Hipo não estavam organizados em colunas (Fig. 16). Além da organização dos CP em colunas (Fig. 16), o grupo T3 apresentou número de CP/coluna e número e área de $\mathrm{CH}$ 63\%, 73\% e 49\%, respectivamente, maiores do que do grupo Hipo ( $<<0,001$ para $\mathrm{CP} /$ coluna, $\mathrm{p}<0,01$ para $\mathrm{CH}$ ) (Fig. 15). O tratamento com GC-1, apesar de não promover organização da lâmina epifisial (Fig. 16), mostrou uma clara tendência em aumentar o número e área dos $\mathrm{CH}$ em comparação ao grupo Hipo, em 28\% e 16\%, respectivamente (Fig. 15D e F). O grupo GH apresentou um número de $\mathrm{CP} /$ coluna significativamente maior do que do grupo Hipo $(66 \%$, p<0,001) (Fig. 15A e 15B), porém a LE deste grupo não estava organizada em colunas (Fig. 16). Somandose a isso, o tratamento com GH aumentou o número de $\mathrm{CH}$ em comparação ao grupo Hipo (2,8 vezes, $\mathrm{p}<0,001)$, Eut (48\%, p<0,01) e T3 (62\%, p<0,01) (Fig. 15C), porém a área média dessas células foi apenas significativamente maior do que a do grupo Hipo $(39 \%, p<0,001)$ (Fig. 15E).

A combinação do tratamento com T3 e GH resultou em um número de $\mathrm{CP} /$ colunas semelhante ao dos grupos T3 e GH (Fig. 15A), além de organizar a LE (Fig. 16). Entretanto, a associação do T3 com o GH limitou o excessivo aumento no número de $\mathrm{CH}$ promovido pelo 
GH (Fig. 15C). O número de $\mathrm{CH}$ apresentados pelo grupo $\mathrm{GH}+\mathrm{T} 3$ foi muito próximo ao mostrado pelos animais tratados somente com T3, e significativamente menor do que o apresentado pelo grupo GH (33\%, p<0,01) (Fig. 15C). O tratamento com GH e GC-1 não alterou os efeitos promovidos pelo tratamento isolado com GH na organização (Fig. 16) e no número de CP/colunas (Fig. 15B). Porém, observa-se que o GC-1 foi capaz de limitar o aumento excessivo no número de $\mathrm{CH}$ promovido pelo GH (Fig. 15D).

A
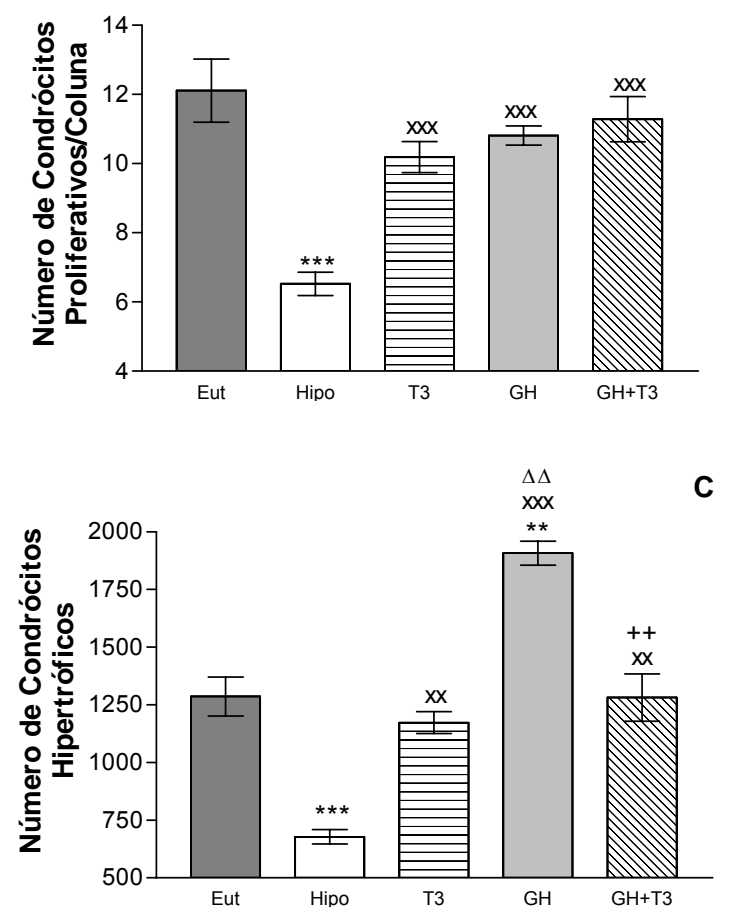

$\mathrm{E}$

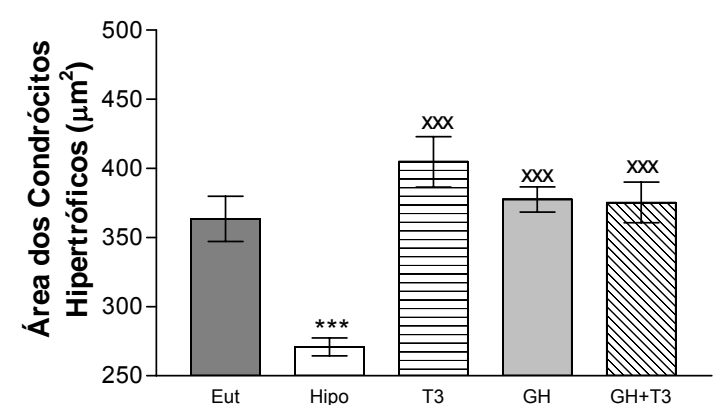

B
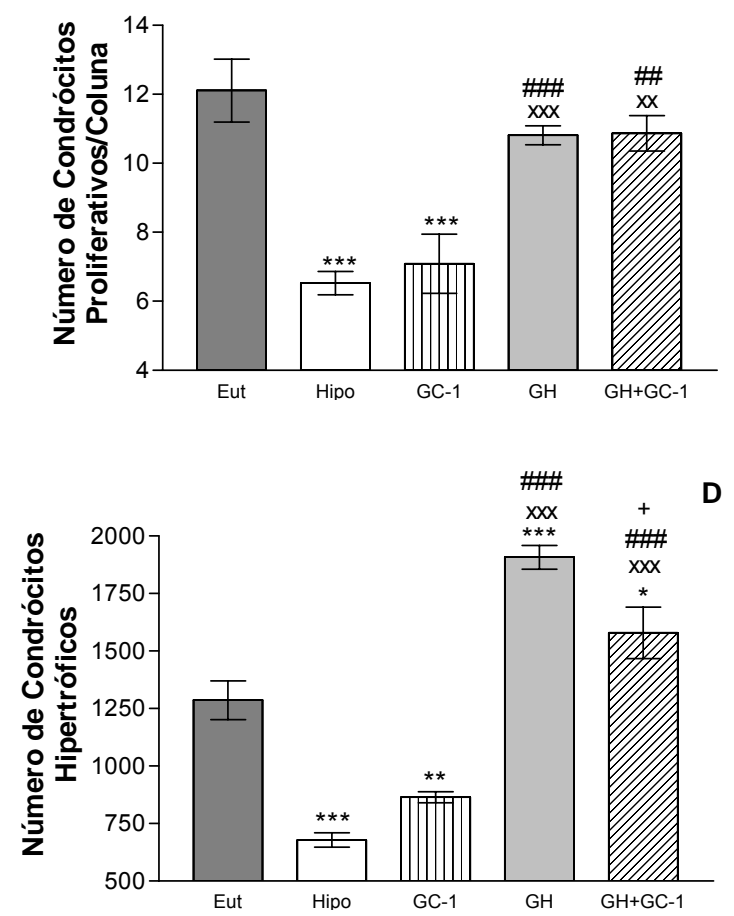

$\mathbf{F}$

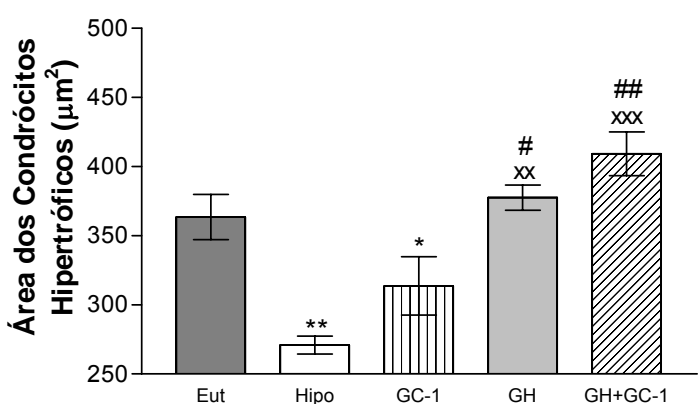

Figura 15: Efeito do tratamento com T3, GC-1 e/ou GH na morfometria da lâmina epifisial distal do fêmur de ratas jovens hipotireoideas. ( $\left.\begin{array}{lll}\mathbf{A} & \text { e } & \mathbf{B}\end{array}\right)$ Número de Condrócitos Proliferativos/Coluna. (C e D) Número de Condrócitos Hipertróficos na Lâmina Epifisial. (E e F) Área dos Condrócitos Hipertróficos. Os animais receberam diariamente injeções de GH sozinho ou em combinação com T3 (A, C e E) ou com GC-1 (B, D e F). Todos os valores são expressos como médiatEPM $(n=4)$. $P<0,001$ (ANOVA). * $p<0,05$, ${ }^{* *} p<0,01$ e *** $p<0,001$ versus Eut; $x x p<0,01$ e $x x x p<0,001$ versus Hipo; $\Delta \Delta p<0,01$ versus T3; \# $p<0,05, \# \#<0,01$ e \#\# $p<0,001$ versus $G C-1 ;+p<0,05,++p<0,01$ versus $G H$ (StudentNewman-Keuls). 

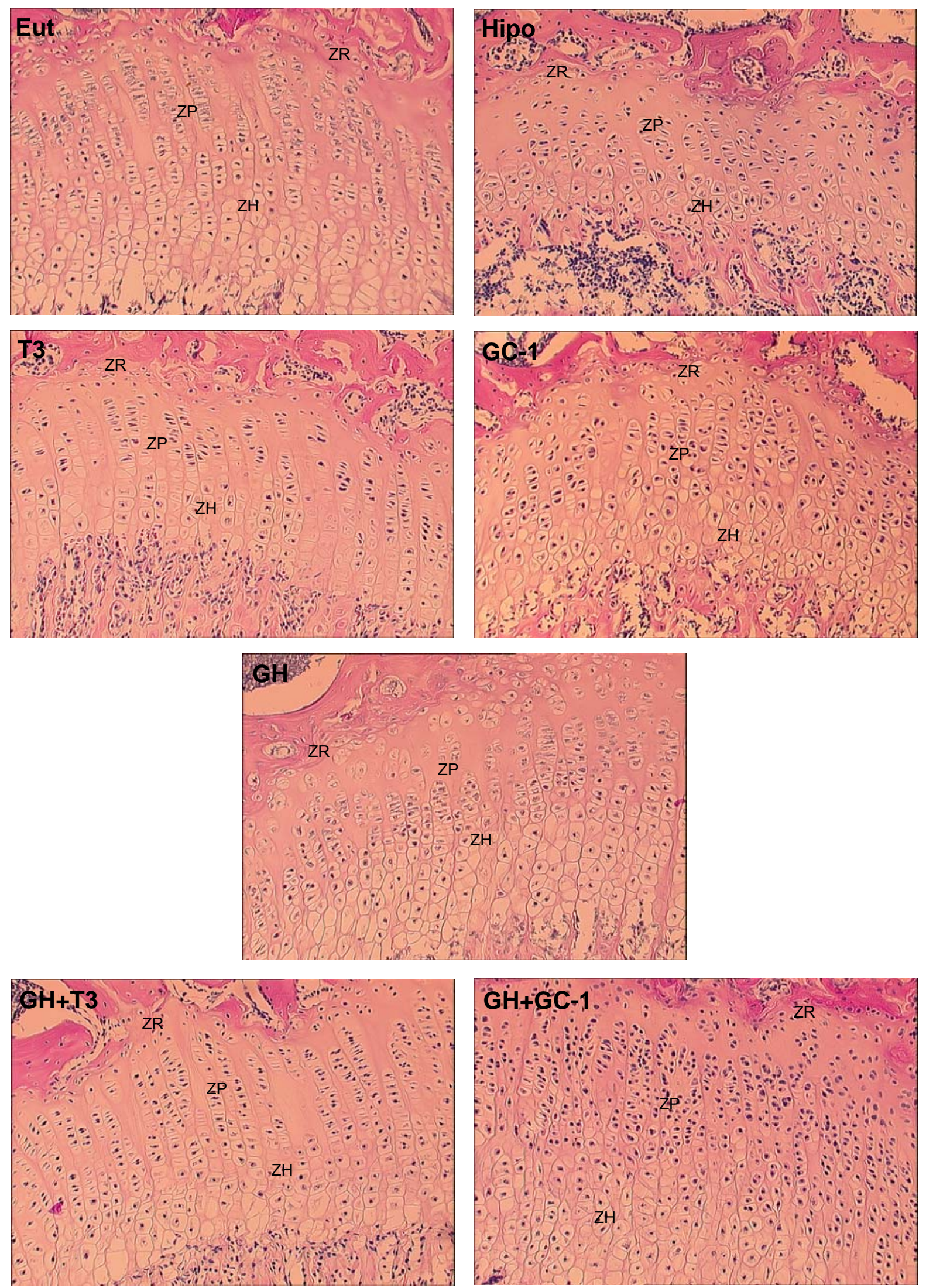

Figura 16: Efeito do tratamento com T3, GC-1 e/ou GH na lâmina epifisial de ratas hipotireoideas. Corte longitudinal do fêmur direito. ZR, zona de reserva; ZP, zona proliferativa; ZH, zona hipertrófica. Objetiva: 20x. Os cortes histológicos foram corados com hematoxilina \& eosina. 


\subsection{Experimento II}

\subsubsection{Peso Corporal}

O ganho de peso corporal dos animais durante o período experimental é mostrado na Fig. 17. Com exceção do grupo Eut, o ganho de peso não foi estatisticamente significativo por teste T-pareado (peso final versus peso inicial). O peso corporal final do grupo Eut aumentou 4,5 vezes, em relação aos seus valores basais $(\mathrm{p}<0,001)$. Ao final do estudo, o peso corporal deste grupo foi estatisticamente diferente de todos os outros grupos $(p<0,001)$. Os grupos tratados apresentaram tendência a maior aumento de peso corporal em relação ao grupo Hipo, porém não houve significância estatística.

A

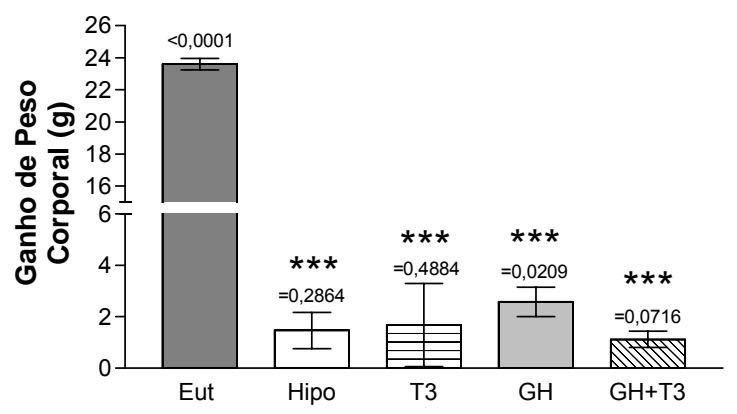

B

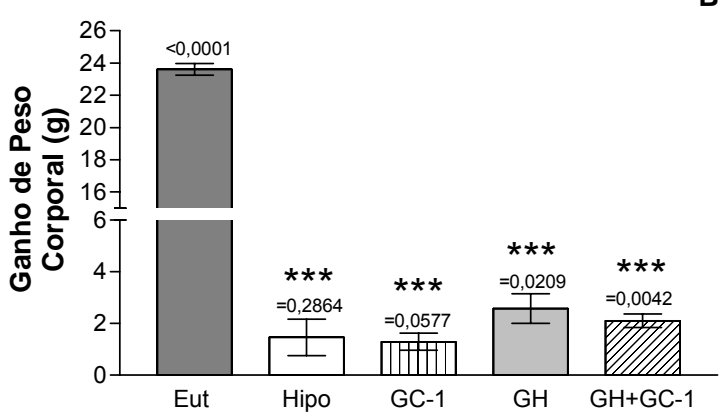

Figura 17: Efeito do tratamento com T3, GC-1 e/ou GH no ganho de peso corporal de ratos neonatos hipotireoideos. Os animais receberam diariamente injeções de $\mathrm{GH}$ sozinho ou em combinação com T3 (A) ou com GC-1 (B). Todos os valores são expressos como média \pm EPM ( $n=4$ por grupo). $P<0,001$ (ANOVA). ${ }^{* * *} p<0,001$ versus Eut (StudentNewman-Keuls). Os valores sobre as barras indicam a significância estatística da variação do peso corporal ao longo do estudo dentro do próprio grupo por teste t-pareado.

\subsubsection{Comprimento Corporal Longitudinal}

A Fig. 18 mostra o efeito do tratamento com T3, GC-1 e/ou GH no comprimento longitudinal corporal. O tratamento hormonal não causou nenhum efeito no comprimento corporal. Todos os grupos tratados apresentaram valores similares ao do observado no grupo Hipo; porém foram significativamente diferentes do grupo Eut $(\mathrm{p}<0,001)$. 
A

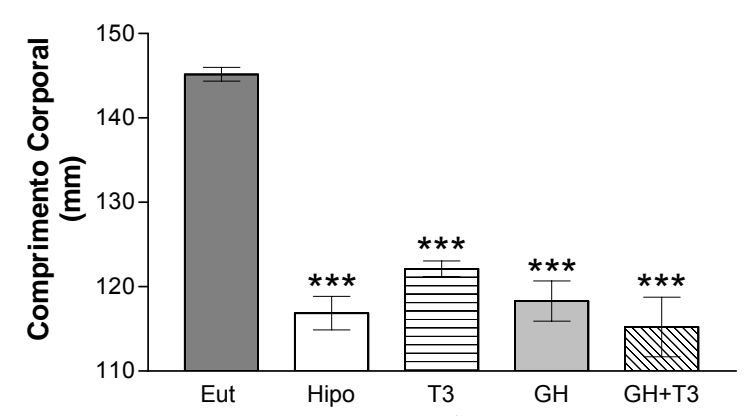

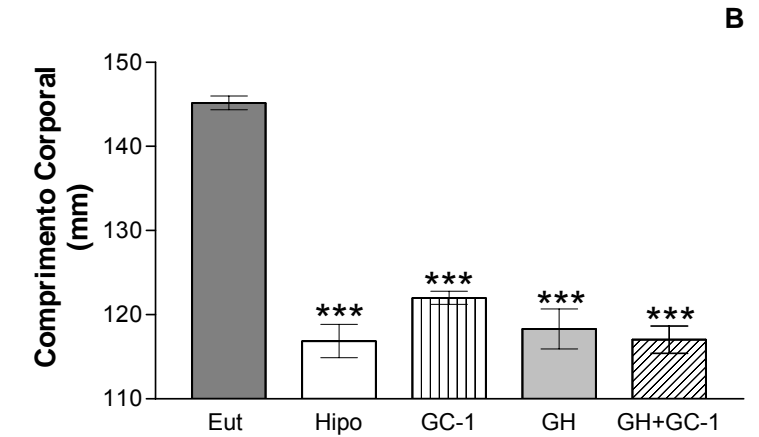

Figura 18: Efeito do tratamento com T3 e GC-1 no comprimento corporal longitudinal de ratos neonatos hipotireoideos. Os animais receberam diariamente injeções de $\mathrm{GH}$ sozinho ou em combinação com T3 (A) ou com GC-1 (B). Todos os valores são expressos como médiatEPM ( $\mathrm{n}=4$ por grupo). $\mathrm{P}<0,001$ (ANOVA). ${ }^{* * *} \mathrm{p}<0,001$ versus Eut (StudentNewman-Keuls).

\subsubsection{Análise da Ossificação Endocondral e Intramembranosa}

As Fig. 19, 20, 21 e 22 mostram os efeitos do tratamento com T3, GC-1 e/ou GH na ossificação endocondral. Como esperado, os animais Hipo apresentaram atraso generalizado nos processos de ossificação. O grupo Hipo apresentou área do centro secundário de ossificação distal do fêmur 12\% menor do que aquela do grupo Eut ( $<<0,001)$ (Fig. 19 e 20). Esse claro atraso na ossificação do fêmur também é visto em outros sítios do esqueleto, como na epífise proximal da tíbia (Fig. 20), nos ossos do tarso, nas epífises distais dos metatarsos (Fig. 21), nos ossos do carpo e nas epífises distais dos metacarpos (Fig. 22). O atraso da ossificação endocondral causado pelo hipotireoidismo foi revertido pela reposição com T3 em todas as regiões do esqueleto analisadas (Fig. 20-22). A área do centro de ossificação do fêmur do grupo T3 foi aproximadamente 2,9 vezes maior do que a apresentada pelo grupo Hipo ( $<<0,001$ ) (Fig. 19). O GC-1 claramente induziu a ossificação endocondral, entretanto, seus efeitos foram menos acentuados do que os do T3 (Fig. 19-22). A área do centro de ossificação do fêmur dos animais tratados com GC-1 foi aproximadamente 1,5 vezes maior do que aquela do grupo Hipo $(\mathrm{p}<0,05)$ (Fig. 19). O GH, quando administrado sozinho, não apresentou efeito evidente na ossificação endocondral em todos os sítios do esqueleto analisados. O tamanho dos centros de ossificação das epífises do fêmur, tíbia, metatarsos e metacarpos e dos ossos do tarso e carpo foram muito semelhantes entre os animais dos grupos GH e Hipo (Fig. 20-22). A área do centro de ossificação do fêmur do grupo tratado com GH foi $74 \%$ menor do que o centro de ossificação do grupo T3 ( $\mathrm{p}<0,001)$ e $44 \%$ menor do que o do grupo GC-1 ( $<<0,05)$ (Fig. 19). 
Observa-se, ainda, que a associação do GH com o T3 (GH+T3) não aumentou a área do centro de ossificação secundário do fêmur em relação ao grupo T3 (Fig. 19 e 20). Os valores da área do centro de ossificação do fêmur dos animais do grupo GH+T3 foram semelhantes aos valores apresentados pelo grupo T3, enquanto foram aproximadamente 3,6 vezes maiores do que os mostrados pelo grupo GH $(p<0,001)$ (Fig. 19). Por outro lado, o tratamento com GH+GC-1 promoveu um aumento significante na área do centro de ossificação do fêmur em comparação com o GC-1 (1,4 vezes, p<0,01) e com GH (2,5 vezes, $\mathrm{p}<0,001)$. Entretanto, o grupo GH apresentou área do centro de ossificação do fêmur 56\% menor do que a do grupo GC-1 $(\mathrm{p}<0,05)$ (Fig. 16 e 20). Resultados semelhantes a estes também foram encontrados em todos os outros sítios do esqueleto analisados (Fig. 20-22).

A
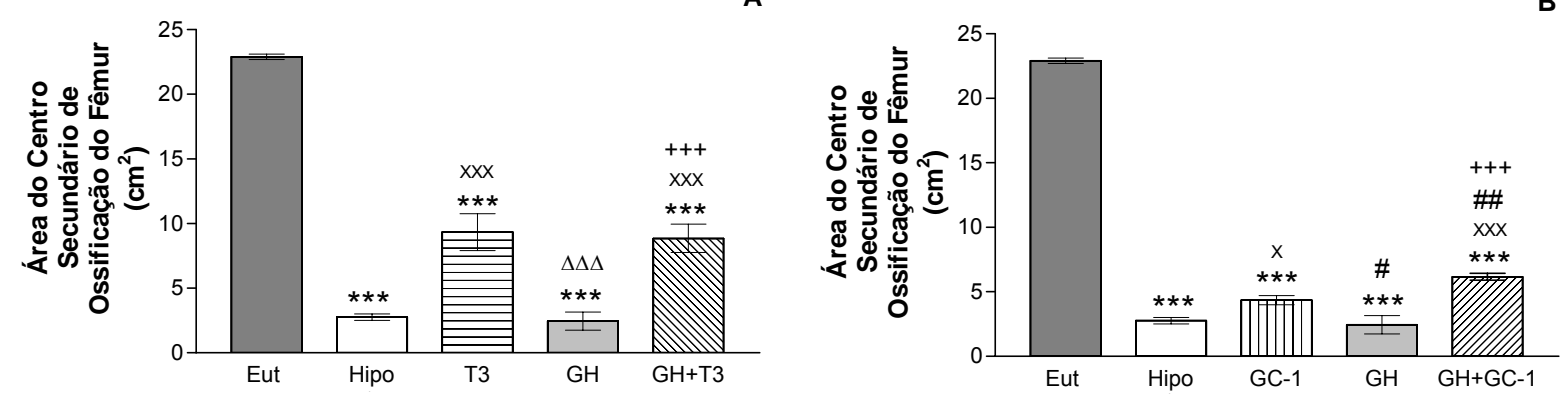

Figura 19: Efeito do tratamento com T3, GC-1 e/ou GH no centro secundário de ossificação do fêmur de ratos neonatos hipotireoideos. Os animais receberam diariamente injeções de $\mathrm{GH}$ sozinho ou em combinação com T3 (A) ou com GC-1 (B). Todos os valores são expressos em média \pm EPM ( $n=3-4$ por grupo). $P<0,001$ (ANOVA). ${ }^{* * *} p<0,001$ versus Eut; $x p<0,05$ e

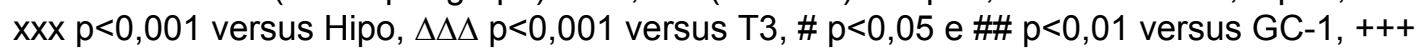
$p<0,001$ versus $G H$, por Student-Newman-Keuls. 

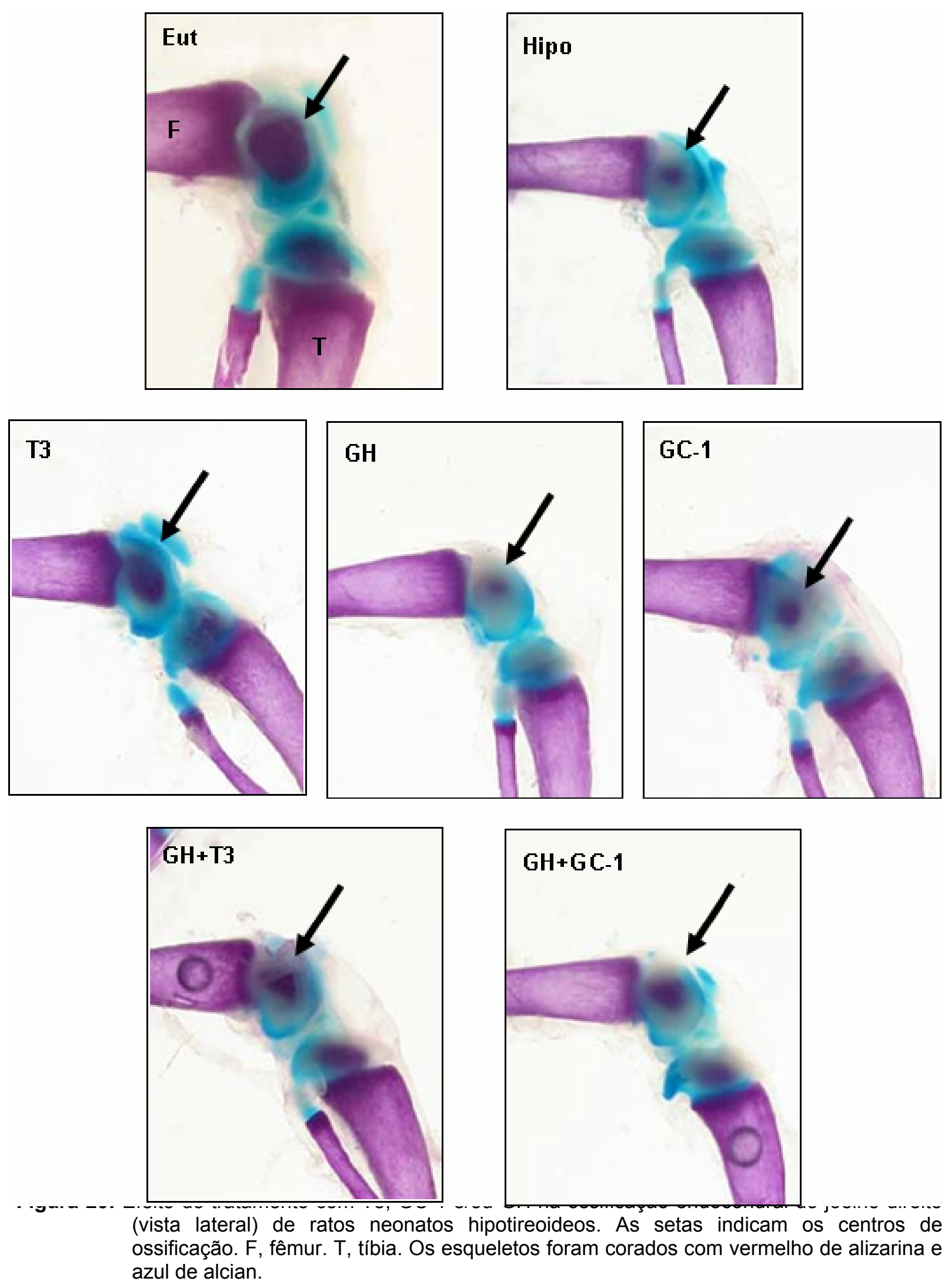


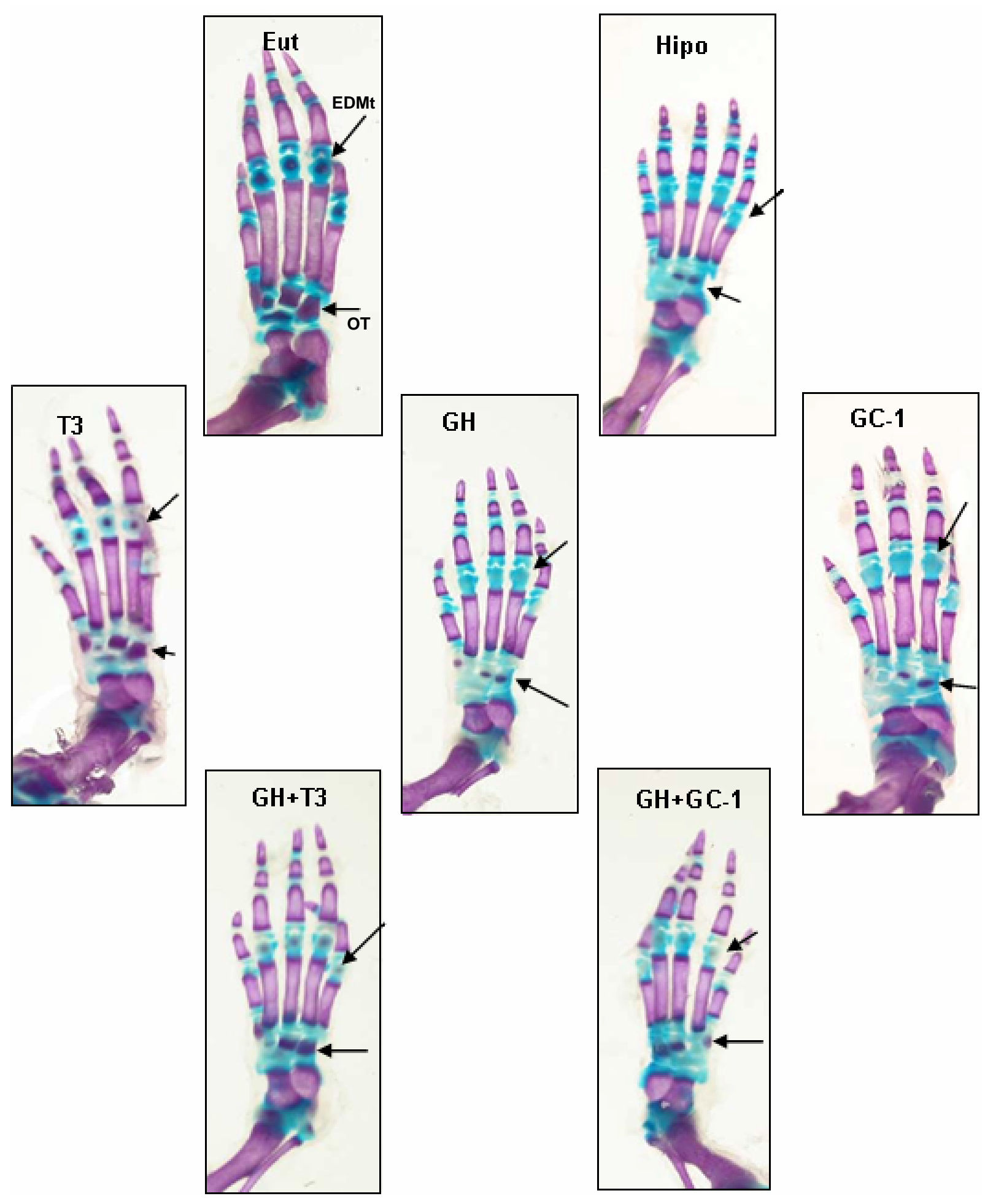

Figura 21: Efeito do tratamento com T3, GC-1 e/ou GH na ossificação endocondral da pata posterior direita (vista dorsal) de ratos neonatos hipotireoideos. As setas indicam os centros de ossificação, sendo que as setas superiores indicam as epífises distais dos metatarsos (EDMt) e as inferiores, os ossos do tarso (OT). Os esqueletos foram corados com vermelho de alizarina e azul de alcian. 


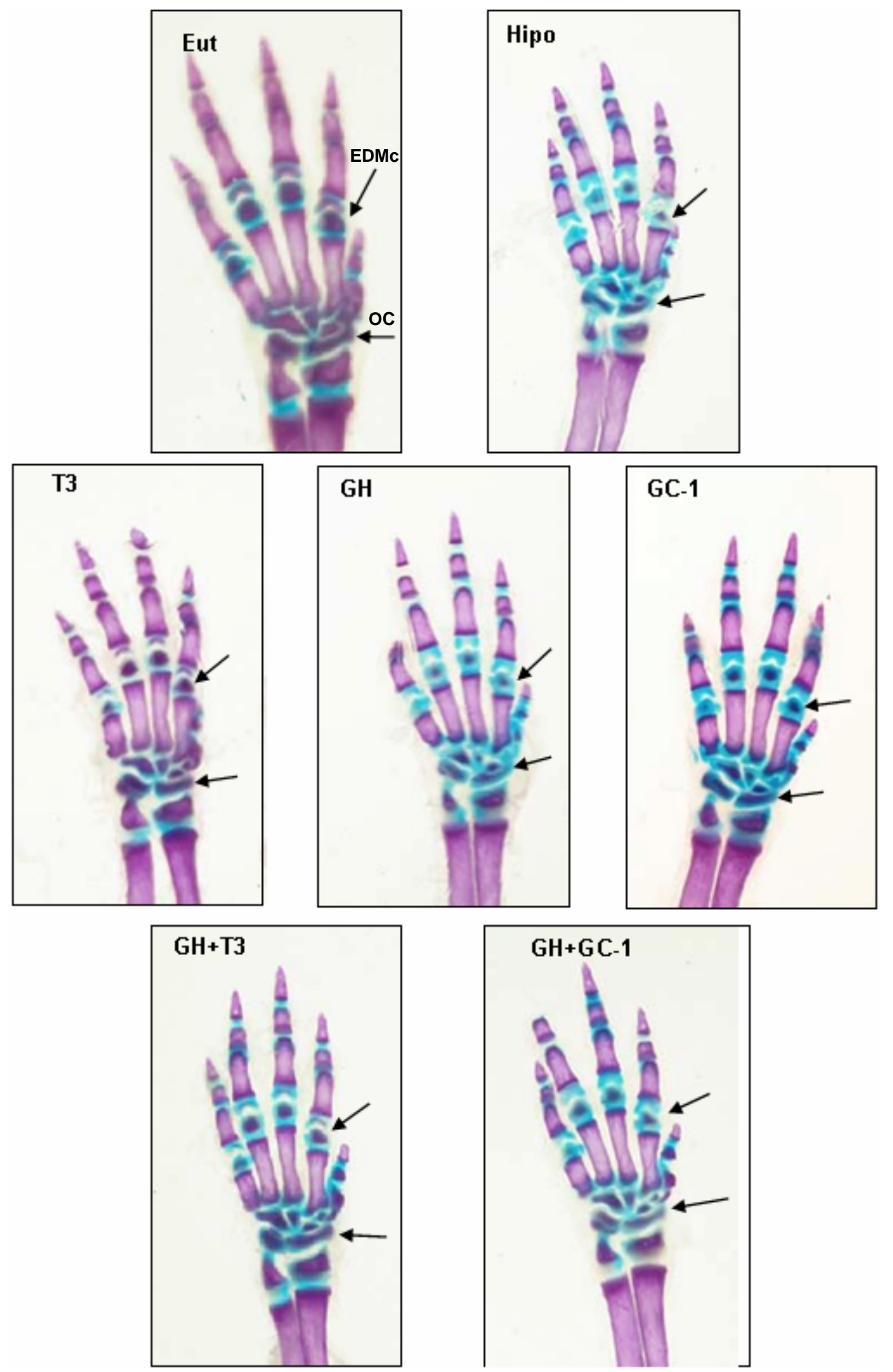

Figura 22: Efeito do tratamento com T3, GC-1 e/ou GH na ossificação endocondral da pata anterior esquerda (vista dorsal) de ratos neonatos hipotireoideos. As setas indicam os centros de ossificação, sendo que as setas superiores indicam as epífises distais dos metacarpos (EDMc) e as inferiores, os ossos do carpo (OC). Os esqueletos foram corados com vermelho de alizarina e azul de alcian. 
As Fig. 23 e 24 mostram o efeito da administração de GH sozinho ou combinado com T3 ou GC-1 na ossificação intramembranosa do fontículo posterior da calota craniana de ratos neonatos hipotireoideos. Como ocorre na ossificação endocondral, a condição de hipotireoidismo causa um severo atraso na ossificação intramembranosa. O grupo Hipo apresentou área do fontículo posterior 5,6 vezes maior do que a do grupo Eut $(\mathrm{p}<0,001)$. Esse atraso foi parcialmente revertido pelo tratamento com T3. A área do fontículo posterior foi 54\% menor nos animais tratados com T3 em relação ao grupo Hipo. O tratamento com GC-1 também apresentou efeito positivo sobre a ossificação intramembranosa, porém esse efeito foi mais modesto do que aquele do T3. Como mostrado na Fig. 23B, a área do fontículo posterior foi 22\% menor no grupo GC-1 em relação ao grupo Hipo.

Por outro lado, o tratamento com GH sozinho não reverteu o atraso na ossificação intramembranosa causado pelo hipotireoidismo e, ao contrário disso, intensificou o referido atraso. O grupo GH apresentou valores da área da fontículo posterior maiores do que o do grupo Hipo $(\mathrm{p}<0,05)$. Nota-se, ainda, que a associação do GH com o T3 ou GC-1 (GH+T3 e GH+GC-1) parece ter bloqueado o efeito desses dois ligantes na ossificação intramembranosa, uma vez que os animais tratados com GH+T3 e GH+GC-1 apresentaram uma maior área de fontanela do que aquelas dos grupos T3 (2,6 vezes, p<0,001) e GC-1 (1,5 vezes, $\mathrm{p}<0,01)$, respectivamente.
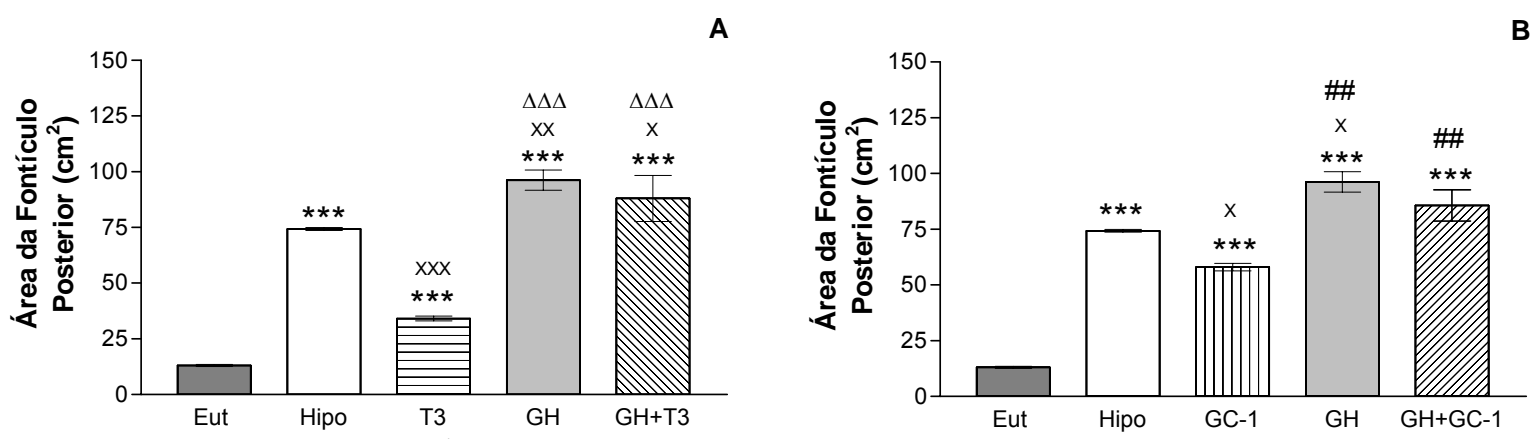

Figura 23: Efeito do tratamento com T3, GC-1 e/ou GH na ossificação intramembranosa da fontículo posterior de ratos neonatos hipotireoideos. Os animais receberam diariamente injeções de GH sozinho ou em combinação com T3 (A) ou com GC-1 (B).Todos os valores são expressos em média \pm EPM ( $n=3-4$ por grupo). $P<0,001$ (ANOVA). ${ }^{* *} p<0,001$ versus Eut, $x p<0,05, x x p<0,01$ e xxx $p<0,001$ versus Hipo, $\Delta \Delta \Delta p<0,001$ versus T3, \#\# $p<0,01$ versus GC-1, por Student-Newman-Keuls. 

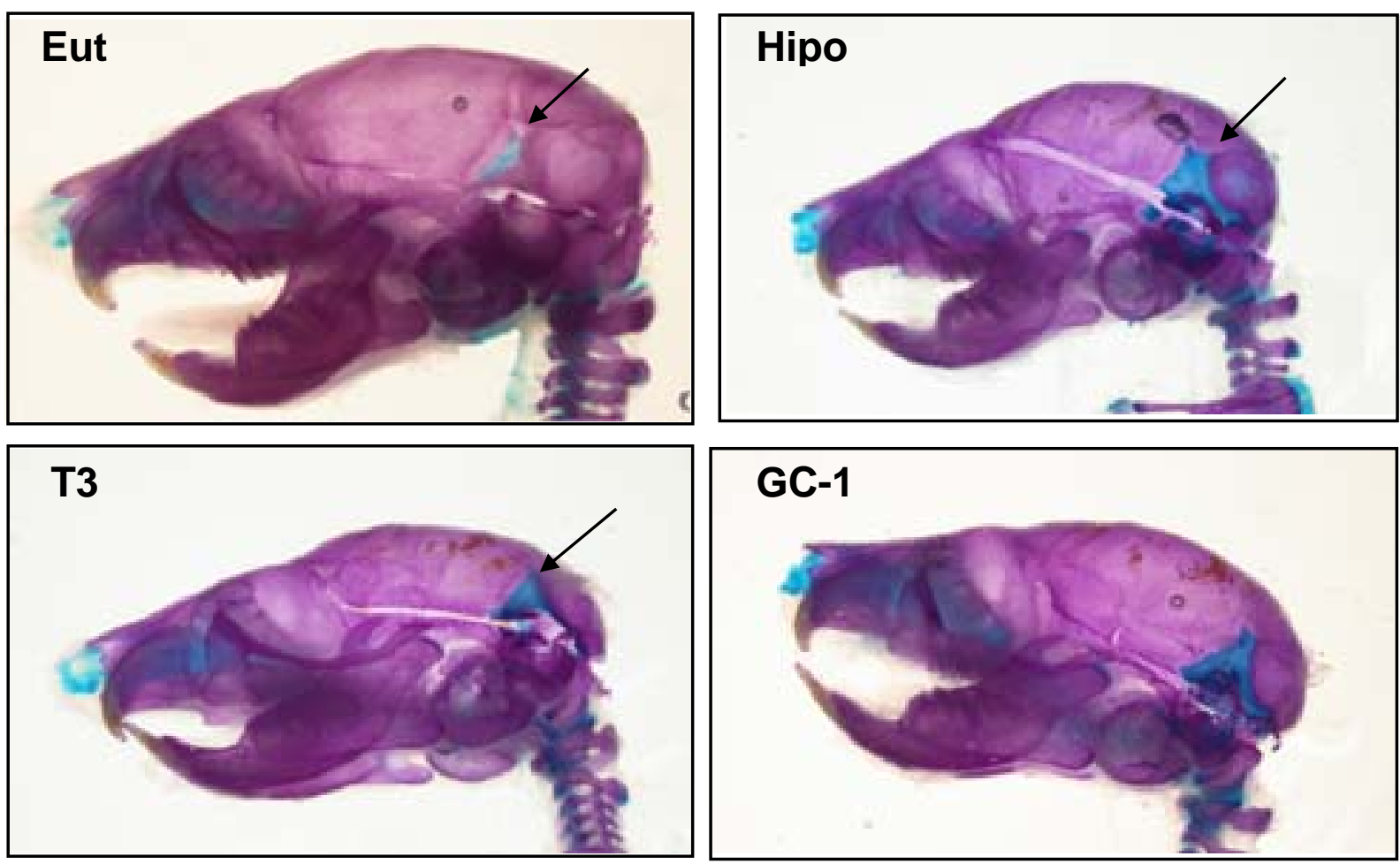

GC-1
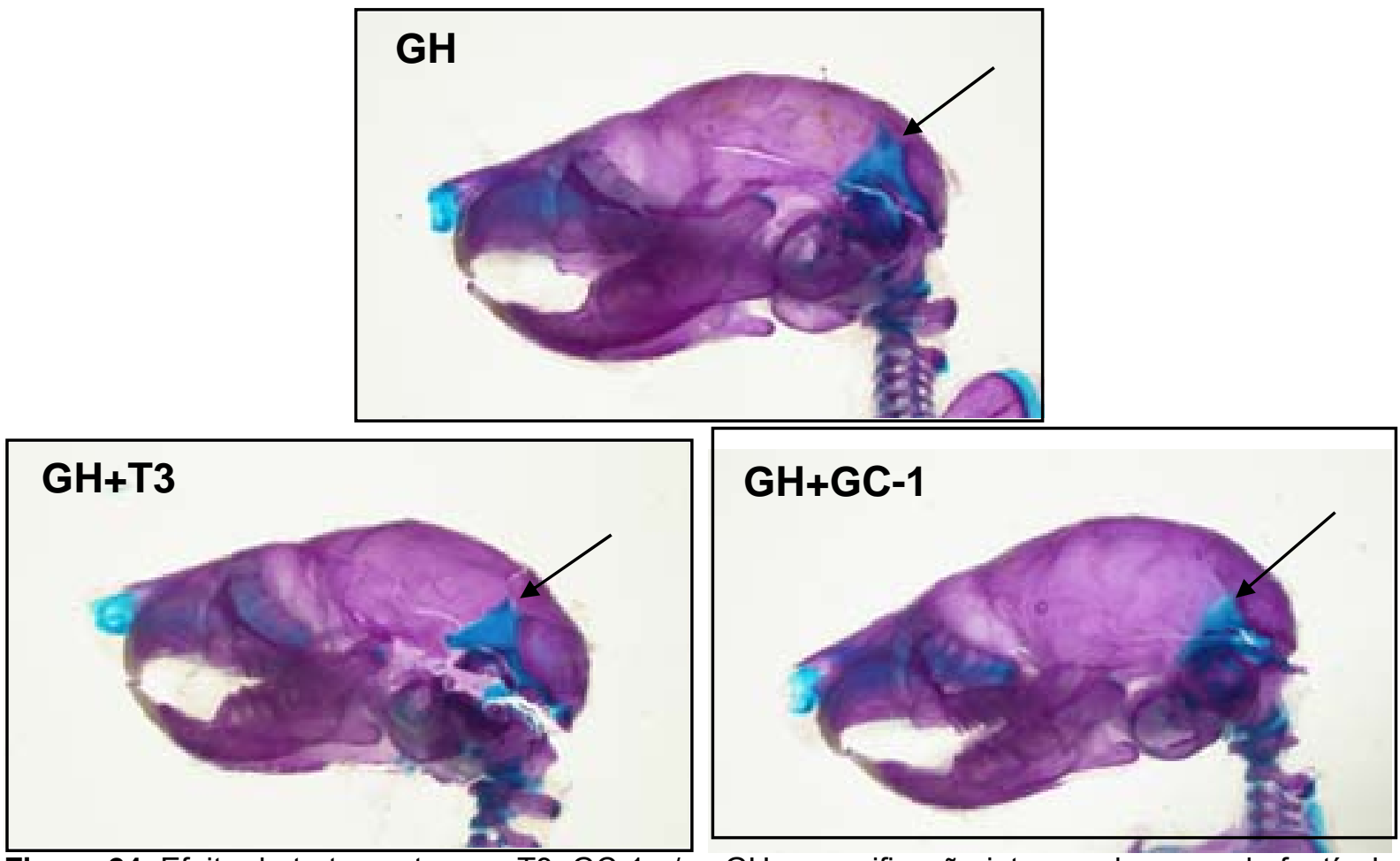

Figura 24: Efeito do tratamento com T3, GC-1 e/ou GH na ossificação intramembranosa da fontículo posterior (vista lateral esquerda) em ratas hipotireoideas. As setas indicam a fontanela marcada em azul. Os esqueletos foram corados com vermelho de alizarina e azul de alcian. 


\section{DISCUSSÃO}

O objetivo do presente estudo foi o de investigar o papel fisiológico do hormônio tireoideano e hormônio do crescimento no desenvolvimento ósseo, e mais especificamente, caracterizar o papel do TR $\beta$ na mediação do efeito do hormônio tireoideano nesse processo, utilizando o análogo do T3 seletivo pelo TR $\beta$, o GC-1, como ferramenta farmacológica. Resultados anteriores do nosso grupo mostraram que o tratamento de ratas jovens hipotireoideas com GC-1 reverteu alguns dos efeitos do hipotireoidismo, ao mesmo tempo em que não foi capaz de elevar os níveis séricos e protéico de IGF-I na lâmina epifisial (Freitas et al., 2005), sugerindo que o hormônio tireoideano tem efeitos no desenvolvimento esquelético que são independentes do eixo GH/IGF-I e mediados pelo TR $\beta$. No entanto, o GC-1 não foi capaz de promover uma série de efeitos característicos do T3, como por exemplo, induzir a organização das colunas de condrócitos proliferativos (Freitas et al., 2005) o que pode ter ocorrido em função da deficiência secundária do eixo GH/IGF-I, que acompanha o hipotireoidismo, ou pode refletir ações do hormônio tireoideano mediadas pelo TR $\alpha$. Com o objetivo de melhor investigarmos essas hipóteses, avaliamos o desenvolvimento esquelético de ratas jovens hipotireoideas tratadas com T3, GC-1, GH, GH+T3 ou GH+GC-1.

Como esperado, os níveis séricos de T4 estavam significativamente reduzidos ( 21 vezes versus Eut) em todos os animais submetidos ao tratamento com drogas inibidoras da função tireoideana (metimazol e perclorato de sódio) (Fig. 5), e aumentados nos animais tratados com T3 ( 6 vezes versus Eut). É digno de nota que o tratamento com GC-1 não alterou os níveis séricos de T3 e T4, mas que o tratamento com GH elevou os níveis séricos de T3 em 80\% em relação aos animais Hipo. Assim sendo, é possível que alguns efeitos do GH observados no presente estudo tenham sido mediados pelo próprio T3. O aumento do T3 sérico induzido pelo GH, provavelmente, se deve a um provável efeito do GH sobre as selenodesiodases das iodotironinas, uma vez que alguns estudos têm demonstrado que o GH estimula a conversão de T4 a T3. Geelhoed-Duijvestijn et al. (1992) estudaram o efeito da administração de GH nos níveis séricos e na produção tecidual de T3 em ratos tireoidectomizados com infusão contínua de T4 e GH. Nesse estudo, foi observado aumento nos níveis séricos de T3, bem como nos níveis teciduais em alguns órgãos que apresentam expressão das selenodesiodases das iodotironinas, como o fígado, rim e hipófise, indicando 
que o GH atua no metabolismo do hormônio tireoideano por estimular a atividade das desiodades (Geelhoed-Duijvestijn et al., 1992). Jorgensen et al. (1994) demonstraram que a administração de diferentes doses de GH em pacientes adultos com deficiência do hormônio do crescimento (GHD) aumentou os níveis séricos de T3 e reduziu os níveis de T3 reverso (T3r). Esses estudos indicam que o controle da conversão do T4 a T3 pode ser outro meio através do qual o GH interage com o hormônio tireoideano para regular o desenvolvimento e função de uma série de tecidos, incluindo o tecido ósseo. Considerando-se que as desiodases são expressas na lâmina epifisial, nos osteoblastos e nos osteoclastos (Miura et al., 2002; Gouveia et al., 2000), estudos futuros serão importantes para a investigação da interação do GH e hormônio tireoideano na regulação da expressão e atividade das desiodases no tecido ósseo.

Observamos, também, que os níveis séricos de IGF-I estavam (i) significativamente reduzidos nos animais Hipo, (ii) que o GH e T3 igualmente elevaram os níveis séricos de IGF-I, e (iii) que a associação do GH com o T3 (GH+T3) elevou o IGF-I ao nível dos animais Eut e significativamente além do T3 e GH sozinhos. Além disso, confirmamos que o GC-1 não teve efeito sobre os níveis séricos de IGF-I (Fig. 5).

De acordo com estudos anteriores (Freitas et al., 2005), o hipotireoidismo limitou significativamente o ganho de peso corporal (Fig. 6). Dos três ligantes, quando administrados sozinhos, o T3 foi o que promoveu maior ganho de peso, seguido pelo GH e GC-1 (T3>GH>GC-1). Por outro lado, a associação do GH com o T3 foi o único regime de tratamento a restabelecer completamente o ganho de peso corporal. A associação do GH com o GC-1 (GH+GC-1), por sua vez, resultou em um ganho de peso significativamente maior do que o observado no grupo tratado apenas com GH. Esses efeitos no peso corporal são parcialmente explicados pelo efeito desses tratamentos sobre o crescimento corporal. Vimos que o crescimento corporal longitudinal foi completamente bloqueado pela deficiência de hormônio tireoideano e que os animais tratados com T3 sozinho cresceram $20 \%$ menos que os animais Eut, mas quatro vezes mais do que os animais tratados com GH sozinho. Por outro lado, o tratamento com GH+T3 restabeleceu completamente o crescimento corporal. Já o GC1 teve um efeito bastante modesto sobre esse parâmetro, promovendo um crescimento 50\% menor do que aquele induzido pelo GH sozinho.

O fato de que o GH sozinho promoveu ganho de peso e crescimento corporal nos animais hipotireoideos mostra que o $\mathrm{GH}$, independentemente do $\mathrm{T} 3$, promove crescimento 
longitudinal ósseo. Isso está de acordo com estudos que mostram que o GH é capaz de promover o crescimento corporal de ratos hipofisectomizados, que também são deficientes de hormônio tireoideano (Nanto-Salonen et al., 1993; Hunziker et al., 1994; Chen et al., 1997). Além disso, Kindblom et al. (2001) demostraram que o GH é capaz de induzir o crescimento corporal em animais com deleção do TR $\alpha 1$ e TR $\beta$ (TR $\alpha 1-/-\beta-/-)$, que são deficientes do GH. Por outro lado, o menor efeito do GH versus T3 no crescimento e o fato do GH+T3 ser o único tratamento a restabelecer completamente o crescimento longitudinal indicam que o GH e T3 atuam em conjunto nesse processo. A observação de que o GC-1 promove um pequeno efeito positivo sobre o crescimento sugere que algumas ações do T3 no crescimento corporal são mediadas pelo TR $\beta$.

A análise da morfologia da lâmina epifisial (LE) mostrou que, como era de se esperar, os animais hipotireoideos apresentaram redução da espessura da LE e das zonas proliferativa (ZP) e hipertrófica $(\mathrm{ZH})$, além da redução do número de condrócitos proliferativos e hipertróficos e desorganização da ZP (Fig. 13-16). O tratamento com T3 reverteu quase que completamente as alterações na LE decorrentes do hipotireoidismo, enquanto que o tratamento com GC-1 praticamente não promoveu alterações morfológicas. De acordo com observações anteriores do nosso grupo (Freitas et al., 2005), vimos que, diferentemente do T3, o GC-1 não foi capaz de organizar as colunas de condrócitos proliferativos. Do mesmo modo, o GH sozinho ou em associação com o GC-1 (GH+GC-1) não foi capaz de promover a organização da ZP (Fig.16), apesar de aumentar significantemente a sua espessura (Fig. 13). De fato, Lewinson et al. (1989) mostraram que o tratamento de ratas hipotireoideas com GH não promoveu organização da lâmina epifisial. Considerando a seletividade do GC-1 ao TRß1 e os efeitos do GH, nossos resultados sugerem que a organização da lâmina epifisial é um efeito primariamente do hormônio tireoideano mediado pela $\mathrm{TR} \alpha$, e independente do eixo GH/IGF-I.

Um outro achado bastante interessante foi o fato do tratamento com GH aumentar as espessuras da LE e das zonas de reserva, proliferativa e hipertrófica além daquelas dos animais dos grupos Eut e T3, e que o tratamento T3 limitou esse efeito do GH, permitindo que essas espessuras igualassem-se àquelas do grupo Eut (Fig. 13). Esses resultados estão de acordo com achados que demonstram que a injeção de GH em animais hipofisectomizados é capaz de pelo menos restaurar a espessura da lâmina epifisial (Chen et al., 1997; Reinecke et 
al., 2000). Além disso, nossos achados mostram a importância da interação do GH com o T3 para a manutenção da morfologia normal da lâmina epifisial.

Um resultado importante deste estudo é que o tratamento com GH promoveu um aumento significativo do número de condrócitos hipertróficos, além dos valores apresentados pelos grupos Eut e T3 (48\% e 62\%, respectivamente). Esse resultado diverge daqueles de um estudo de Lewinson et al. (1989), que mostraram que o tratamento de ratos hipotiroideos com GH não promove a diferenciação de condrócitos hipertróficos na lâmina epifisial. Essa diferença nos resultados pode ser devido ao fato de que no estudo citado, ao contrário do nosso estudo, a dose de GH utilizada não elevou os níveis séricos de IGF-I aos valores do grupo eutireoideo. Assim sendo, os nossos resultados sugerem fortemente que o eixo GH/IGF-I, e não somente o hormônio tireoideano, apresenta efeitos importantes na hipertrofia dos condrócitos da lâmina epifisial. Esse achado é bastante importante, pois derruba a teoria postulada por Lewinson et al (1989) de que a diferenciação dos condrócitos proliferativos em hipertróficos é um efeito primariamente do T3.

Como esperado, vimos que o hipotireoidismo induziu um atraso generalizado na ossificação endocondral e intramembranosa, que esse atraso foi quase que completamente revertido pelo T3 e que o GC-1 apenas parcialmente reverteu o atraso na ossificação do esqueleto. Observamos, ainda, que o sozinho GH não apresentou efeitos no processo de ossificação endocondral. O tratamento de ratos neonatos hipotireoideos com GH não foi capaz de aumentar o tamanho dos centros secundários de ossificação, além de não ter alterado o efeito do T3 nesse processo. Nossos dados estão de acordo com Kindblom et al. (2001), que mostraram que o tratamento com GH não apresenta efeitos na ossificação de animais com deleção do TR $\alpha 1$ e $\operatorname{TR} \beta\left(\operatorname{TR} \alpha 1^{-/} \operatorname{TR} \beta^{-/}\right)$, que por sua vez, apresentam retardo no crescimento e na ossificação do esqueleto, e diminuição dos níveis de GH e IGF-I (Göthe et al., 1999). Considerando-se que o GH sozinho não apresentou efeitos na ossificação, que o GC-1 parcialmente reverteu o atraso na ossificação do esqueleto e a seletividade do TR $\beta$ a esse análogo, o presente estudo sugere que os efeitos do T3 na ossificação são primariamente independentes do eixo GH/IGF-I, e mediados tanto pelo TR $\alpha 1$ quanto pelo TR $\beta 1$. Entretanto, é digno de nota que a associação do GH com o GC-1 teve um efeito positivo sobre a ossificação endocondral, uma vez que a área do centro de ossificação secundária no fêmur dos animais tratados com GH+GC-1 foi maior do que aquela dos animais tratados apenas com GC-1 ( 42\%; Fig. 19 e 20). Esse achado sugere que o GH depende da ação do hormônio 
tireoideano para induzir a ossificação endocondral. Assim sendo, um efeito aditivo entre o hormônio tireoideano e o eixo GH/IGF-I no processo de ossificação deve ser considerado. Uma forte evidência de que o eixo GH/IGF-I participa do processo de ossificação do esqueleto é o fato de que animais com deleção dos receptores de GH e IGF-I também apresentam atraso nesse processo (Liu et al, 1993; Sjogren et al, 2000). Com relação ao atraso na ossificação intramembranosa do fontículo posterior decorrente do hipotireoidismo, foi interessante observar que o tratamento com GH sozinho o intensificou e que a associação do GH com o GC-1 ou T3 bloqueou o efeito positivo de ambos os ligantes na reversão desse atraso (Fig. 23 e 24). Sabendo-se que o GH é importante para o crescimento crânio-facial (Van Erum et al., 1997), é possível que esse hormônio limite o processo de ossificação intramembranosa induzido pelo hormônio tireoideano justamente para permitir que o crescimento ocorra. Assim sendo, os nossos achados sugerem que haja um balanço entre a ação positiva do T3 e negativa do GH no processo de ossificação intramembranosa, pelo menos nos ossos do crânio, para permitir o desenvolvimento esquelético normal.

De acordo com observações anteriores (Freitas et al., 2005), vimos que a deficiência de hormônio tireoideano impediu o ganho de massa óssea em todos os sítios do esqueleto avaliados. Além disso, vimos que o tratamento com T3 promoveu ganho de BMD 2,1-2,8 vezes maior do que o observado nos animais hipotireoideos, também em todas as regiões estudadas. Ainda confirmando observações anteriores, o GC-1 positivamente afetou o ganho de BMD (38 a 65\% versus Hipo) nas vértebras lombares, fêmur (fêmur total e terços médio e distal) e tíbia (terços proximal e médio), entretanto, esse efeito foi significativamente menor do que o do T3 (32 a 55 \%). Considerando-se que o hipotireoidismo é acompanhado por uma diminuição da atividade do eixo GH/IGF-I, levantamos a hipótese de que o prejuízo no ganho de BMD fosse resultado da deficiência de GH e/ou IGF-I. É bem conhecido que o GH aumenta a atividade osteoblástica (Kassem et al., 1993; Morel et al., 1993) e que a deficiência de GH/IGF-I está associada com baixa densidade óssea. Chen et al. (1997) mostraram que o GH é capaz de aumentar a massa óssea, com aumento da taxa de deposição mineral e da taxa de formação óssea em ratas hipofisectomizadas. É digno de nota, entretanto, que, no presente estudo, o GH, promoveu efeitos bastante brandos na aquisição de massa óssea, apesar de ter elevado as concentrações plasmáticas de IGF-I ao nível dos animais eutireoideos. Vimos que o GH sozinho melhorou em apenas 1,3 a 2,1 vezes o ganho de BMD, em comparação ao grupo Hipo, nas vértebras lombares, no fêmur (fêmur total e terços proximal e médio) e na tíbia (terço médio). Por outro lado, a associação do GH com o T3 (GH+T3) melhorou o ganho 
de BMD em relação ao T3 sozinho apenas nas vértebras lombares (1,2 vezes), enquanto que o GH associado ao GC-1 (GH+GC-1) melhorou o ganho de BMD em relação ao GC-1 sozinho no terço médio do fêmur e terço distal da tíbia (1,2 vezes). Esses achados sugerem que o GH e/ou IGF-I dependem de uma condição eutireoidea sistêmica e/ou tecidual para promover ganhos de massa óssea mais significativos. Lembrando-se que o GC-1 não eleva os níveis séricos de IGF-I e que esse análogo induziu de forma branda, mas significativa a aquisição de massa óssea, pode-se considerar que o T3 possivelmente tem efeitos no ganho de massa óssea que são independentes do eixo GH/IGF-I e mediados pelo TR $\beta$. Por outro lado, considerandose, ainda, que o T3 promoveu ganho de BMD 52 a 74\% maior do que o GC-1, os achados deste estudo sugerem que o TR $\alpha$ provavelmente tem o principal papel de mediar as ações anabólicas do T3 na massa óssea. Assim sendo, podemos concluir que o T3 age na massa óssea de maneira dependente e independente do eixo GH/IGF-I e que os seus efeitos diretos são mediados pelo TR $\beta$ e, principalmente, pelo TR $\alpha 1$.

Sabe-se que a resistência óssea correlaciona-se positivamente com massa óssea (Geusens et al., 1990). Contudo, aumento da taxa de fraturas ósseas não pode ser explicado somente pelas variações da massa óssea. A habilidade de um osso de resistir a um estresse mecânico depende da quantidade de osso (massa óssea), sua arquitetura (número, separação e conectividade das trabéculas), turnover ósseo, e também das propriedades da matriz óssea (porção orgânica e mineral), dentre outros fatores (Friedman, 2006). Assim, a resistência óssea depende da massa óssea e da qualidade óssea, que pode ser definida como todos os atributos de um osso, com exceção da massa óssea, que podem contribuir para a sua resistência ou fragilidade (Compston, 2006). Dessa forma, a realização de testes biomecânicos permite uma avaliação mais precisa do impacto de determinados fatores sobre o esqueleto. Com relação a parâmetros biomecânicos de um osso, sabe-se que a resistência óssea depende de fatores como a rigidez, resiliência e tenacidade do tecido ósseo, sendo esses parâmetros também determinantes da qualidade óssea (Friedman, 2006). No presente estudo, mostramos que o hormônio tireoideano altera de maneira importante a biomecânica óssea tibial, uma vez que os animais hipotireoideos apresentaram todos os parâmetros biomecânicos analisados (carga máxima, rigidez, resiliência e tenacidade) significativamente menores do que os animais eutireoideos.

Com relação à carga máxima, que reflete a resistência óssea, vimos que o T3, GC-1 e GH promoveram aumentos significativos desse parâmetro em relação aos animais 
hipotireoideos (Fig. 12A e 12B). Vimos que o GC-1 e GH igualmente afetaram esse parâmetro, e que o efeito do GH foi significativamente menor do que o do T3. Esses resultados estão de acordo com os efeitos de todos esses ligantes sobre a massa óssea tibial (Fig. 11). Entretanto, é digno de nota que a associação do GH com o T3 (GH+T3) resultou em uma carga máxima, mas não em uma massa óssea tibial, significativamente maior do que aquela apresentada pelo grupo T3. Esses achados mostram que o T3 e GH são determinantes da resistência óssea e que esses ligantes regulam esse parâmetro não só através dos seus efeitos sobre a massa óssea, mas também regulando outros fatores que refletem em uma maior qualidade óssea.

É notável que o GC-1 e o GH não afetaram a rigidez óssea em relação aos animais hipotireoideos, enquanto que o T3 significativamente elevou esse parâmetro (49\% versus Hipo) (Fig. 12C e 12D). Considerando-se que a rigidez óssea é determinada pelo conteúdo mineral da matriz óssea, esses achados sugerem que o T3, mas não o GH e GC-1, apresentou efeito sobre a mineralização do esqueleto nos animais hipotireoideos. Considerando-se, ainda, a seletividade do TR $\beta$ pelo GC-1, o efeito do T3 sobre a rigidez óssea é provavelmente mediado pelo TR $\alpha$.

Com relação à resiliência, que reflete a capacidade de um osso de sofrer deformação elástica, observa-se que o T3, GC-1 e GH promoveram efeitos positivos e bastante similares (Fig. 12E e 12F). Entretanto, observa-se que a associação do GH com o T3 (GH+T3) resultou em uma resiliência significativamente maior do que aquela induzida por ambos os ligantes quando administrados sozinhos. A tenacidade, que é a quantidade de energia necessária para fraturar um osso, não foi afetada significativamente pelo T3, GC-1 ou GH, apesar de uma clara tendência a aumento nos animais tratados com esses ligantes, em relação ao grupo Hipo. Nota-se, entretanto, que a associação do GH com o T3 (GH+T3) ou com o GC-1 (GH+GC-1) resultou em uma tenacidade significativamente maior do que aquela apresentada pelo grupo Hipo. Esses achados fortalecem a idéia de que tanto o T3 quanto o GH são determinantes de uma melhor qualidade óssea. Vale ser dito que a resiliência e tenacidade são determinadas principalmente pelo componente orgânico da matriz extracelular (Friedman, 2006). Considerando-se que o efeito do T3 e GC-1 foi bastante similar sobre esses parâmetros, é bastante provável que o TR $\beta$ seja a isoforma responsável por mediar os efeitos do T3 sobre a matriz orgânica que, por sua vez, refletem no aumento da resiliência e tenacidade. 
Praticamente, não há estudos sobre os efeitos do hormônio tireoideano e do hormônio do crescimento na resistência óssea. Lange et al. (2004) mostraram que ratos com deficiência de GH (animais Dw-4) apresentam diminuição da carga máxima, rigidez e tenacidade, seguido da redução do número e desorganização das fibras de colágeno. Os nossos achados sugerem que o tratamento com GC-1 ou GH aumenta a resistência óssea em animais Hipo por aumentar a massa óssea e tornar o osso mais capaz de sofrer uma deformação elástica (resiliência), e não mais rígido; enquanto que o T3 aumenta a resistência óssea por aumentar a massa, resiliência e a rigidez ósseas. 


\section{CONCLUSÃO}

Os resultados do presente estudo mostram que:

- Considerando-se que o tratamento com T3 quase que completamente restabelece o crescimento corporal longitudinal no hipotireoidismo; que o $\mathrm{GH}$, independemente do T3, tem um efeito apenas modesto; e que o $\mathrm{GH}+\mathrm{T} 3$ restabelece por completo o crescimento, pode-se concluir que o crescimento corporal longitudinal depende da ação conjunta do GH e T3;

- Considerando-se o efeito positivo do T3 e GC-1 sobre o crescimento corporal longitudinal, o efeito do hormônio tireoideano sobre esse processo é provavelmente mediado pelo TR $\beta$ e $\mathrm{TR} \alpha$

- Considerando-se que, ao contrário do T3, o GC-1 e GH não foram capazes de organizar os condrócitos da zona proliferativa da lâmina epifisária em colunas, o TR $\alpha$ é provavelmente a isoforma de TR que medeia a ação do T3 nesse processo;

- Considerando-se o efeito positivo do T3 e GH, quando administrados sozinhos, sobre o número de condrócitos hipertróficos, pode-se considerar que tanto o eixo GH/IGF-I quanto o hormônio tireoideano são importantes indutores da diferenciação dos condrócitos proliferativos em hipertróficos.

- Considerando-se o efeito positivo do T3 e GC-1 sobre a ossificação endocondral, e que o GH sozinho não induziu esse processo, podemos concluir que o T3 atua sobre a ossificação endocondral primariamente independentemente do eixo GH/IGF-I, e via TR $\alpha 1$ e TR $\beta 1$;

- Considerando-se que camundongos com deleção dos receptores de GH e IGF-I apresentam atraso na ossificação do esqueleto, que o GH sozinho não induz a ossificação endocondral, mas que o GH associado ao GC-1 induziu a ossificação, pode-se concluir que o GH depende da ação do hormônio tireoideano para induzir a ossificação endocondral. Assim sendo, um efeito aditivo entre o hormônio tireoideano e o eixo GH/IGF-I no processo de ossificação deve ser considerado; 
- Considerando-se que a ossificação intramembranosa do fontículo posterior é induzida pelo T3 e GC-1 e inibida pelo GH, o presente estudo sugere que o TR $\alpha$ e TR $\beta$ medeiam a ação do T3 nesse processo e que um balanço entre a ação do T3 e GH na ossificação intramembranosa seja essencial para permitir o desenvolvimento esquelético normal dos ossos do crânio;

- Considerando-se que o GH sozinho teve um efeito apenas modesto sobre o ganho de massa óssea e que, a associação do GH com o T3 ou com o GC-1 praticamente não alterou o efeito desses dois análogos sobre o ganho de massa óssea, podemos concluir que o T3 age sobre a aquisição de massa óssea prioritariamente de maneira independente do eixo GH/IGF-I;

- Considerando-se que o T3 e GC-1 promoveram ganho de BMD, mas que o efeito do GC-1 foi apenas modesto, os achados deste estudo sugerem que o T3 age na massa óssea via TR $\beta$ e, principalmente, via TR $\alpha 1$;

- Os nossos achados sugerem que o T3 e GH são determinantes da resistência óssea e que esses ligantes regulam esse parâmetro não só através dos seus efeitos sobre a massa óssea, mas também regulando outros fatores que contribuem para uma melhor qualidade óssea;

- Considerando-se a seletividade do TR $\beta$ pelo GC-1 e que, ao contrário do T3, o GC-1 não promoveu aumento da rigidez óssea, o efeito do positivo do T3 sobre esse parâmetro é provavelmente mediado pelo TR $\alpha$;

- Considerando-se que o efeito do T3 e GC-1 foram bastante similares sobre a resiliência e tenacidade ósseas e que esses parâmetros biomecânicos são determinados especialmente pela matriz orgânica, é bastante provável que o TR $\beta$ seja a isoforma que predominantemente medeia os efeitos do T3 sobre a matriz orgânica que determinam uma maior resistência óssea;

- Os nossos achados sugerem que os tratamentos com GC-1 ou GH aumentam a resistência óssea em animais Hipo por aumentar a massa óssea e tornar o osso mais resiliente (ou seja, mais capaz de sofrer uma deformação elástica), e não mais rígido; enquanto que o T3 aumenta a resistência óssea por aumentar a massa, resiliência e a rigidez ósseas. 


\section{REFERÊNCIAS BIBLIOGRÁFICAS*}

Abu EO, Bord S, Horner A, Chatterjee VK, Compston JE. The expression of thyroid hormone receptors in human bone. Bone. 1997; 21:137-42.

Allain TJ, McGregor AM. Thyroid hormones and bone. J Endocrinol. 1993; 139:9-18.

Allain TJ, Yen PM, Flanagan AM, McGregor AM. The isoform-specific expression of the triiodothyronine receptor in osteoblasts and osteoclasts. Eur J Clin Invest. 1996; 26:418-25.

Ballock RT, Reddi AH. Thyroxine is the serum factor that regulates morphogenesis of columnar cartilage from isolated chondrocytes in chemically defined medium. J Cell Biol. 1994; 126: 1311-8.

Ballock R, Mita BC, Zhou X, Chen DH, Mink LM. Expression of thyroid hormone receptor isoforms in rat growth plate cartilage in vivo. J Bone Miner Res. 1999; 14:1550-6.

Barnard R, Ng KW, Martin TJ, Waters MJ. Growth hormone (GH) receptors in clonal osteoblast-like cells mediate a mitogenic response to GH. Endocrinology. 1991; 128:1459-64.

Baron R. General Principles of Bone Biology. In: Favus MJ, editor. Primer on the Metabolic Bone Diseases and Disorders of Mineral Metabolism. 5 ed. Washington: The American Society for Bone and Mineral Research; 2003. p. 1-8.

Bassett JH, Williams GR. The molecular actions of thyroid hormone in bone. Trends Endocrinol Metab. 2003; 14:356-64.

Basset JH, Harvey CB, Williams GR. Mechanisms of throid hormone receptor-specific nuclear and extra nuclear actions. Mol Cel Endocrinol. 2003; 213: 1-11.

Behringer RR, Lewin TM, Quaifer CJ, Palmiter RD, Brinster RL, D’Ercole AJ. Expression of insulin-like growth factor I stimulates normal somatic growth in growth hormone-deficient transgenic mice. Endocrinology. 1990; 127 (3):1033-40.

\footnotetext{
* De acordo com:

International Committee of Medical Journal Editors. Uniform requirements for manuscripts submitted to Biomedical Journal: sample references. Available from: http://www.icmje.org [2004 May 06].
} 
Bianco AC, Salvatore D, Gereben B, Berry MJ, Larsen PR. Biochemistry, cellular and molecular biology, and physiological roles of the iodothyronine selenodeiodinases. Endocr Rev, 2002; 23:38-89.

Bikle D, Majumdar S, Laib A, Powell-Braxton L, Beamer W, Nauman E, Leary C, Halloran B. The skeletal structure of insulin-like growth factor I-deficient mice. J Bone Miner Res. 2001; 16:2320-9.

Burstein S, Grumbach MM, Kaplan SL, Li CH. Immunoreactivity and receptor binding of mixed recombinants of human growth hormone and chorionic somatomammotropin. Proc Natl Acad Sci USA. 1978; 75:5391-4.

Campbell PG, Andress DL. Insulin-like growth factor (IGF)-binding protein-5-(201-218) region regulates hydroxyapatite and IGF-I binding. Am J Physiol. 1997; 273:E1005-13.

Carlsson B, Billig H, Rymo L, Isaksson OG. Expression of the growth hormone-binding protein messenger RNA in the liver and extrahepatic tissues in the rat: co-expression with the growth hormone receptor. Mol Cell Endocrinol. 1990; 73:R1-6.

Chen MM, Yeh JK, Aloia JF. Histologic evidence: growth hormone completely prevents reduction in cortical bone gain and partially prevents cancellous osteopenia in the tibia of hypophysectomized rats. Anat Rec. 1997; 249:163-72.

Chiellini G, Apriletti JW, Yoshihara HA, Baxter JD, Ribeiro RC, Scanlan TS. A high-affinity subtype-selective agonist ligand for the thyroid hormone receptor. Chem Biol. 1998; 5:299306.

Columbano A, Pibiri M, Deidda M, Cossu C, Scanlan TS, Chiellini G, Muntoni S, LeddaColumbano GM. The thyroid hormone receptor-beta agonist GC-1 induces cell proliferation in rat liver and pancreas. Endocrinology. 2006; 147:3211-8.

Comoston J. Bone Quality: What is it and How is it Measured?. Arq Bras Endocrinol Metab. 2006: 50 (4):579-85.

Cook CB, Kakucska I, Lechan RM, Koenig RJ. Expression of thyroid hormone receptor beta 2 in rat hypothalamus. Endocrinology. 1992; 130:1077-9.

Daughaday WH, Reeder C. Synchronous activation of DNA synthesis in hypophysectomized rat cartilage by growth hormone. J Lab Clin Med. 1966; 68:357-68. 
Daughaday WH, Hall K, Raben MS, Salmon WD Jr, van den Brande JL, van Wyk JJ. Somatomedin: proposed designation for sulphation factor. Nature. 1972; 235:107.

D'Ercole A, Applewhite G, Underwood L. Evidence that somatomedin is synthesized by multiple tissues in the fetus. Dev Biol. 1980; 75:315-328.

Eckey M, Moehren U, Baniahmad A. Gene silencing by the thyroid hormone receptor. Mol Cell Endocrinol. 2003; 213:13-22.

Edens A, Talamantes F. Alternative processing of growth hormone receptor transcripts. Endocr Rev. 1998; 19:559-82.

Engler D, Burger AG. The deiodination of the iodothyronines and of their derivatives in man. Endocr Rev. 1984; 5:151-84.

Evans R. The Steroid and Thyroid Hormone Receptor Superfamily. Science. 1988; 240:889895.

Firth SM, Baxter RC. Cellular actions of the insulin-like growth factor binding proteins. Endocr Rev. 2002; 23:824-54.

Flamant F, Poguet AL, Plateroti M, Chassande O, Gauthier K, Streichenberger N, Mansouria A, Samarut J. Congenital hypothyroid Pax8(-/-) mutant mice can be rescued by inactivating the TRalpha gene. Mol Endocrinol. 2002; 16(1):24-32.

Forrest D, Sjoberg M, Vennstrom B. Contrasting developmental and tissue-specific expression of alpha and beta thyroid hormone receptor genes. Embo J. 1990; 9:1519-28.

Forrest D, Hanebuth E, Smeyne RJ, Everds N, Stewart CL, Wehner JM, et al. Recessive resistance to thyroid hormone in mice lacking thyroid hormone receptor beta: evidence for tissue-specific modulation of receptor function. Embo J. 1996; 15:3006-15.

Fox JN, Kimura S, Plato CC. Bilateral asymmetry in bone weight at various skeletal sites of the rat. Anat Rec. 1995; 241:284-287.

Fraichard A, Chassande O, Plateroti M, Roux JJP, Trouillas J, Dehay C, Legrand C, Rousset $\mathrm{B}$, Samarut J. The T3R alpha gene encoding a thyroid hormone receptor is essential for postnatal development and thyroid hormone production. Embo J. 1997; 16:4412-20. 
Franz-Odendall TA, Hall BK, Witten PE. Buried Alive: How osteoblasts become osteocytes. Developmental Dynamics. 2006; 235:176-90.

Freedman LP. Anatomy of the steroid receptor zinc finger region. Endocr Rev. 1992; 13:129145.

Freitas FR, Capelo LP, O'Shea PJ, Jorgetti V, Moriscot AS, Scanlan TS, Williams GR, Zorn TM, Gouveia $\mathrm{CH}$. The thyroid hormone receptor beta-specific agonist GC-1 selectively affects the bone development of hypothyroid rats. J Bone Miner Res. 2005; 20:294-304.

Friedman AW. Important determinants of bone strength: beyond bone mineral density. J Clin Rheumatol. 2005; 12:70-7.

Furlow JD, Yang HY, Hsu M, Lim W, Ermio DJ, Chiellini G, Scanlan TS. Induction of larval tissue resorption in Xenopus laevis tadpoles by the thyroid hormone receptor agonist GC-1. J Biol Chem. 2004. 279:26555-62.

Gauthier K, Chassande O, Plateroti M, Roux JP, Legrand C, Pain B, Rousset B, Weiss R, Trouillas J, Samarut J. Different functions for the thyroid hormone receptors TRalpha and TRbeta in the control of thyroid hormone production and post-natal development. Embo J. 1999; 18:623-31.

Gauthier K, Plateroti M, Harvey CB, Williams GR, Weiss RE, Refetoff S, Willott JF, Sundin V, Roux JP, Malaval L, Hara M, Samarut J, Chassande O. Genetic analysis reveals different functions for the products of the thyroid hormone receptor alpha locus. Mol Cell Biol. 2001; 21:4748-60.

Geelhoed-Duijvestijn PH, Roelfsema F, Schroder-van der Elst JP, van Doorn J, van der Heide D. Effect of administration of growth hormone on plasma and intracellular levels of thyroxine and tri-iodothyronine in thyroidectomized thyroxine-treated rats. J Endocrinol. 1992; 133:459.

Geusens P, Dequeker J, Nijs J, Bramm E. Effect of ovariectomy and prednisolone on bone mineral content in rats: evaluation by single photon absorptiometry and radiogrammetry. Calcif Tissue Int. 1990; 47:243-50.

Gevers EF, van der Eerden BC, Karperien M, Raap AK, Robinson IC, Wit JM. Localization and regulation of the growth hormone receptor and growth hormone-binding protein in the rat growth plate. J Bone Miner Res. 2002; 17:1408-19. 
Glass CK, Franco R, Weinberger C, Albert VR, Evans RM, Rosenfeld MG. A c-erb-A binding site in rat growth hormone gene mediates trans-activation by thyroid hormone. Nature. 1987; 329:738-41.

Glasscock GF, Nicoll CS. Hormonal control of growth in the infant rat: further evidence that neither thyrotropin nor thyroid hormones are transferred via milk to suckling pups. Endocrinology. 1983; 112:800-5.

Gloss B, Trost S, Bluhm W, Swanson E, Clark R, Winkfein R, Janzen K, Giles W, Chassande O, Samarut J, Dillmann W. Cardiac ion channel expression and contractile function in mice with deletion of thyroid hormone receptor alpha or beta. Endocrinology. 2001; 142:544-50.

Göthe S, Wang Z, Ng L, Kindblom JM, Barro AC, Ohlsson C, Vennström B, Forrest D. Mice devoid of all known thyroid hormone receptors are viable but exhibit disorders of the pituitary-thyroid axis, growth, and bone maturation. Genes Dev. 1999; 13:1329-41.

Gouveia CH, Christoffolete MA, Zaitune CR, Dora JM, Harney JW, Maia AL, Bianco AC. Type 2 iodothyronine selenodeiodinase is expressed throughout the mouse skeleton and in the MC3T3-E1 mouse osteoblastic cell line during differentiation. Endocrinology. 2005; 146(1):195-2000.

Green H, Morikawa M, Nixon T. A dual effector theory of growth-hormone action. Differentiation. 1985; 29:195-8.

Gruber R, Czerwenka K, Wolf F, Ho GM, Willheim M, Peterlik M. Expression of the vitamin $\mathrm{D}$ receptor, of estrogen and thyroid hormone receptor alpha- and beta-isoforms, and of the androgen receptor in cultures of native mouse bone marrow and of stromal/osteoblastic cells. Bone. 1999; 24:465-73.

Harvey CB, O'Shea PJ, Scott AJ, Robson H, Siebler T, Shalet SM, Samarut J, Chassande O, Williams GR. Molecular mechanisms of thyroid hormone effects on bone growth and function. Mol Genet Metab 75:17-30, 2002

Hill PA, Reynolds JJ, Meikle MC. Osteoblasts mediate insulin-like growth factor-I and -II stimulation of osteoclast formation and function. Endocrinology. 1995; 136:124-31.

Hoskins WE, Asling CW. Influence of growth hormone and thyroxine on endochondral osteogenesis in the mandibular condyle and proximal tibial epiphysis. J Dent Res. 1977; 56(5):509-17. 
Hodin RA, Lazar MA, Chin WW. Differential and tissue-specific regulation of the multiple rat c-erbA messenger RNA species by thyroid hormone. J Clin Invest. 1990; 85:101-5.

Hunziker EB, Wagner J, Zapf J. Differential effects of insulin-like growth factor I and growth hormone on developmental stages of rat growth plate chondrocytes in vivo. J Clin Invest. 1994; 93:1078-86.

Ishikawa Y, Genge BR, Wuthier RE, Wu LN. Thyroid hormone inhibits growth and stimulates terminal differentiation of epiphyseal growth plate chondrocytes. J Bone Miner Res. 1998; 13(9):1398-411.

Jorgensen JO, Moller J, Laursen T, Orskov H, Christiansen JS, Weeke J. Growth hormone administration stimulates energy expenditure and extrathyroidal conversion of thyroxine to triiodothyronine in a dose-dependent manner and suppresses circadian thyrotrophin levels: studies in GH-deficient adults. Clin Endocrinol (Oxf). 1994; 41:609-14.

Kavok NS, Krasilnikova OA, Babenko NA. 2001. Thyroxine signal transduction in liver cells involves phospholipase $\mathrm{C}$ and phospholise $\mathrm{D}$ activation, genomic independent action of thyroid hormone. BMC Cell Biol. 2001; 2: 5.

Kanatani M, Sugimoto T, Nishiyama K, Chihara K. Stimulatory effect of insulin-like growth factor binding protein-5 on mouse osteoclast formation and osteoclastic bone-resorbing activity. J Bone Miner Res. 2000; 15:902-10.

Kassem M, Mosekilde L, Eriksen EF. Effects of triiodothyronine on DNA synthesis and differentiation markers of normal human osteoblast-like cells in vitro. Biochem Mol Biol Int. 1993; 30:779-88.

Katz D, Lazar MA. Dominant negative activity of an endogenous thyroid hormone receptor variant (alpha 2) is due to competition for binding sites on target genes. J Biol Chem. 1993; 268:20904-10.

Kindblom JM, Gothe S, Forrest D, Tornell J, Vennstrom B, Ohlsson C. GH substitution reverses the growth phenotype but not the defective ossification in thyroid hormone receptor alpha 1-/-beta-/- mice. J Endocrinol. 2001; 171:15-22.

Koenig RJ, Brent GA, Warne RL, Larsen PR, Moore DD. Thyroid hormone receptor binds to a site in the rat growth hormone promoter required for induction by thyroid hormone. Proc Natl Acad Sci USA. 1987; 84:5670-4. 
Knothe Tate ML, Adamson JR, Tami AE, Bauer TW. The osteocyte. Int J Biochem Cell Biol. 2004; 36: 1-8.

Lakatos P, Caplice MD, Khanna V, Stern PH. Thyroid hormones increase insulin-like growth factor I content in the medium of rat bone tissue. J Bone Miner Res. 1993; 8:1475-81.

Lange M, Qvortrup K, Svendsen OL, Flyvbjerg A, Nowak J, Petersen MM, Sogaard K, FeldtRasmussen U. Abnormal bone collagen morphology and decreased bone strength in growth hormone-deficient rats. Bone. 2004; 35:178-85.

Lazar MA. Thyroid hormone receptors: multiple forms, multiple possibilities. Endocr Rev. 1993; 14:184-93.

Le Roith D, Bondy C, Yakar S, Liu JL, Butler A. The somatomedin hypothesis: 2001. Endocr Rev. 2001; 22:53-74.

Leung DW, Spencer SA, Cachianes G, Hammonds RG, Collins C, Henzel WJ, Barnard R, Waters MJ, Wood WI. Growth hormone receptor and serum binding protein: purification, cloning and expression. Nature. 1987; 330:537-43.

Lewinson D, Harel Z, Shenzer P, Silbermann M, Hochberg Z. Effect of thyroid hormone and growth hormone on recovery from hypothyroidism of epiphyseal growth plate cartilage and its adjacent bone. Endocrinology. 1989; 124:937-45.

Lewinson D, Shenzer P, Hochberg Z. Growth hormone involvement in the regulation of tartrate-resistant acid phosphatase-positive cells that are active in cartilage and bone resorption. Calcif Tissue Int. 1993; 52:216-21.

Lewinson D, Bialik GM, Hochberg Z. Differential effects of hypothyroidism on the cartilage and the osteogenic process in the mandibular condyle: recovery by growth hormone and thyroxine. Endocrinology. 1994; 135:1504-10.

Lindahl A, Isgaard J, Carlsson L, Isaksson OG. Differential effects of growth hormone and insulin-like growth factor I on colony formation of epiphyseal chondrocytes in suspension culture in rats of different ages. Endocrinology. 1987; 121:1061-9.

Liu JP, Baker J, Perkins AS, Robertson EJ, Efstratiadis A. Mice carrying null mutations of the genes encoding insulin-like growth factor I (Igf-1) and type 1 IGF receptor (Igf1r). Cell. 1993; 75:59-72. 
Lowe WL Jr, Roberts CT Jr, Lasky SR, LeRoith D. Differential expression of alternative 5' untranslated regions in mRNAs encoding rat insulin-like growth factor I. Proc Natl Acad Sci USA. 1987; 84:8946-50.

Lowe WL Jr, Lasky SR, LeRoith D, Roberts CT Jr. Distribution and regulation of rat insulinlike growth factor I messenger ribonucleic acids encoding alternative carboxyterminal Epeptides: evidence for differential processing and regulation in liver. Mol Endocrinol. 1988; 2:528-35.

Lupu F, Terwilliger JD, Lee K, Segre GV, Efstratiadis A. Roles of growth hormone and insulin-like growth factor 1 in mouse postnatal growth. Dev Biol. 2001; 229:141-62.

Manzano J, Morte B, Scanlan TS, Bernal J. Differential effects of triiodothyronine and the thyroid hormone receptor beta-specific agonist GC-1 on thyroid hormone target genes in the brain. Endocrinology. 2003; 144:5480-7.

Melmed S, Yamashita S. Insulin-like growth factor-I action on hypothyroid rat pituitary cells: suppression of triiodothyronine-induced growth hormone secretion and messenger ribonucleic acid levels. Endocrinology. 1986; 118(4): 1483-90.

Miura M, Tanaka K, Komatsu Y, Suda M, Yasoda A, Sakuma Y, Ozasa A, Nakao K. Thyroid hormones promote chondrocyte differentiation in mouse ATDC5 cells and stimulate endochondral ossification in fetal mouse tibias through iodothyronine deiodinases in the growth plate. J Bone Miner Res. 2002; 17:443-54.

Mohan S, Nakao Y, Honda Y, Landale E, Leser U, Dony C, Lang K, Baylink DJ. Studies on the mechanisms by which insulin-like growth factor (IGF) binding protein-4 (IGFBP-4) and IGFBP-5 modulate IGF actions in bone cells. J Biol Chem. 1995; 270:20424-31.

Morel G, Chavassieux P, Barenton B, Dubois PM, Meunier PJ, Boivin G. Evidence for a direct effect of growth hormone on osteoblasts. Cell Tissue Res. 1993; 273:279-86.

Mosekilde L, Melsen F. A tetracycline-based histomorphometric evaluation of bone resorption and bone turnover in hyperthyroidism and hyperparathyroidism. Acta Med Scand. 1978; 204:97-102.

Murphy WR, Daughaday WH, Hartnett C. The effect of hypophysectomy and growth hormone on the incorporation of labeled sulfate into tibial epiphyseal and nasal cartilage of the rat. J Lab Clin Med. 1956; 47:715-22. 
Nanto-Salonen K, Muller HL, Hoffman AR, Vu TH, Rosenfeld RG. Mechanisms of thyroid hormone action on the insulin-like growth factor system: all thyroid hormone effects are not growth hormone mediated. Endocrinology. 1993; 132:781-8.

Nishiyama K, Sugimoto T, Kaji H, Kanatani M, Kobayashi T, Chihara K. Stimulatory effect of growth hormone on bone resorption and osteoclast differentiation. Endocrinology. 1996; 137:35-41.

O'Shea PJ, Harvey CB, Suzuki H, Kaneshige M, Kaneshige K, Cheng SY, Williams GR. A thyrotoxic skeletal phenotype of advanced bone formation in mice with resistance to thyroid hormone. Mol Endocrinol. 2003; 17:1410-1424.

Ohlsson C, Nilsson A, Isaksson O, Bentham J, Lindahl A. Effects of tri-iodothyronine and insulin-like growth factor (IGF-I) on alkaline phosphatase activity, [3H]thymidine incorporation and IGF-I receptor mRNA in cultured rat epipheyseal chondrocytes. J Endocrinol. 1992; 135:115-23.

Ohlsson C, Nilsson A, Isaksson O, Lindahl A. Growth hormone induces multiplication of the slowly cycling germinal cells of the rat tibial growth plate. Proc Natl Acad Sci USA. 1992; 89:9826-30.

Olney RC. Regulation of bone mass by growth hormone. Med Pediatr Oncol. 2003; 41:22834.

Palmiter RD, Brinster RL, Hammer RE, Trumbauer ME, Rosenfeld MG, Birnberg NC, Evans RM. Dramatic growth of mice that develop from eggs microinjected with metallothioneingrowth hormone fusion genes. Nature. 1982; 300:611-5.

Pellizas CG, Coleoni AH, Costamagna ME, Di Fulvio M, Masini-Repiso AM. Insulin-like growth factor I reduces thyroid hormone receptors in the rat liver. Evidence for a feed-back loop regulating the peripheral thyroid hormone action. J Endocrinol. 1998; 158:87-95.

Powell-Braxton L, Hollingshead P, Warburton C, Dowd M, Pitts-Meek S, Dalton D, Gillett N, Stewart TA. IGF-I is required for normal embryonic growth in mice. Genes Dev. 1993; 7:2609-17.

Ray RD, Asling CW, Walker DG, Simpson ME, Li CH, Evans HM. Growth and differentiation of the skeleton in thyroidectomized-hypophysectomized rats treated with thyroxin, growth hormone, and combination. J Bone Joint Surg Am. 1954; 36-A:94-103. 
Reinecke M, Schmid AC, Heyberger-Meyer B, Hunziker EB, Zapf J.Effect of growth hormone and insulin-like growth factor I (IGF-I) on the expression of IGF-I messenger ribonucleic acid and peptide in rat tibial growth plate and articular chondrocytes in vivo. Endocrinology. 2000; 141 (8), 2847-53.

Ribeiro MO, Carvalho SD, Schultz JJ, Chiellini G, Scanlan TS, Bianco AC, Brent GA. Thyroid hormone-sympathetic interaction and adaptive thermogenesis are thyroid hormone receptor isoform-specific. J Clin Invest. 2001; 108:97-105.

Rinderknecht E, Humbel R. The amino acid sequence of human insulin-like growth factor I and its structural homology with proinsulin. FEBS Lett. 1978; 253:2769-2776.

Robey PG, Boskey AL. Extracellular Matrix and Biomineralization of Bone. In: Favus MJ, editor. Primer on the Metabolic Bone Diseases and Disorders of Mineral Metabolism. 5 ed. Washington: The American Society for Bone and Mineral Research; 2003. p. 1-8.

Robson H, Siebler T, Stevens DA, Shalet SM, Williams GR. Thyroid hormone acts directly on growth plate chondrocytes to promote hypertrophic differentiation and inhibit clonal expansion and cell proliferation. Endocrinology. 2000; 141:3887-97.

Rosen HN, Chen V, Cittadini A, Greenspan SL, Douglas PS, Moses AC, Beamer WG. Treatment with growth hormone and IGF-I in growing rats increases bone mineral content but not bone mineral density. J Bone Miner Res. 1995; 10:1352-8.

Salmon W, Daughaday WH. A hormonally controlled serum factor which stimulates sulfate incorporation by cartilage in vitro. J Lab Clin Med. 1957; 49:825-826

Saltó C, Kindblom JM, Johansson C, Wang Z, Gullberg H, Nordström K, Mansén A, Ohlsson C, Thorén P, Forrest D, Vennström B. Ablation of TRalpha2 and a concomitant overexpression of alpha1 yields a mixed hypo- and hyperthyroid phenotype in mice. Mol Endocrinol. 2001; 15:2115-28.

Schalch DS, Heinrich UE, Koch JG, Johnson CJ, Schlueter RJ. Nonsuppressible insulin-like activity (NSILA). I. Development of a new sensitive competitive protein-binding assay for determination of serum levels. J Clin Endocrinol Metab. 1978; 46:664-71.

Scheven BA, Hamilton NJ, Fakkeldij TM, Duursma SA. Effects of recombinant human insulin-like growth factor I and II (IGF-I/-II) and growth hormone (GH) on the growth of normal adult human osteoblast-like cells and human osteogenic sarcoma cells. Growth Regul. 1991; 1:160-7. 
Schmid C, Rutishauser J, Schlapfer I, Froesch ER, Zapf J. Intact but not truncated insulin-like growth factor binding protein-3 (IGFBP-3) blocks IGF I-induced stimulation of osteoblasts: control of IGF signalling to bone cells by IGFBP-3-specific proteolysis? Biochem Biophys Res Commun. 1991; 179:579-85.

Schmid C, Schlapfer I, Gosteli-Peter MA, Froesch ER, Zapf J. Effects and fate of human IGFbinding protein-5 in rat osteoblast cultures. Am J Physiol. 1996; 271:E1029-35.

Sims NA, Clement-Lacroix P, Da Ponte F, Boualin Y, Binart N, Moriggl R, Goffin V, Coschigano K, Gaillard-Kelly M, Kopchick J, Baron R, Kelly PA. Bone homeostasis in growth hormone receptor-null mice is restored by IGF-I but independent of Stat5. J Clin Invest. 2000; 106 (9):1095-103.

Sjogren K, Bohlooly YM, Olsson B, Coschigano K, Tornell J, Mohan S, Isaksson OG, Baumann G, Kopchick J, Ohlsson C. Disproportional skeletal growth and markedly decreased bone mineral content in growth hormone receptor -/- mice. Biochem Biophys Res Commun. 2000; 267:603-8.

Sjogren K, Sheng M, Movérare S, Liu JL, Wallenius K, Törnell J, Isaksson O, Jansson JO, Mohan S, Ohlsson C. Effects of liver-derived insulin-like growth factor I on bone metabolism in mice. J Bone Miner Res. 2002; 17:1977-87.

Slootweg MC, Most WW, van Beek E, Schot LP, Papapoulos SE, Lowik CW. Osteoclast formation together with interleukin-6 production in mouse long bones is increased by insulinlike growth factor-I. J Endocrinol. 1992; 132:433-8.

Slootweg MC, Salles JP, Ohlsson C, de Vries CP, Engelbregt MJ, Netelenbos JC. Growth hormone bind to a single high affinity receptor site on mouse osteoblastos: modulation by retinoic acid and cell differentiation. J Endocrionol. 1996; 150: 465-72.

Smeets T, Van Buul-Offers S. The influence of growth hormone, somatomedins, prolactin and thyroxine on the morphology of the proximal tibial epiphysis and growth plate of Snell dwarf mice. Growth. 1983; 47(2):160-73.

Stevens DA, Hasserjian RP, Robson H, Siebler T, Shalet SM, Williams GR. Thyroid hormones regulate hypertrophic chondrocyte differentiation and expression of parathyroid hormone-related peptide and its receptor during endochondral bone formation. J Bone Miner Res. 2000; 15(12):2431-42. 
Thorngren KG, Hansson LI. Effect of thyroxine and growth hormone on longitudinal bone growth in the hypophysectomized rat. Acta Endocrinol (Copenh). 1973; 74:24-40.

Thorngren KG, Hansson LI. I. Bioassay of growth hormone. II. Determination of longitudinal bone growth with tetracycline in thyroxine-treated hypophysectomized rats. Acta Endocrinol (Copenh). 1974; 75:669-682.

Trost SU, Swanson E, Gloss B, Wang-Iverson DB, Zhang H, Volodarsky T, Grover J, Baxter JD, Chiellini G, Scanlan TS, Dillmann WH. The thyroid hormone receptor-beta-selective agonist GC-1 differentially affects plasma lipids and cardiac activity. Endocrinology. 2000; 141:3057-64.

Tseng KF, Goldstein SA. Systemic over-secretion of growth hormone in transgenic mice results in a specific pattern of skeletal modeling and adaptation. J Bone Miner Res. 1998; 13:706-15.

Ueland T. Bone metabolism in relation to alterations in systemic growth hormone. Growth Horm IGF Res. 2004; 14:404-17.

Van Der Eerden BC, Karperien M, Wit JM. Systemic and local regulation of the growth plate. Endocr Rev. 2003; 24:782-801.

Van Erum R, Mulier M, Carels C, Verbeke G, De Zegher F. Craniofacial growth in short children born small for gestation age: effect of growth hormone treatment. J Dent Res. 1997; 76 (9): 1579-1586.

Vestergaard P, Weeke J, Hoeck HC, Nielsen HK, Rungby J, Rejnmark L, Laurberg P, Mosekilde L. Fractures in patients with primary idiopathic hypothyroidism. Thyroid. 2000; 10:335-40.

Watanabe H, Washizuka T, Komura S, Yoshida T, Hosaka Y, Hatada K, Aizawa Y, Chinushi M, Yamamoto T, Ma M, Watanabe K. Genomic and non-genomic regulation of L-type calcium channels in rat ventricle by thyroid hormone. Endocr Res. 2005; 31(1): 59-70.

Wikstrom L, Johansson C, Saltó C, Barlow C, Barros AC, Baas F, Forrest D, Thorén P, Vennström B. Abnormal heart rate and body temperature in mice lacking thyroid hormone receptor alpha 1. Embo J. 1998; 17:455-61.

Williams GR, Bland R, Sheppard MC. Characterization of thyroid hormone (T3) receptors in three osteosarcoma cell lines of distinct osteoblast phenotype: interactions among T3, vitamin D3, and retinoid signaling. Endocrinology. 1994; 135:2375-85. 
Woods KA, Camacho-Hubner C, Savage MO, Clark AJ. Intrauterine growth retardation and postnatal growth failure associated with deletion of the insulin-like growth factor I gene. $\mathrm{N}$ Engl J Med. 1996; 335:1363-7.

Yakar S, Rosen CJ, Beamer WG, Ackert-Bicknell CL, Wu Y, Liu JL, Ooi GT, Setzer J, Frystyk J, Boisclair YR, Le Roith D. Circulating levels of IGF-I directly regulate bone growth and density. J Clin Invest. 2002; 110 (6): 771-81.

Zhao G, Monier-Faugere MC, Langub MC, Geng Z, Nakayama T, Pike JW, Chernausek SD, Rosen CJ, Donahue LR, Malluche HH, Fagin JA, Clement TL. Targeted overexpression of insulin-like growth factor I to osteoblasts of transgenic mice: increased trabecular bone volume without increased osteoblast proliferation. Endocrinology. 2000; 141:2674-82. 